\author{
UNIVERSIDADE DE SÃO PAULO \\ FACULDADE DE CIÊNCIAS FARMACÊUTICAS \\ Programa de Pós-Graduação em Tecnologia Bioquímico- \\ Farmacêutica \\ Área de Tecnologia de Fermentações
}

\begin{abstract}
Produção, caracterização cinética e engenharia de proteína Asparaginase 1 de Saccharomyces cerevisiae para avaliação de seu uso como biofármaco
\end{abstract}

Iris Munhoz Costa

São Paulo

2015 


\author{
UNIVERSIDADE DE SÃO PAULO \\ FACULDADE DE CIÊNCIAS FARMACÊUTICAS \\ Programa de Pós-Graduação em Tecnologia Bioquímico- \\ Farmacêutica \\ Área de Tecnologia de Fermentações
}

\title{
Produção, caracterização cinética e engenharia de proteína Asparaginase 1 de Saccharomyces cerevisiae para avaliação de seu uso como biofármaco
}

\author{
Iris Munhoz Costa
}

Versão corrigida da Dissertação/Tese conforme resolução CoPGr 6018.

O original encontra-se disponível no Serviço de Pós Graduação da FCF/USP.

Dissertação para obtenção do Título de MESTRE.

Orientadora: Profa. Dra. Gisele Monteiro de Souza 
Ficha Catalográfica

Elaborada pela Divisão de Biblioteca e

Documentação do Conjunto das Químicas da USP.

\footnotetext{
Costa, Iris Munhoz

C837p Produção, caracterização cinética e engenharia de proteina Asparaginase 1 de Saccharomyces cerevisiae para avaliação de seu uso como biofármaco / Iris Munhoz Costa. -. São Paulo, 2014 .

$80 \mathrm{p}$.

Dissertação (mestrado) - Faculdade de Ciências Farmacêuticas da Universidade de São Paulo. Departamento de Tecnologia Bioquímico-Farmacêutica.

Orientador: Souza, Gisele Monteiro de

1. Enzima : Biotecnologia 2. Neoplasias I. T. II. Souza, Gisele Monteiro de, orientador.
}

620.8 CDD 
Iris Munhoz Costa

\title{
Produção, caracterização cinética e engenharia de proteína Asparaginase 1 de Saccharomyces cerevisiae para avaliação de seu uso como biofármaco
}

\author{
Comissão Julgadora \\ da \\ Dissertação para obtenção do grau de Mestre
}

Profa. Dra. Gisele Monteiro de Souza

Orientador/presidente

$1^{\circ}$. examinador

$2^{\circ}$. examinador

São Paulo, de de 2015. 
Dedico esta dissertação à minha mãe, Claudia, aos meus avós, Maria e Alcides, ao meu irmão, Danilo, e ao meu noivo, Anderson, que são meu exemplo, meu alicerce, meu norte. 


\section{AGRADECIMENTOS}

À Profa. Dra. Gisele Monteiro de Souza, pela oportunidade, pelos ensinamentos, compreensão, paciência ao longo desses anos. Foi quem me ensinou a amar, admirar e respeitar a ciência. Agradeço as palavras sábias 0 otimismo, carinho e amizade.

Aos meus colegas de laboratório (Mariane, Samarina, Débora, Karen, Mariana, Marcela, Beatriz, Lucas, Henrique, Rafaela, Bruna), a todos que em algum momento conviveram comigo e me ajudaram de alguma maneira.

À Marcela e à Karen que me ajudaram muito experimentalmente e me passaram um pouco dos seus conhecimentos.

Às alunas Mariana e Beatriz que me ajudaram com os ensaios.

Em especial à Marcela, à Débora, à Karen e à Mariana, pelas conversas, sessões de terapia, conselhos e risadas.

À minha família que sem eles nada disso seria possível.

À minha mãe simplesmente por existir. Por todo amor e carinho, por estar sempre ao meu lado me apoiando, por acreditar em mim, pela paciência e compreensão.

Ao meu irmão que esteve sempre ao meu lado me dando força, me apoiando, me ouvindo.

Aos meus amados avós por toda dedicação, amor e carinho. Sem eles, eu não teria chegado até aqui.

Ao meu noivo pelo companheirismo ao logo desses anos, por me escutar, me apoiar e estar sempre ao meu lado.

Gostaria de agradecer à Profa. Dra. Sandra H.P. Farsky, a técnica Paula e aos colegas do laboratório de toxicologia da FCF/USP, pelo ensino, ajuda e atenção com o cultivo de células.

Ao Prof. Dr. Marcos Antônio de Oliveira, da Unesp de São Vicente, e aos seus alunos pela ajuda com alguns experimentos.

À FAPESP (bolsa processo 2013/16685-2 vinculado ao projeto temático processo 2013/08617-7) pelo auxilio financeiro.

A todos, o meu muito obrigada! 
"De tudo ficaram três coisas...

A certeza de que estamos começando...

A certeza de que é preciso continuar...

A certeza de que podemos ser interrompidos antes de terminar...

Façamos da interrupção um caminho novo...

Da queda, um passo de dança...

Do medo, uma escada...

Do sonho, uma ponte...

Da procura, um encontro!" 


\section{RESUMO}

COSTA, I.M. Produção, caracterização cinética e engenharia de proteína Asparaginase 1 de Saccharomyces cerevisiae para avaliação de seu uso como biofármaco. 2015. Dissertação (Mestrado) - Faculdade de Ciências Farmacêuticas, Universidade de São Paulo, São Paulo, 2015.

A L-asparaginase (EC 3.5.1.1) é uma enzima importante para o tratamento da leucemia linfoblástica aguda (LLA), neoplasia mais frequente em crianças e adolescentes. A L-asparaginase hidrolisa a L-asparagina resultando em ácido aspártico e amônio, impedindo que as células tumorais utilizem esse aminoácido para síntese proteica, ocasionando a morte celular apoptótica. Atualmente a enzima é obtida a partir de Escherichia coli e Erwinia chrysanthemi; no entanto, ambas as formulações estão associadas a um alto índice de efeitos adversos que comprometem a evolução e eficácia do tratamento. A levedura Saccharomyces cerevisiae tem o gene ASP1 responsável pela produção de L-asparaginase 1 (Sc_ASPase1) que tem sido pouco estudada. Para elucidar as características de Sc_ASPase1 nós expressamos a proteína em E. coli BL21(DE3) e a purificamos por cromatografia de afinidade. Sc_ASPase1 tem uma atividade especifica de 195,4 U/mg para L-asparagina e de $0,36 \mathrm{U} / \mathrm{mg}$ para L-glutamina, e um comportamento alostérico com um $K_{0.5}$ de $75 \mu \mathrm{M}$ para L-asparagina. Por meio de mutação sitio dirigida demonstramos a importância dos resíduos Thr64Thy78-Th141-Lys215 para a catálise. As isoformas mutantes da proteína A331D, K335E, Y243S, S301N e $\Delta G 77$ não apresentaram melhoria nos parâmetros cinéticos ou atividade específica. Construímos e clonamos Sc_ASPase1 com a deleção dos primeiros 52 aminoácidos, porém nas condições testadas a proteína foi expressa na forma insolúvel. Demonstramos que Sc_ASPase1 possui potencial antineoplásico, pois com $10 \mathrm{U} / \mathrm{mL}$ de enzima foi capaz causar a $85 \%$ de mortalidade da linhagem leucêmica MOLT4. Na mesma concentração, a enzima de E. coli é capaz de matar $95 \%$ de células dessa mesma linhagem.

Palavras-chaves: L-asparaginase. Saccharomyces cerevisiae. Leucemia linfoblástica aguda. Engenharia de proteína. 


\section{ABSTRACT}

COSTA, I. M. Production, kinetic characterization and engineering of asparaginase 1 protein from Saccharomyces cerevisiae to evaluate its use as a biopharmaceutical. 2015. Dissertation (MSc) - Faculdade de Ciências Farmacêuticas, Universidade de São Paulo, São Paulo, 2015.

L-Asparaginase (EC 3.5.1.1) is an important enzyme for the treatment of acute lymphoblastic leukemia (ALL), the most common malignancy in children and adolescents. L-asparaginase hydrolyzes L-asparagine resulting in ammonium and aspartic acid, preventing tumor cells of using such amino acid for protein synthesis, leading to apoptotic cell death. Currently, the enzyme is obtained from Escherichia coli and Erwinia chrysanthemi; however, both formulations are associated with a high incidence of side effects that compromise the progress and effectiveness of treatment. The yeast Saccharomyces cerevisiae has ASP1 gene responsible for the production of L-asparaginase 1 (Sc_ASPase1) that has been poor studied. To elucidate the characteristics of Sc_ASPase1, we expressed the protein in E. coli BL21 (DE3) cells and purified it by affinity chromatography. Sc_ASPase1 has a specific activity of $195.4 \mathrm{U} / \mathrm{mg}$ for Lasparagine and $0.36 \mathrm{U} / \mathrm{mg}$ for L-glutamine, and an allosteric behavior with a $\mathrm{K}_{0.5}$ of $75 \mu \mathrm{M}$ for $\mathrm{L}$-asparagine. Through site directed mutation, we demonstrated the importance of Thr64-Thy78-Th141-Lys215 residues for catalysis. The mutant protein isoforms A331D, K335E, Y243S, S301N and $\Delta G 77$ showed no improvement in kinetic parameters or specific activity. We build and cloned Sc_ASPase 1 with the deletion of the first 52 amino acids, but under the conditions tested the protein was expressed in insoluble form. Sc_ASPase1 have demonstrated potential antineoplastic activityc, since 10 $\mathrm{U} / \mathrm{mL}$ of enzyme lead to $85 \%$ of mortality in leukemia cell line MOLT-4. At the same concentration, the E. coli enzyme kills $95 \%$ of the cells of the same line.

Keywords: L-asparaginase. Saccharomyces cerevisiae. Acute lymphoblastic Leukemia. Protein Engineering. 


\section{LISTA DE FIGURAS}

Figura 1 - Reação da hidrólise de L-asparagina e L-glutamina catalisada pela L-

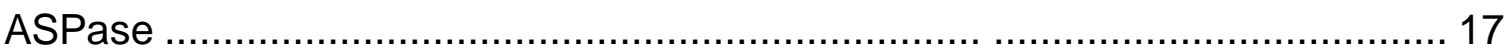

Figura 2 - Reação de transamidação mediada pela asparagina sintetase ......... 18

Figura 3 - Dois motivos conservados nas L-ASPases bacterianas .................... 22

Figura 4 - Estrutura da L-ASPase II de E. coli ............................................. 23

Figura 5 - Mecanismo de ação das L-asparaginases bacterianas ..................... 24

Figura 6 - Gel SDS-PAGE 14\% após a purificação de Sc_ASPase1 ................. 43

Figura 7 - Atividade específica de Sc_ASPase1 ......................................... 45

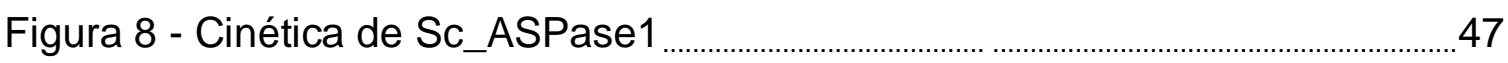

Figura 9 - Atividade específica de Sc_ASPase 1 com adição de L-aspartato ..... 51

Figura 10 - Alinhamento das sequências das enzimas L-asparaginases:

Resíduos mutados e estrutura teórica de Sc_ASPase1 ................................. 50

Figura 11 - Purificação e atividade das isoformas mutantes ............................. 52

Figura 12 - Purificação e atividade específica das isoformas mutantes ............. 55

Figura 13 - Alinhamento do inicio da sequencia de aminoácidos de Sc_ASPase1 com as enzimas bacterianas .................................................... 56

Figura 14 - Gel SDS-PAGE 14\% da expressão de Asp1p+53 em E. coli

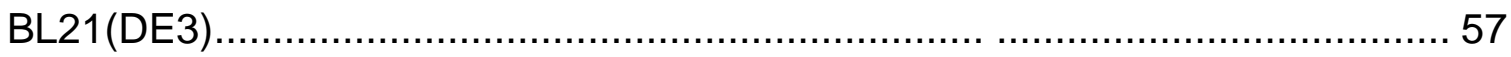

Figura 15 - Gel SDS-PAGE redutor 14\% da expressão de Asp1p+53 em E. coli BL21 (DE3)..... 68

Figura 16 - Gel SDS-PAGE redutor 14\% da purificação de Asp1p+53 em E. coli AD494, BL21pLysS (DE3), C43 (DE3), Rosetta (DE3), Origami (DE3) e Arctic (DE3) 60

Figura 17 - Citotoxicidade para células MOLT-4 das enzimas Sc_ASPase1 e Ec_ASPasell 61 


\section{LISTA DE TABELA}

Tabela 1 - L-ASPases comercialmente disponíveis 18

Tabela 2 - Porcentagem de identidade de sequência primária entre as enzima Sc_ASPase1, Ec_ASPase1 e Ec_ASPasell ............................................... 26

Tabela 3 - Iniciadores para mutação sítio dirigida............................................ 33

Tabela 4 - Condições de indução de Asp1p+53 ............................................ 36

Tabela 5 - Parâmetros cinéticos de Sc_ASPase1 e Ec_ASPasell comercial

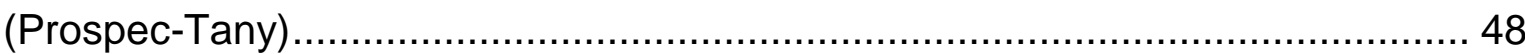

Tabela 6 - Parâmetros cinéticos das isoformas mutantes de Sc_ASPase1 .........56 


\section{LISTA DE ABREVIAÇÕES}

AEP

ANVISA

AMP

ASNS

ATP

DNA

DNTP

DTT

Ec_ASPasel

Ec_ASPasell

Er_ASPasell

Fiocruz

FW

$\mathrm{GDH}$

IMAC

INCA

IPTG

L-ASPase

L.B

LLA

MS

NAD ${ }^{+}$

$\mathrm{NADH}$

PCR

PEG

PPi

PSA

Rev

Sc_ASPase 1

SDS asparagina endopeptidase

Agencia Nacional de Vigilância Sanitária

adenosina monofosfato

asparagina sintetase

adenosina trifosfato

ácido desoxirribonucleico

desoxirribonucleotídeos fosfatados

ditiotreitol

L-asparaginase tipo I de Escherichia coli

L-asparaginase tipo II de Escherichia coli

L-asparaginase tipo II de Erwinia chrysanthemi

Fundação Oswaldo Cruz

forward

L- glutamato desidrogenase

cromatografia de afinidade a metal imobilizado

Instituto Nacional de Câncer

isopropil $\beta$-D-tiogalactopiranosídeo

L-asparaginase

meio de cultura Luria - Bertani

leucemia linfoblástica aguda

ministério da saúde

nicotinamida adenina dinucleotídeo oxidado

nicotinamida adenina dinucleotídeo reduzido

reação em cadeia da polimerase

polietilenoglicol

pirofosfato

persulfato de amônio

reverse

L-asparaginase 1 de Saccharomyces cerevisiae dodecil sulfato de sódio 
eletroforese em gel de poliacrilamida com dodecil sulfato de sódio

TAE

Tris, Ácido Acético e EDTA (ácido etilenodiamino tetraacético)

TEMED

$N, N, N^{\prime}, N^{\prime}$-Tetrametiletano-1,2-diamino

Tris- $\mathrm{HCl}$ trisaminometano hidrocloreto 


\section{LISTA DE SÍMBOLOS E UNIDADES}

\begin{tabular}{ll}
$\mu \mathrm{g}$ & micrograma \\
$\mu \mathrm{L}$ & microlitro \\
$\mu \mathrm{m}$ & micrometro \\
$\mathrm{Kb}$ & kilobase \\
$\mathrm{kV}$ & kilovolt \\
$g$ & aceleração gravitacional \\
$\mathrm{mL}$ & mililitro \\
$\mu \mathrm{g} / \mathrm{mL}$ & micrograma por mililitro \\
$\%$ & por cento \\
$\mu \mathrm{mol}$ & micromol \\
$\mu \mathrm{mol} / \mathrm{mL}$ & micromol por mililitro \\
$\mu \mathrm{mol} / \mathrm{min}$ & micromol por minuto \\
$\mathrm{M}$ & molar \\
$n_{H}$ & coeficiente de Hill \\
$\mathrm{U} / \mathrm{mg}$ & unidade por miligrama \\
$\mathrm{U} / \mu \mathrm{L}$ & unidade por microlitro \\
${ }^{\circ} \mathrm{C}$ & graus Celsius \\
$\mathrm{rpm}$ & rotação por minuto \\
$\mathrm{mg}$ & miligrama \\
$\mathrm{R}$ & coeficiente de correlação \\
$K_{\mathrm{m}}$ & constante de Michaelis-Menten \\
$K_{\mathrm{cat}}$ & constante catalítica \\
$\mathrm{V}_{\mathrm{máx}}$ & velocidade máxima \\
$\mathrm{pmol} / \mu \mathrm{L}$ & picomol por microlitro \\
$\mathrm{kDa}$ & quilo Dalton \\
\hline $\mathrm{m}$ & coeficiente de extinção molar
\end{tabular}




\section{SUMÁRIO}

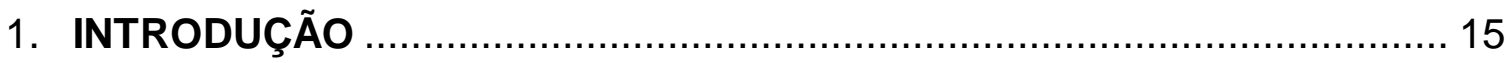

1.1 Leucemia Linfoblástica Aguda ....................................................... 15

1.2 A L-asparaginase II (L-ASPase) no tratamento da LLA ......................... 16

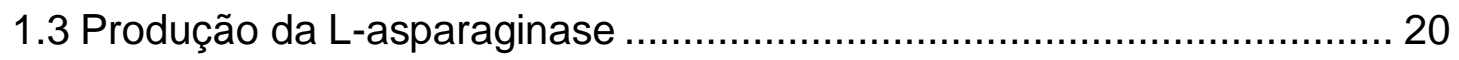

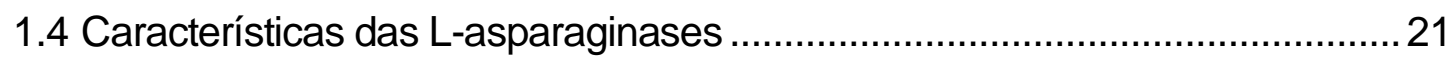

1.5 Produção de L-ASPase por diferentes microrganismos ......................... 25

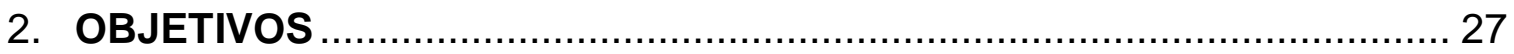

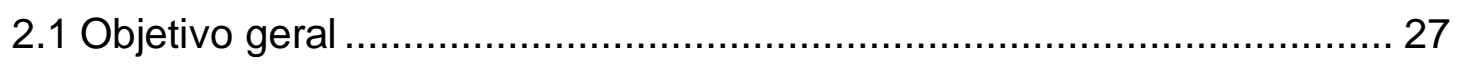

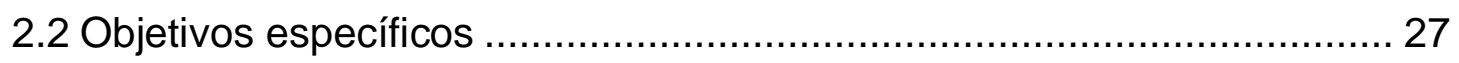

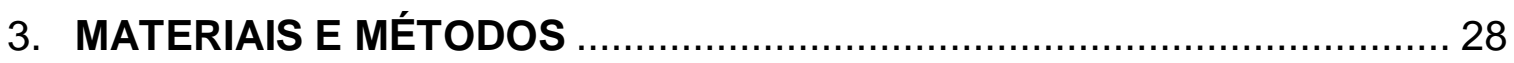

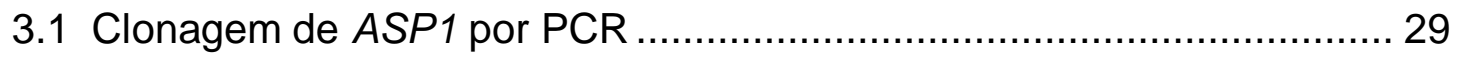

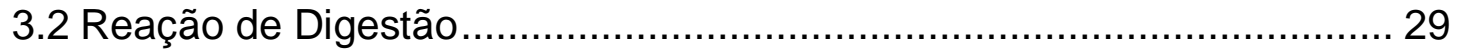

3.3 Purificação de Produtos de digestão .................................................. 30

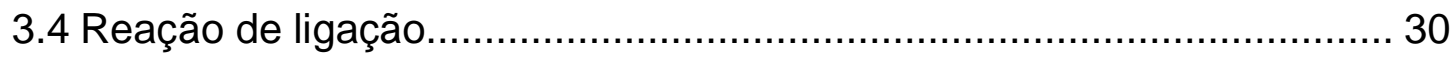

3.5 Transformação em Escherichia coli ................................................... 30

3.6 Mini-Preparação de Plasmídeos (miniprep) ………………….............. 31

3.7 Construção e clonagem de ASP1 truncada (Asp1p+53) .......................... 31

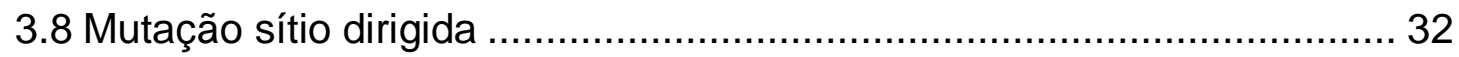

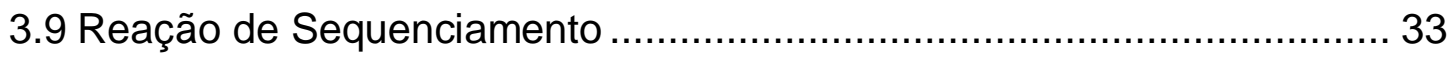

3.10 Expressão e Purificação de proteína por cromatografia de afinidade a metais (níquel) - IMAC ..................................................................... 34

3.10.1 Sc_ASPase1 selvagem e Isoformas mutantes .......................... 34

3.10.2 Sc_ASPase1 truncada (Asp1p+53) ........................................ 35

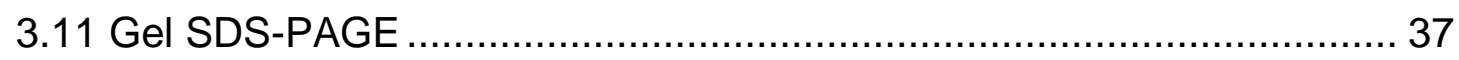

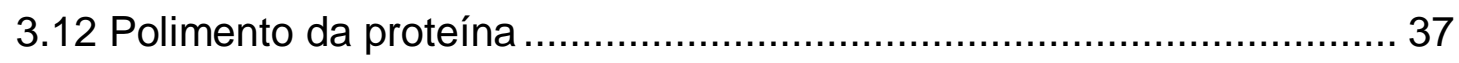

3.13 Determinação da Atividade Específica e Parâmetros Cinéticos............. 38

3.13.1 Determinação da Atividade específica ........................................... 39

3.13.2 Determinação dos Parâmetros Cinéticos .......................................... 40

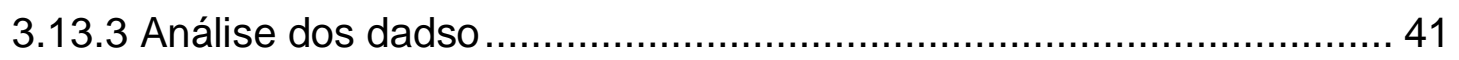

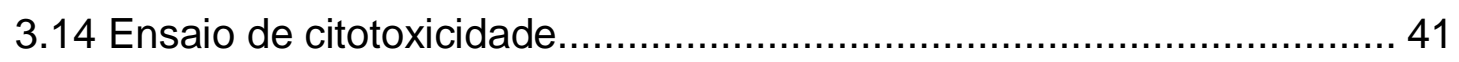

4. RESULTADOS 
4.1 Obtenção e determinação dos parâmetros cinéticos de Sc_ASPase 1.... 43

4.2 Mutações em Sc_ASPase1 ........................................................... 49

4.2.1 Caracterização do sítio catalítico ............................................ 49

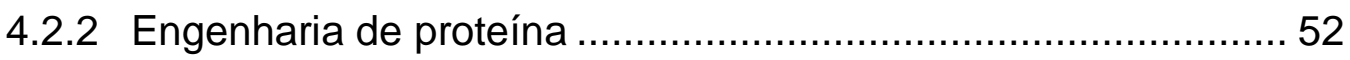

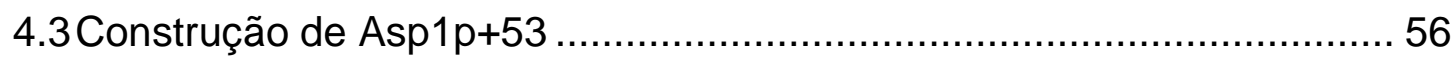

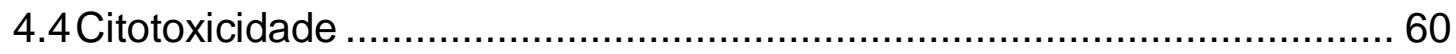

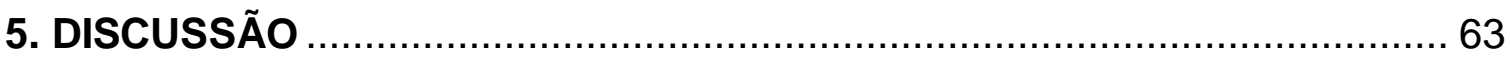

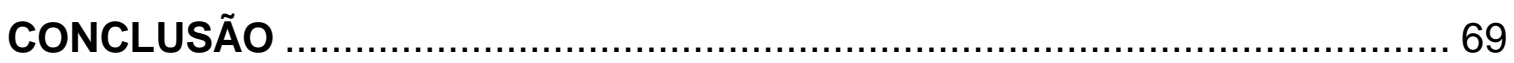

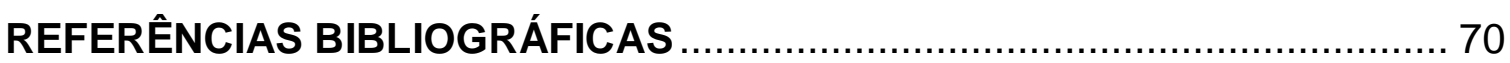

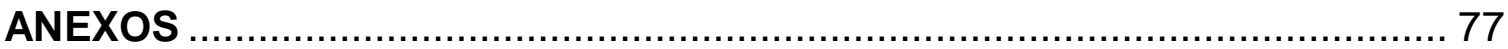




\section{INTRODUÇÃO}

\subsection{Leucemia Linfoblástica Aguda}

A leucemia linfoblástica/ linfocítica aguda (LLA) se desenvolve a partir dos linfócitos primitivos, que podem se encontrar em diferentes estágios de desenvolvimento. Resulta da proliferação descontrolada de blastos de características linfoides, os quais se acumulam na medula óssea ou em locais extra medulares, e no bloqueio da hematopoese normal (HAMERSCHLAK, 2008; DAVIS, VIEIRA e MEAD, 2014).

A LLA é uma neoplasia predominante em crianças e adolescentes, com incidência quase duas vezes mais comum em indivíduos brancos do que em não caucasianos, sendo ligeiramente mais frequente no sexo masculino do que no feminino. A LLA também ocorre em adultos de todas as idades, porém com menos frequência (ROBBINS, KUMAR e COTRAN, 2000).

A etiologia da LLA é desconhecida, mas alguns fatores genéticos e de risco ambiental estão associados a uma maior predisposição a patologia (SILVA, 2009). Desta forma, a susceptibilidade genética é considerado um fator de risco importante para o desenvolvimento da LLA (BRISSON, ALVES e POMBO-DE-OLIVEIRA, 2015; ROBERTS e MULLIGHAN, 2015).

Aproximadamente $85 \%$ das LLA consistem em tumores de células pré-B (linfócitos precursores B), enquanto as LLA de células pré-T (linfócitos precursores T) são menos comuns (ROBBINS, KUMAR e COTRAN, 2000). Os tipos B e T são divididos em subtipos, que estão relacionados com a expressão de diferentes antígenos em sua superfície, o grau desenvolvimento da linhagem celular, translocações cromossômicas e mutações (HOELZER, 2015; ROBERTS e MULLIGHAN, 2015). O diagnóstico da doença é feito, principalmente, da imunofenotipagem que separa as linhagens percursoras de células-B e células- $T$. As técnicas de citogenética, hibridização e reação em cadeia da polimerase são utilizadas para detectar cromossomo philadelphia positivo $\left(\mathrm{Ph}^{+}\right)$, translocações e deleções no DNA que estão associados à leucemia (HOELZER, 2015). 
Dentre as leucemias, a LLA é a neoplasia mais comum correspondendo a aproximadamente $80 \%$ dos casos de leucemia na América do Norte, Oceania e Europa (BRAGA, LATORRE, CURADO, 2002; WORLD HEALTH ORGANIZATION, 2009). Segundo a Leukemia and Lymphoma Society (2014), nos Estados Unidos são esperados 6.250 novos casos de LLA e 1.450 mortes para o ano de 2015. No Brasil foram estimados 11.370 novos casos de leucemia para 2014, e foram registradas 6.187 mortes por leucemia no ano de 2011 (INCA, 2014).

Com o tratamento adequado a taxa de remissão completa da doença em cinco anos é de $80 \%$ a 90\% dos casos (HOELZER, 2015; ROBERTS e MULLIGHAN, 2015). No entanto, ainda é a principal causa de morte relacionada ao câncer em crianças e jovens adultos (ROBERTS e MULLIGHAN, 2015). Em adultos, faixa etária de menor incidência de LLA, a taxa de cura é de apenas $35 \%$ a $44 \%$. A menor eficácia do tratamento acontece nessa faixa etária, pois o aumento da idade muda a taxa de depuração dos medicamentos no organismo, e isso altera o perfil de toxicidade (BURKE e DOUER, 2014).

O tratamento consiste de uma poliquimioterapia, composta por: Lasparaginase (L-ASPase), vincristina, metotrexato ou uma antraciclina, e um corticoide (prednisona ou dexametasona) (KUMAR et al., 2014). Dentre os medicamentos utilizados, a L-asparaginase é um agente fundamental no tratamento da LLA (BURKE e DOUER, 2014; KAWEDIA e RYTTING, 2014).

\subsection{A L-asparaginase II (L-ASPase) no tratamento da LLA}

Em 1953, Kidd demonstrou em ratos que a administração do soro de guinea pig (cobaia porco da Índia) resultava na remissão de linfomas transplantados. Em 1961, Broome analisou o soro de guinea pig e identificou a proteína responsável pela remissão do tumor, a L-ASPase. Em 1964, Mashburn e Wriston demonstraram que a L-ASPase obtida de Escherichia coli também possuia atividade antitumoral e desde 1970, essa enzima tornou-se 
um componente essencial na quimioterapia para o tratamento de LLA infantil (PIETERS et al., 2008; CORTIJO-CASCAJARES et al., 2012).

A L-ASPase é uma enzima que catalisa a hidrólise de L-asparagina em ácido aspártico e amônio, e que pode ter uma atividade residual para hidrólise de L-glutamina em ácido glutâmico e amônio (figura 1). Muitos blastos de leucemia e células da medula não têm ou possuem baixos níveis de asparagina sintetase (ASNS), por isso a asparagina fornecida pelo meio extracelular para produção de proteínas contribui de forma essencial para 0 crescimento de células tumorais (NARTA et al., 2007; RAETZ e SALZER, 2010).<smiles>NC(=O)CC(N)C(=O)O</smiles>

Asparagina<smiles>NC(=O)CCC(N)C(=O)O</smiles>

Glutamina<smiles>NC(CC(=O)O)C(=O)O</smiles>

Ácido Aspártico

L-Asparaginase<smiles>NC(CCC(=O)O)C(=O)O</smiles>

Ácido Glutâmico

Figura 1 - Reação de hidrólise da L-asparagina e L-glutamina catalisada pela L-ASPase.

No entanto, somente a depleção de L-asparagina pode não ser suficiente para causar a citotoxicidade nas células tumorais. A atividade glutaminásica da enzima tem sido descrita como importante para eficácia do tratamento (OFFMAN et al., 2011; AVRAMIS, 2012; EMADI et al., 2014). Algumas linhagens tumorais são capazes de expressar ASNS. Essas linhagens podem produzir L-asparagina por meio de uma reação de transamidação utilizando a L-glutamina como substrato (figura 2) (EMADI et al., 2014). 
<smiles>NC(=O)CCC(N)C(=O)O</smiles>
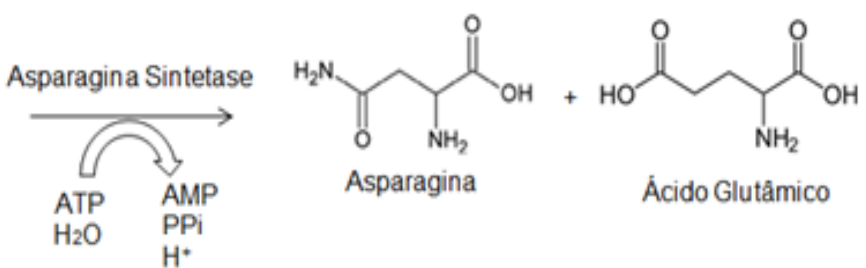

Figura 2 - Reação de transamidação mediada pela asparagina sintetase. Adaptado de Emadi et al., (2014).

As L-ASPases comercialmente disponíveis para o tratamento de LLA são enzimas do tipo II obtidas a partir das bactérias Escherichia coli (Ec_ASPasell) e Erwinia chrysanthemi (também nomeada de Dickeya chrysanthemi) (Er_ASPasell), ambas possuem atividade asparaginásica e glutaminásica. Atualmente, existem diferentes formulações derivadas dessas bactérias com propriedades distintas (PIETERS et al., 2008; CORTIJOCASCAJARES et al., 2012; KUMAR et al., 2014). Essas formulações estão relacionadas na tabela 1 .

Tabela 1 - L-ASPases comercialmente disponíveis*.

\begin{tabular}{|c|c|c|c|}
\hline Medicamento & Bactéria & Características & Vantagens \\
\hline Elspar $^{(}$ & $\begin{array}{l}\text { Escherichia } \\
\text { coli }\end{array}$ & Enzima nativa & $\begin{array}{l}\text { Primeira linha de } \\
\text { tratamento; }\end{array}$ \\
\hline Kidrolase $^{\circledR}$ & $\begin{array}{l}\text { Escherichia } \\
\text { coli }\end{array}$ & Enzima nativa & $\begin{array}{l}\text { Primeira linha de } \\
\text { tratamento; }\end{array}$ \\
\hline $\begin{array}{c}\text { Oncaspar }^{\circledR} \\
\text { (Peg- } \\
\text { asparaginase) }\end{array}$ & $\begin{array}{c}\text { Escherichia } \\
\text { coli }\end{array}$ & $\begin{array}{l}\text { Ligações covalentes } \\
\text { de unidades de } \\
\text { polietilenoglicol (PEG) } \\
\text { a enzima }\end{array}$ & $\begin{array}{c}\text { Maior meia vida } \\
\text { sérica; } \\
\text { Menos efeitos } \\
\text { adversos em relação } \\
\text { à nativa; }\end{array}$ \\
\hline Graspa $^{\circledR}$ & $\begin{array}{l}\text { Escherichia } \\
\text { coli }\end{array}$ & $\begin{array}{l}\text { Encapsulada dentro } \\
\text { de eritrócitos }\end{array}$ & $\begin{array}{l}\text { Aumenta a tolerância } \\
\text { ao tratamento; }\end{array}$ \\
\hline Leunase $^{\circledR}$ & $\begin{array}{c}\text { Escherichia } \\
\text { coli }\end{array}$ & $\begin{array}{l}\text { Obtida a partir da } \\
\text { cepa modificada HAP } \\
\text { (alta produção de } \\
\text { asparaginase) }\end{array}$ & $\begin{array}{l}\text { Efeito superior na } \\
\text { remissão de LLA; } \\
\text { Não possui } \\
\text { resistência cruzada } \\
\text { com outros } \\
\text { medicamentos; }\end{array}$ \\
\hline Erwinase $^{\Theta}$ & $\begin{array}{c}\text { Erwinia } \\
\text { chrysanthemi }\end{array}$ & Enzima nativa & $\begin{array}{l}\text { Menos efeitos } \\
\text { adversos em relação } \\
\text { à nativa de } E \text {. coli. }\end{array}$ \\
\hline Crisantaspase $^{\circledR}$ & $\begin{array}{c}\text { Erwinia } \\
\text { chrysanthemi }\end{array}$ & Enzima nativa & $\begin{array}{c}\text { Menos efeitos } \\
\text { adversos em relação } \\
\text { à nativa de } E \text {. coli. }\end{array}$ \\
\hline
\end{tabular}

*PIETERS et al., 2008; CORTIJO-CASCAJARES et al., 2012; KUMAR et al., 2014 
Apesar da variedade de formulações existentes no mercado, a LASPase apresenta uma alta incidência de efeitos adversos que comprometem a eficácia do tratamento. A L-ASPase pode induzir resposta imune, produzindo anticorpos anti-asparaginase. Estes são as principais causas de resistência ao medicamento resultando na redução da sua eficácia (NARAZAKI et al., 2012; AVRAMIS, 2012; KUMAR et al., 2014).

Além disso, a degradação de L-ASPase pelas proteases lisossomais catepsina $B$ e asparagina endopeptidase (AEP), que são produzidas por linfoblastos, resulta na sua inativação e exposição de epítopos e consequente ativação da resposta imune (OFFMAN et al., 2011).

A presença de anticorpos tem sido associada a reações de hipersensibilidade em aproximadamente $60 \%$ dos pacientes que fazem uso da enzima derivada de E. coli (PIETERS et al., 2011; ASSELIN e RIZZARI, 2015). Os sintomas incluem urticária, erupções, prurido, eritema, edema, bronco espasmos, hipotensão e, ocasionalmente, choque anafilático (NARAZAKI et al., 2012; AVRAMIS, 2012; KUMAR et al., 2014). Porém, essa hipersensibilidade pode ser assintomática, denominada inativação silenciosa, o que ocorre em $29 \%$ dos pacientes (ASSELIN e RIZZARI, 2015).

Geralmente, os pacientes que apresentam hipersensibilidade, por algum tipo de formulação, mudam para outro tipo para garantir a eficácia no tratamento (PIETERS et al., 2011; ASSELIN e RIZZARI, 2015). A PEGasparaginase possui menor imunogenicidade se comparada à enzima nativa. Entretanto, é comprovada a existência de reação-cruzada entre anticorpos produzidos contra L-ASPase nativa e PEG-asparaginase, tornando a troca uma opção inviável. A alternativa quando há reações às duas formulações é substituir por Erwinase ${ }^{\circledR}$ que não apresenta reação-cruzada. Apesar de possuir menos epítopos do que a enzima de E. coli e, consequentemente, possuir menor imunogenicidade, aproximadamente $33 \%$ dos pacientes ainda apresentarem reações alérgicas (PIETERS et al. 2011; RIZZARI et al., 2013).

Outros efeitos adversos são relatados, como: disfunção hepática, alterações na coagulação sanguínea, diarreia, vômito, pancreatite, supressão da medula óssea, baixos níveis séricos de antitrombina III e fibrinogênio, hiperglicemia (NARAZAKI et al., 2012; AVRAMIS, 2012; KUMAR et al. 2014). A ausência de L-glutamina e os produtos da hidrólise desse aminoacido e da L- 
asparagina resultam em hiperamonemia - causada pelo excesso de amônia na corrente sanguinea - são responsáveis pela neurotoxicidade do medicamento (depressão, letargia, fadiga, sonolência, confusão, irritabilidade, tontura, agitação, coma) presente em até $25 \%$ dos pacientes (NARTA et al., 2007; RAETZ e SALZER, 2010).

Em adultos, embora a L-ASPase esteja incluída na maioria dos protocolos, a incidência de efeitos adversos é maior do que em crianças e jovens adultos. A sua utilização tem sido mais limitada e menos minuciosamente estudada, principalmente devido a preocupações relacionadas com o aumento da toxicidade (DOUER, 2008; BURKE e DOUER, 2014).

\subsection{Produção da L-asparaginase}

A L-ASPase foi desenvolvida há mais de 40 anos e seu processo de produção é ineficiente e desatualizado. Essas preparações possuem cerca de $20 \%$ de agregados, os quais podem ser mais imunogênicos do que a própria enzima. Nas últimas décadas, a produção ineficiente levou a vários períodos de escassez de oferta desse fármaco essencial. Além disso, a contaminação com agregados tem impedido a aprovação destas preparações em vários países (PIETERS et al., 2008).

No Brasil existem diferentes protocolos oncológicos para o tratamento de LLA que variam conforme a classificação no grupo de risco, mas todos incluem a LASPase no tratamento (CONDUTAS DO INCA/MS, 2001; CONDUTAS DO INCA/MS, 2002). Segundo o portal da Agencia Nacional de Vigilância Sanitária (ANVISA) a única formulação com registro para comercialização e fabricação é a L-ASPase nativa advinda de E. coli. No entanto, a empresa internacional responsável pelo abastecimento brasileiro do medicamento anunciou a interrupção da fabricação em 2013. Diante desse quadro, faz-se necessário a busca por alternativas nacionais de abastecimento da L-ASPase. Para suprir a falta da enzima, a Fundação Oswaldo Cruz (Fiocruz) firmou parcerias com laboratórios privados para iniciar a produção nacional da L-ASPase nativa (MINISTÉRIO DA SAUDE, 2013). 
Os problemas na produção e comercialização desse medicamento, essencial para o tratamento da LLA, e a alta incidência de efeitos adversos causados pela enzima bacteriana fazem com que haja um grande interesse da comunidade científica por fontes alternativas de L-ASPase (SHRIVASTAVA et al., 2015).

\subsection{Características das L-asparaginases}

As L-ASPases (L-asparagina amidohidrolase EC 3.5.1.1) são classificadas em três famílias: do tipo Rhizobium etli são enzimas termolábeis induzidas por asparagina e repressão de carbono ; as do tipo planta são L-ASPases com baixa afinidade por para L-asparagina e possuem $60 \%$ de similaridade com aspartilglucosaminidases; e as do tipo bacteriana, que são subdividas em tipo I e tipo II (BOREK e JASKÓLSLI, 2001).

A classificação do tipo bacteriana é baseada nas L-ASPases tipo I e II de $E$. coli, que são expressas pelos genes ans $A$ e asnB, respectivamente. A enzima do tipo I é localizada no citosol, expressa constitutivamente e possui baixa afinidade por para L-asparagina e sem atividade antitumoral, enquanto a tipo II é periplasmática, induzida por anaerobiose, possui alta afinidade pelo substrato e apresenta atividade antitumoral (SCHWARTZ, REEVES e BROOME, 1966; CEDAR e SCHWARTZ, 1967; CASALE, SOLLITI e CHESNEY, 1983).

Em E. coli a L-ASPase do tipo I (Ec_ASPasel) foi caracterizada como um tetrâmero em que cada monômero possui $37,1 \mathrm{kDa}$, alostérica com baixa afinidade pela L-asparagina com um $K_{0,5}$ de $1,2 \mathrm{mM}$ e sem atividade glutaminásica descrita (YUN et al. 2007). Em E. chrysanthemi o gene ansA foi inferido por homologia como codificador para Er_ASPasel, mas sem dados experimentais comprobatórios (http://www.uniprot.org/uniprot/E0SBC5).

As L-ASPases do tipo II de E. coli (Ec_ASPasell) e E. chrysanthemi (Er_ASPasell) são as enzimas utilizadas no tratamento da LLA. Essas enzimas são codificadas pelo gene ansB, são homotetrâmeros funcionais, com alta afinidade pelo substrato L-asparagina. Ec_ASPasell possui $35,6 \mathrm{kDa}$ por subunidade (SWAIN et al., 1993) um $K_{\mathrm{m}}$ entre 12 e 15 MM (BROME, 1968; 
DERST, HENSELING e RÖHM, 2000; NARTA et al. 2007); Er_ASPasell possui 37,5 kDa (MILLER et al. 1993; AGHAIYPOUR, WLODAWER e LUBKOWSKI, 2001a) e um $K_{\mathrm{m}}$ entre 29 e $58 \mu \mathrm{M}$ (KOTZIA e LABROU, 2007; GERVAIS e FOOTE, 2014). Já para L-glutamina a afinidade é baixa, com um $K_{\mathrm{m}}$ de $3,5 \mathrm{mM}$ e 6,7 mM para Ec_ASPasell e Er_ASPasell, respectivamente (DERST, HENSELING e RÖHM, 2000; KOTZIA e LABROU, 2007).

Assim como a classificação, o mecanismo de ação das L-ASPases é conhecido pela caracterização da enzima Ec_ASPasell. As L-ASPases possuem dois motivos de aminoácidos altamente conservados (figura 3) (BOREK e JASKÓLSLI, 2001), os quais contêm as duas treoninas que participam da catálise (SWAIN et al. 1993; MILLER et al. 1993; PALM et al. 1996; AGHAIYPOUR, WLODAWER e LUBKOWSKI, 2001a).

3 -

$$
\begin{aligned}
& \text { Primeiro motivo } X_{1}-X_{1}-T-G-G-T-X_{2}-X_{3} \\
& \text { Segundo motivo: } X_{1}-X_{1}-H-G-T-D-T-X_{1}
\end{aligned}
$$

Figura 3 - Dois motivos conservados nas L-ASPases. O asterisco $\left(^{*}\right)$ indica as duas treoninas que participam da catálise. As possibilidades que $X$ pode assumir: $X_{1}$ pode assumir L-I-V-M; $X_{2}$ pode assumir I-V; e $X_{3}$ pode assumir A-G-S. Adaptado de Borek e Jaskólsli, 2001.

Os aminoácidos participantes do sítio ativo em Ec_ASPasell são T12, N24, Y25, S58, Q59, T89, D90, A114, K162, N248 e E283. O sítio ativo da enzima está localizado na interface de duas subunidades $A C$ e $B D$, e é constituído por resíduos de ambas (SWAIN et al. 1993; PALM et al. 1996), como mostra a figura 4. 


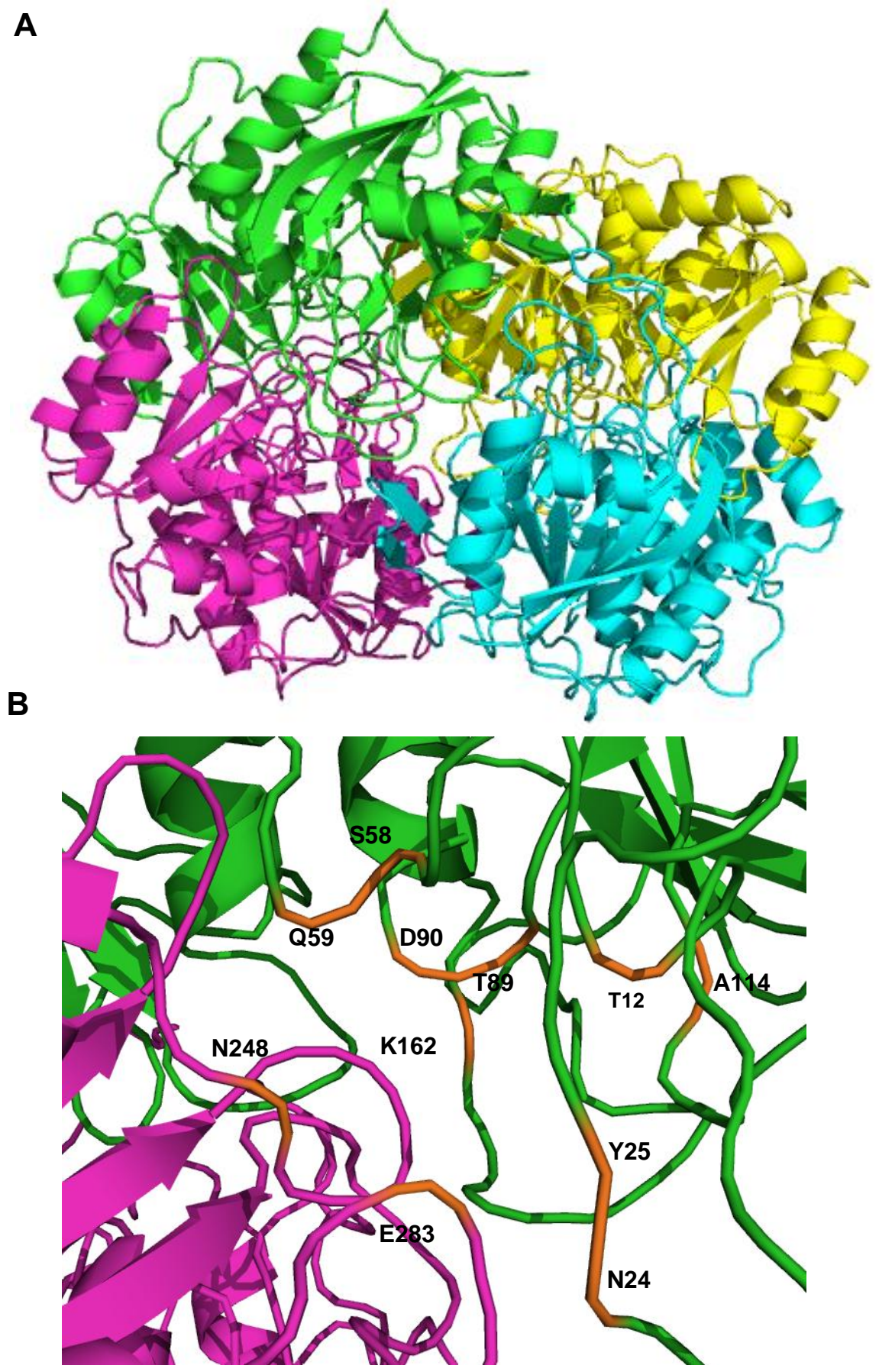

Figura 4 - Estrutura da Ec_ASPasell. Estrutura 3ECA obtida do Protein Data Bank (http://www.rcsb.org/pdb/explore/explore.do?structureld=3ECA). Imagem construída com 0 programa PyMOL. A: Homotetrâmero composto pela subunidade $A$ em verde, B em azul, $C$ em rosa e D em amarelo. B: Sítio ativo da enzima localizado na interface da subunidade $A$ (verde) e C (rosa); em laranja estão representados os resíduos constituintes do sítio ativo. Os resíduos T12, N24, Y25, S58, Q59, T89, D90, A114 e K162 fazem parte da subunidade A e os resíduos N248 e E283 fazem parte da subunidade $C$.

O mecanismo de ação proposto para as L-ASPases bacterianas é o primeiro ataque nucleofílico feito pelo resíduo T12 no grupo carboxiamida da cadeia lateral do aminoácido, seguido da liberação de amônia e formação de 
um intermediário acil-enzima, isto é, um intermediário catalítico no qual o substrato está ligado covalentemente à enzima. No passo subsequente, esse intermediário sofre um segundo ataque nucleofílico por uma molécula de água na ligação éster formada pelo carbono da carbonila e a enzima, resultando na hidrólise do intermediário acil-enzima produzindo o ácido aspártico, deixando a enzima livre (figura 5). Os resíduos K162 e T89 participam da transferência de prótons durante 0 segundo ataque nucleofílico feito pela molécula de água (PALM et al., 1996). A ligação do substrato no sítio ativo e o início da catálise só é possível com a estabilização e orientação correta do loop feita pela ligação de hidrogênio entre a Y25 e a T12 (AUNG et al., 2000).

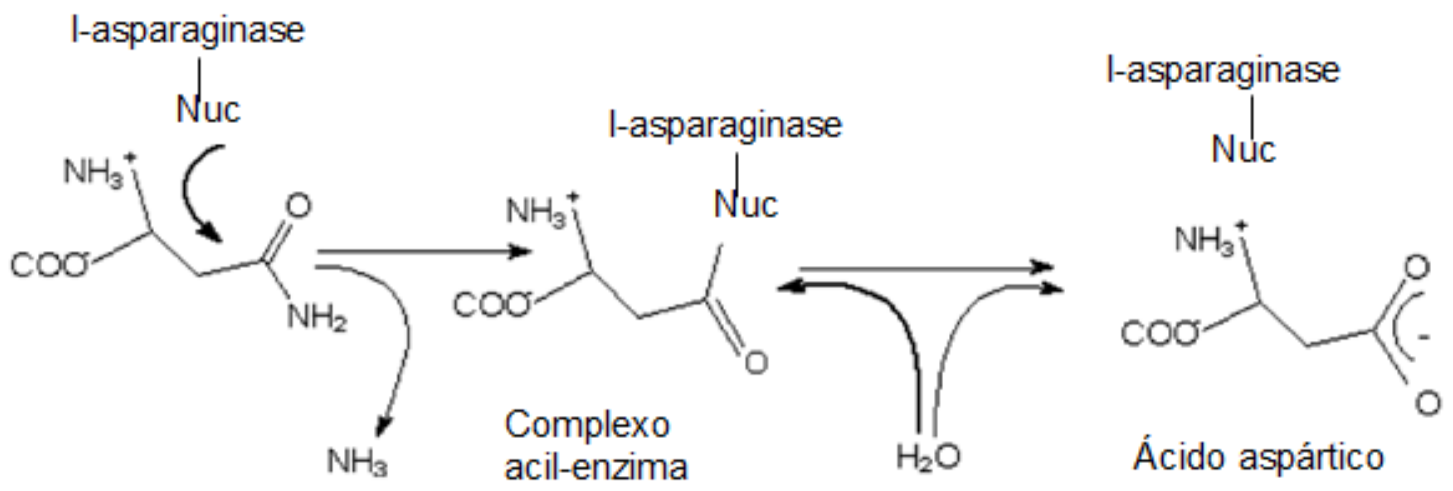

Figura 5 - Mecanismo de ação das L-asparaginases bacterianas. Formação do complexo intermediário após o ataque nucleofílico da enzima e um segundo ataque nucleofílico da molécula de água. Adaptado de Verma et al., (2007).

GESTO et al. (2013) propuseram em modelos teóricos baseados em dinâmica molecular, que 0 ataque nucleofílico ao substrato ocorreria pela molécula de água antes da liberação de amônia, formando um intermediário tetraédrico não-covalente. Desta forma, a tríade T12-K162-D90 agiria na desprotonação de uma molécula de água e, subsequentemente, se ligaria ao substrato; já a tríade T12-Y25-E283 atuaria na estabilização do intermediário tetraédrico formado após o ataque nucleofílico da molécula de água ao substrato. K162 receberia um próton da molécula de água que seria transferido para T89 e em seguida para o substrato, resultando na formação de amônia. 0 último passo da reação liberaria a amônia da molécula e o produto ácido, deixando a enzima pronta para outro ciclo catalítico.

Recentemente houve uma terceira proposta de mecanismo de ação, a qual sugere que o próprio substrato é o responsável pelo inicio da catálise. A 
transferência de prótons entre T89 e K162 faria com que o grupo carboxila da asparagina funcionasse como uma base, sendo o aceptor de prótons; essa protonação do substrato ativaria a T12. O ataque nucleofílico seria feito pelo oxigênio hidroxila da T12 no carbono y do aminoácido, formando um complexo intermediário covalente enzima-substrato que é estabilizado pela ligação de S58, o qual impediria o refluxo de prótons para T12 (ANISHKIN et al., 2015).

Baseado na Ec_ASPasell, sabe-se que os resíduos T12, T89, K162 são essenciais para a catálise. No entanto, o mecanismo de catálise das LASPases é ainda quimicamente indefinido.

\subsection{Produção de L-ASPase por diferentes microrganismos}

Imada et al. (1973) demonstraram que diferentes microrganismos, bactérias, fungos e leveduras, são capazes de produzir L-asparaginase e Lglutaminase. Entre as L-ASPases bacterianas, vegetais e humanas existem resíduos conservados (BOREK e JASKÓLSLI, 2001; KARAMITROS e KONRAD, 2014). No entanto, para ser considerada uma enzima com potencial efeito antineoplásico é necessário que a enzima seja altamente ativa em baixas concentrações de substrato e mantenha baixos os níveis séricos de Lasparagina (BROOME, 1968).

Em Saccharomyces cerevisiae ocorre a produção de duas L-ASPases, a L-asparaginase 1, expressa pelo gene ASP1 (YDR321W) e a L-asparaginase 3 expressa pelo gene ASP3. A proteína Asp1p (Sc_ASPase1) é encontrada no citosol da levedura, enquanto a isoforma codificada pelo gene ASP3 é secretada. Todas hidrolisam L-asparagina, mas são bioquímica e geneticamente distintas (DUNLOP et al., 1978; SINCLAR, WARNER e BONTHRON, 1994).

As isoformas produzidas por $S$. cerevisiae são classificadas, por similaridade na sequencia de aminoácidos, como pertencentes à família bacteriana do tipo II (BONTHRON e JASKÓLSLI, 1997; BOREK e JASKÓLSLI, 2001), mesmo Sc_ASPase1 sendo citosólica e apresentado uma baixa afinidade pelo substrato na sua primeira caracterização, na década de 70 
(JONES e MORTIMER, 1973; DUNLOP, et al. 1978). É possível observar que o percentual de identidade entre Sc_ASPase1 e Ec_ASPasell é maior do que quando comparado com Ec_ASPasel (tabela 2).

Tabela 2 - Porcentagem de identidade de sequência primária entre as enzima Sc_ASPase1, Ec_ASPase1 e Ec_ASPasell.

\begin{tabular}{cc}
\hline Enzimas & Identidade \% \\
\hline Sc_ASPase1 e Ec_ASPasell & 37,72 \\
Sc_ASPase1 e Ec_ASPasel & 21,57 \\
Ec_ASPasel e Ec_ASPasell & 26,41 \\
$\%$ de identidade calculada pelo programa ClustalW e Jalview.
\end{tabular}

Sc_ASPase1 é uma proteína pouco estudada, sendo que as primeiras caracterizações foram feitas na década de 70 por JONES E MORTIMER (1973), e posteriormente por DUNLOP et al. (1978). Em ambos os estudos, a proteína endógena foi submetida a diversos passos de purificação e, ao final a proteína não estava suficientemente pura, sendo caracterizada com baixa atividade específica e afinidade pelo substrato.

Sc_ASPase 1 só voltou a ser estudada em 2013 por KARAMITROS et al. O grupo estudou a encapsulação da enzima e foi demonstrado que Sc_ASPase1 encapsulada sofre menos ação de proteases e que possui potencial antineoplásico. No entanto, não é relatado nenhum novo estudo de caracterização bioquímica de Sc_ASPase1. 


\section{OBJETIVOS}

\subsection{Objetivo geral}

O objetivo deste trabalho foi avaliar o potencial enzimático de Sc_ASPase1 na depleção L-asparagina e, pela engenharia da proteína e ensaios cinéticos, buscar a melhoria da sua atividade e diminuição dos possíveis efeitos adversos em relação às formulações bacterianas existentes no mercado.

\subsection{Objetivos específicos}

- Produzir Sc_ASPase1 recombinante e caracterizar os parâmetros da cinética enzimática.

- Caracterizar o sítio catalítico de Sc_ASPase1.

- Realizar engenharia de Sc_ASPase1 visando melhorar seus parâmetros cinéticos.

- Determinar os parâmetros cinéticos das isoformas engenheiradas de Sc_ASPase1 e comparar com as enzimas bacterianas.

- Determinar a toxicidade de Sc_ASPase1 em linhagem de LLA. 


\section{MATERIAIS E MÉTODOS}

Plasmídeos: Expressão em E. coli: pET-15b (Merck- Novagen) (Mapa do vetor de expressão no anexo $A$ ).

Linhagens: Bactérias E. coli:

- $\quad \mathrm{DH} 5 \mathrm{a}$ [endA1, hsdR17 (rk $\left.m k^{+}\right)$, supE44, thi 1, recA1, gyrA (Na 1r), relA1, $\triangle$ (lacZYA-argF) U169 (Ф80lacZ $\triangle M 15)]$ (Merck - Novagen).

- $\quad$ BL21(DE3); [F, amp T, hsdSb (rB- mb'), gal, dcm (DE3)] (Merck Novagen).

- AD494: $[\Delta($ araABC-leu)7697 $\Delta l a c X 74 \Delta m a l F 3 \Delta p h o A P v u l l$ phoR $\operatorname{trxB}:: \mathrm{Kan}^{r} \mathrm{~F}^{\prime}\left[\mathrm{lac}{ }^{q}{ }^{q}\right.$ lacZ $\triangle M 15$ proAB $\left.{ }^{+}\right]$(Merck - Novagen).

- Marca de seleção: $15 \mu \mathrm{g} / \mathrm{mL}$ Canamicina (Sigma-Aldrich).

- $\quad$ BL21pLysS(DE3) : [ $F^{-}, o m p T, h s d S_{B}\left(r B^{-}, m B^{-}\right), d c m, g a l, \lambda(D E 3)$, pLysS, $\mathrm{Cm}^{r}$ ](Merck - Novagen).

- Marca de seleção: $34 \mu \mathrm{g} / \mathrm{mL}$ Cloranfenicol (Sigma-Aldrich).

- $\quad$ C43 (DE3): [ $F^{-}$ompT hsdSB (rB- mB') gal dcm (DE3)] (Lucigen).

- Rosetta (DE3): [ $F^{-}$ompt $h s d S B\left(r B^{-} m B^{-}\right)$gal dcm (DE3) pRARE2 $\left.\left(\mathrm{Cam}^{r}\right)\right]$ (Merck - Novagen).

- Marca de seleção: $34 \mu \mathrm{g} / \mathrm{mL}$ de Cloranfenicol (Sigma-Aldrich).

- $\quad$ Arctic (DE3): $\left[F^{-}\right.$ompT $h s d S\left(r B^{-} \mathrm{mB}^{-}\right) \mathrm{dcm}^{+}$Tetr gal $\lambda(D E 3$ endA Hte [cpn10 cpn60 Gent'] (Agilent-Technologies).

- Marca de seleção: $20 \mu \mathrm{g} / \mathrm{mL}$ de Geneticina (Sigma-Aldrich).

- Origami (DE3): [1 $1 \Delta\left(\right.$ ara-leu$^{-} 7697 \Delta$ lacX74 $\Delta p h o A$ Pvull phoR araD139 ahpC galE galK rpsL F'llac lacl q pro] (DE3) gor522::Tn10 trxB (Kan', Str', Tet $\left.t^{\prime}\right)$.

- Marcas de seleção: $50 \mu \mathrm{g} / \mathrm{mL}$ de Estreptomicina (Sigma-Aldrich), $15 \mu \mathrm{g} / \mathrm{mL}$ de Canamicina (Sigma-Aldrich) e $12,5 \mu \mathrm{g} / \mathrm{mL}$ de Tetraciclina (Sigma-Aldrich).

Meio de Cultura: Meio Luria-Bertani (L.B.): $0.5 \% \mathrm{NaCl}, 0.5 \%$ extrato de levedura, $1 \%$ triptona e adição de $2 \%$ de Agar quando o meio for sólido.

Todos os reagentes utilizados foram de grau analítico ou superior obtidos da Sigma-Aldrich, Merck-Millipore, ou indicados quando de origem diferente. 


\subsection{Clonagem de ASP1 por PCR}

O gene ASP1 foi isolado a partir do DNA genômico da linhagem BY4741 de S. cerevisiae - sequencia obtida do banco de dados Saccharomyces Genome Database - por PCR (Polymerase Chain Reaction), utilizando os oligonucleotídeos específicos Fw 5'GGG AAA TTC CAT ATG TTA CCA AGA ATC AAA ATC TTG GG 3' e Rev 5' CGC GGA TCC TCA CCA CCA TAG AC 3' sintetizados pela empresa Exxtend Biotecnologia (São Paulo, Brasil). A reação continha $1 \mathrm{ng} / \mu \mathrm{L}$ de DNA genômico de $S$. cerevisiae, 0,25 mM de DNTP's, 1 $\mathrm{mM} \mathrm{MgCl} 2,1 \mathrm{X}$ de Buffer PCR 10X, 0,02 U/uL de Platinum ${ }^{\circledR}$ Pfx DNA Polymerase (Life Technologies), 0,75 pmol/ $\mu \mathrm{L}$ de cada iniciador. As condições de amplificação consistiram em uma fase inicial de desnaturação do molde a $95^{\circ} \mathrm{C}$ por 5 minutos, seguida de 30 ciclos de desnaturação a $95^{\circ} \mathrm{C}$ por 45 segundos, anelamento dos iniciadores a $55^{\circ} \mathrm{C}$ por 45 segundos e extensão do amplificado a $68^{\circ} \mathrm{C}$ por 1 minuto e 30 segundos e uma fase final de extensão a $68^{\circ} \mathrm{C}$ por 7 minutos, utilizando o termociclador Applied Biosystems-Veriti. A amplificação foi confirmada por eletroforese em gel de agarose $0.8 \%$ em tampão TAE $1 \mathrm{X}$ e $0,5 \mu \mathrm{g} / \mathrm{mL}$ de brometo de etídio. $\mathrm{O}$ tamanho esperado do inserto é de $1.141 \mathrm{bp}$ (www.yeastgenome.org).

\subsection{Reação de Digestão}

O vetor de expressão $\mathrm{pET}-15 \mathrm{~b}$ (Merck- Novagen) e todo o produto de PCR de ASP 1 foram digeridos por 2 horas a $37^{\circ} \mathrm{C}$ em banho-maria com $1 \mathrm{X}$ de

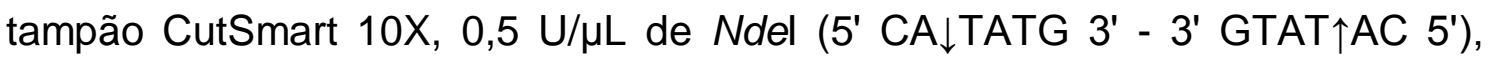

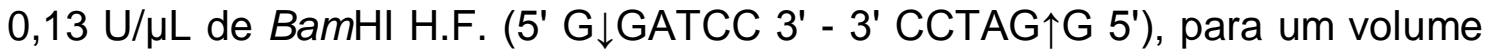
final de $75 \mu \mathrm{L}$ de reação. As enzimas de restrição foram obtidas da empresa NEB - New England BioLabs. 


\subsection{Purificação dos Produtos de digestão}

As amostras de DNA digeridas foram purificadas após separação por eletroforese em gel de agarose $0.8 \%$ em tampão TAE 1 X e $0,5 \mu \mathrm{g} / \mathrm{mL}$ de brometo de etídio usando o kit Gfx Purification (GE Healthcare Life Sciences) de acordo com o protocolo do fabricante.

\subsection{Reação de ligação}

Para a reação de ligação foi utilizado $1,5 \mathrm{ng} / \mu \mathrm{L}$ do vetor $\mathrm{pET} 15 \mathrm{~b}, 0,5$

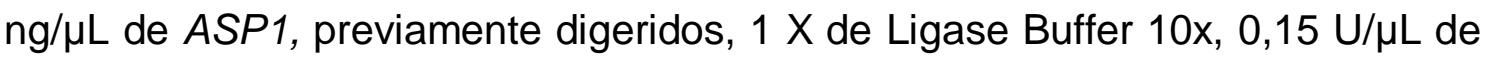
T4 DNA ligase (Promega), totalizando $20 \mu \mathrm{L}$ de reação. As quantidades necessárias para reação foram calculadas com ferramenta BioMath Calculator da

Promega

(http://www.promega.com/a/apps/biomath/index.html?calc=molarity). A reação foi incubada por 3 horas em temperatura ambiente. Toda a reação de ligação foi dialisada em $20 \mathrm{~mL}$ de água milli-Q em membrana de 0,025 $\mu \mathrm{m}$ (MerckMillipore).

\subsection{Transformação em Escherichia coli}

Para obtenção das bactérias eletrocompetentes, as linhagens de E. coli foram crescidas em meio L.B por 16 horas a $37^{\circ} \mathrm{C}$ sob agitação de $180 \mathrm{rpm}$ para obtenção do pré-inóculo. Posteriormente, as células foram diluídas para $\mathrm{OD}_{600 \mathrm{~nm}}=0,2 \mathrm{em} 1 \mathrm{~L}$ de meio L.B. fresco e crescidas até $\mathrm{OD}_{600 \mathrm{~nm}}$ entre $0,6 \mathrm{a}$ 0,8 . Após atingir a OD esperada as células foram mantidas no gelo por 30 minutos e, em seguida centrifugadas por 15 minutos a $4{ }^{\circ} \mathrm{C}, 5.000 \times \mathrm{g} . \mathrm{O}$ sobrenadante foi descartado, as células ressuspendidas em $1 \mathrm{~L}$ de água gelada e centrifugadas como descrito anteriormente; esse procedimento foi 
repetido duas vezes. Foi feita uma terceira lavagem com $20 \mathrm{~mL}$ de glicerol (10\%). Por último, as células foram ressuspendidas em $3 \mathrm{~mL}$ de glicerol (10\%), aliquotadas e armazenadas a $-80^{\circ} \mathrm{C}$.

Após a reação de ligação realizamos a transformação bacteriana na linhagem DH5a eletrocompetente para clonagem e seleção de plasmídeos. Para isso adicionamos toda da reação de ligação dialisada em $50 \mu \mathrm{L}$ de $E$. coli DH5a eletrocompetente e inserimos na cubeta para eletroporação. Eletroporamos a $2,5 \mathrm{kV}$ (no equipamento BioRad®. Gene Pulser II), adicionamos $1 \mathrm{~mL}$ de L.B. fresco na cubeta para desprender as células bacterianas. As células eletroporadas foram incubadas por 1 hora a $37^{\circ} \mathrm{C}$ sob leve agitação. Em seguida todo o conteúdo celular foi plaqueado em meio sólido L.B. com $50 \mu \mathrm{g} / \mathrm{mL}$ de carbenicilina.

As demais linhagens utilizadas para expressão de proteínas (BL21 (DE3), BL21pLysS (DE3), AD494, C43 (DE3), Rosetta (DE3), Origami (DE3) e Arctic (DE3)) foram transformas seguindo o mesmo protocolo.

\subsection{Mini-Preparação de Plasmídeos (miniprep)}

Inóculos de $3 \mathrm{~mL}$ de L.B. $+50 \mu \mathrm{g} / \mathrm{mL}$ de carbenicilina foram feitos com colônias isoladas da linhagem transformante de E. coli (DH5a) (protocolo de transformação descrito abaixo) e incubadas a $37^{\circ} \mathrm{C}, 180 \mathrm{rpm}$ overnight. Os inóculos foram utilizados para fazer a extração plasmidial utilizando o kit QIAprep Spin Miniprep (Qiagen), seguindo o protocolo do fabricante.

\subsection{Construção e clonagem de ASP1 truncada (Asp1p+53)}

A construção $\mathrm{pET} 15 \mathrm{~b}+A S P 1$ foi usada como molde para amplificação da forma truncada com os iniciadores desenhados para obtenção de Asp1p+53. O iniciador Fw foi desenhado para iniciar o alinhamento no $53^{\circ}$ códon (numeração correspondente ao número de aminoácidos retirados da porção $\mathrm{N}$-terminal da 
proteína, isto é, sem os 52 aminoácidos iniciais que não alinham com a região $\mathrm{N}$-terminal das L-ASPases bacterianas). A sequencia deste foi: Fw 5' GGG AAA TTC CAT ATG TTA CCA AGA ATC AAA ATC TTG GG 3'. O iniciador Rev foi o mesmo utilizado para a amplificação da enzima selvagem (descrito no item 3.1). Para a reação de amplificação foi utilizada as mesmas concentrações da reação descrita no item 3.1, utilizando como DNA molde o plasmídeo $\mathrm{pET} 15 \mathrm{~b}+A S P 1$ (obtido da miniprep descrita no item 3.5).

O produto de PCR Asp1p+53 e o vetor de expressão pET15b foram previamente digeridos nos sítios de restrição Ndel e BamHI, purificados (descrito no item 3.2 e 3.3) e ligados com T4 DNA ligase (item 3.4). Em seguida a linhagem de $E$. coli $\mathrm{DH} 5 a$ foi transformada para clonagem e seleção dos plasmídeos, como descrito para a construção $\mathrm{pET15b}+A S P 1$ no item 3.6. $\mathrm{A}$ construção foi confirmada por sequenciamento (descrito em item 3.9). As linhagens BL21 (DE3), AD494, BL21pLysS (DE3), C43 (DE3), Rosetta (DE3), Origami (DE3) e Arctic (DE3) foram transformadas com a construção $p E T 15 b+($ Asp1p+53) seguindo o mesmo protocolo de transformação descrito no item 3.5 .

\subsection{Mutação sítio dirigida}

Para as mutações de caracterização do sítio catalítico e possível melhoria da atividade foi utilizado o kit QuikChange II (Agilent Technologies). Os iniciadores contendo as mutações sítio dirigidas (tabela 3) foram desenhados de acordo com as instruções do manual do fabricante.

Para as reações de mutação foi utilizado como molde $1 \mathrm{ng} / \mu \mathrm{L}$ da

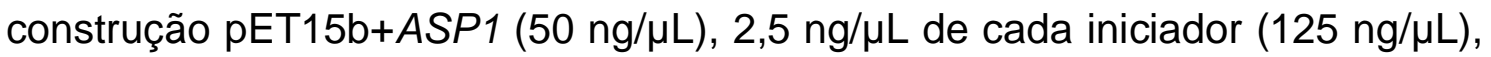
$1 \mathrm{X}$ de tampão $10 \mathrm{X}, 1 \mu \mathrm{L}$ de DNTP mix e 0,05 U/ $\mu \mathrm{L}$ de Pfu turbo polimerase $(2,5 \mathrm{U} / \mu \mathrm{L})$, para $50 \mu \mathrm{L}$ de reação. As condições de amplificação consistiram em uma fase inicial de desnaturação a $95{ }^{\circ} \mathrm{C}$ por 30 segundos, seguida de 16 ciclos de desnaturação a $95{ }^{\circ} \mathrm{C}$ por 30 segundos, anelamento a $55{ }^{\circ} \mathrm{C}$ por 1 minuto e extensão a $68{ }^{\circ} \mathrm{C}$ por 1 minuto por $\mathrm{Kb}$ de plasmídeo (portanto, 7 minutos) e uma fase final de extensão a $68^{\circ} \mathrm{C}$ por 7 minutos. 
Em seguida, a reação foi incubada com $10 \mathrm{U}$ da enzima $D p n /$ a $37^{\circ} \mathrm{C}$ por 1 hora para digestão do DNA parental metilado, e dialisada por 20 minutos em $20 \mathrm{~mL}$ de água milli-Q com membrana de 0,025 $\mu \mathrm{m}$ (Merck- Millipore).

A reação foi transformada em E. coli $(\mathrm{DH} 5 \alpha)$ e 5 clones foram selecionados para a mini-preparação plasmidial (item 3.5). Todas as mutações foram confirmadas por sequenciamento (descrito no item 3.9) antes de transformar a linhagem E. coli (BL21(DE3)) com os mutantes (como descrito no item 3.6).

Tabela 3 - Iniciadores para mutação sítio dirigida

\begin{tabular}{|c|c|c|c|}
\hline Mutação & Códon & & Iniciadores \\
\hline \multirow{2}{*}{ T64A } & \multirow{2}{*}{ ACT/GCG } & Fw & GGGTACCGGTGGTGCGATTGCATCGAAAGC \\
\hline & & Rev & GCTTTCGATGCAATCGCACCACCGGTACCC \\
\hline \multirow{2}{*}{ Y78A } & \multirow{2}{*}{ TAT/GCG } & Fw & AAACTGCCGGCGCGCATGTTGACCTGACC \\
\hline & & Rev & GGTCAGGTCAACATGCGCGCCGGCAGTTT \\
\hline \multirow{2}{*}{ T141A } & \multirow{2}{*}{ ACT/GCC } & Fw & ATTACCCATGGGGCCGATACGCTAT \\
\hline & & Rev & ATAGCGTATCGGCCCCATGGGTAAT \\
\hline \multirow{2}{*}{ K215A } & \multirow{2}{*}{ AAG/GCC } & Fw & TCTGGTTACTACATTACTGCCACGAATGCAAATAGTTTGG \\
\hline & & Rev & CCAAACTATTTGCATTCGTGGCAGTAATGTAGTAACCAGA \\
\hline \multirow{2}{*}{ A331D } & \multirow{2}{*}{ GCC/GTA } & Fw & ATGGTGCCTATTGTAAACGTACCAAAGAAAGG' \\
\hline & & Rev & CCTTTCTTTGGTACGTTACAATAGGCACCAT \\
\hline \multirow{2}{*}{ K335E } & \multirow{2}{*}{ AAG/GAA } & Fw & GCCAACGTACCAGAAAAAGGTTCAAAGGAG \\
\hline & & Rev & СTCCTTTGAACCTTTTTCTGGTACGTTGGC \\
\hline \multirow{2}{*}{$\Delta \mathrm{G} 77$} & \multirow{2}{*}{$\Delta G G C$} & Fw & ССТCTCAAACTGCCTATCATGTTGACCTGACC \\
\hline & & Rev & GGTCAGGTCAACATGATAGGCAGTTTGAGAGG \\
\hline \multirow{2}{*}{ Y243S } & \multirow{2}{*}{ TAT/AGC } & Fw & GAAATTCACTACTATAGCCCTCCTGTGAAACCGC \\
\hline & & Rev & GCGGTTTCACAGGAGGGCTATAGTAGTGAATTTC \\
\hline \multirow{2}{*}{ S301N } & \multirow{2}{*}{ TCA/AAC } & Fw & ACCATGGGTGCTGGTAACTTGCCGGAGGAGG \\
\hline & & Rev & CCTCCTCCGGCAAGTTACCAGCACCCATGGT \\
\hline
\end{tabular}

Em negrito estão os códons que contem a mutação.

\subsection{Reação de Sequenciamento}

Todas as construções e mutações foram confirmadas por sequenciamento seguindo o protocolo do Serviço de Sequenciamento de DNA do Instituto de Química - IQ/USP. Para reação foram utilizados iniciadores para o promotor e para o terminador T7 do vetor pET15b (FW: 5' 
TTAATACGACTCACTATAGGGGAATTGTG 3' e Rev: 5' TGCTAGTTATTGCTCAGCGGTG 3'). A reação consistiu de 100 a $200 \mathrm{ng}$ de DNA (produto de PCR amplificado da construção $p E T 15 b+A S P 1$, selvagem ou mutada, utilizando os iniciadores para T7 descritos acima), 0,64 pmol/ $\mu \mathrm{L}$ de iniciador T7 FW ou Rev , 1 X de sequencing buffer 5 X, $2 \mu \mathrm{L}$ de BigDye v3.1, volume final de $15 \mu \mathrm{L}$. As condições de reação consistiram em uma fase inicial de desnaturação a $96{ }^{\circ} \mathrm{C}$ por 2 minutos, seguida de 35 ciclos de desnaturação a $96{ }^{\circ} \mathrm{C}$ por 45 segundos, anelamento a $53{ }^{\circ} \mathrm{C}$ por 30 segundos e extensão a $60{ }^{\circ} \mathrm{C}$ por 4 minutos e uma faze final de extensão a $60{ }^{\circ} \mathrm{C}$ por 7 minutos. $\mathrm{A}$ precipitação do DNA foi feita adicionando-se aos $15 \mu \mathrm{L}$ da reação de sequenciamento $25 \mu \mathrm{L}$ do coquetel de precipitação (composto por $92,6 \%$ de etanol gelado, $111 \mathrm{mM} \mathrm{NaOAc} \mathrm{pH} 5,2$ e $37 \mu \mathrm{g} / \mathrm{mL}$ de glicogênio), vortexado e mantido no gelo por 15 minutos. Em seguida, a reação foi centrifugada a 4.000 x $g$ por 20 minutos a temperatura ambiente, a placa foi invertida para descartar o excesso de solução por meio de um pulso de centrifugação a $1.000 \times \mathrm{g}$. Adicionou-se a reação $50 \mu \mathrm{L}$ de etanol $70 \%$ gelado, repetiu-se a centrifugação por 10 minutos e a inversão de placa. A reação foi colocada no termociclador por 1 minuto a $95{ }^{\circ} \mathrm{C}$ para secagem final e enviadas ao Serviço de sequenciamento de DNA (IQ-USP).

\subsection{Expressão e Purificação de proteína por cromatografia de afinidade a metais (níquel) - IMAC}

\subsubsection{Sc_ASPase1 selvagem e Isoformas mutantes}

Foram crescidos pré-inóculos de $50 \mathrm{~mL}$ de colônias únicas em L.B. com $50 \mu \mathrm{g} / \mathrm{mL}$ de carbenicilina por 16 horas a $37^{\circ} \mathrm{C}$ sob agitação de $180 \mathrm{rpm}$. As células foram diluídas para $\mathrm{OD}_{600 \mathrm{~nm}}=0,2 \mathrm{em} 1 \mathrm{~L}$ de meio L.B. fresco com 50 $\mu \mathrm{g} / \mathrm{mL}$ de carbenicilina e crescidas até $\mathrm{OD}_{600 \mathrm{~nm}}$ entre 0,6 a 1,0; adicionou-se 1 $\mathrm{mM}$ do indutor isopropil- $\beta$-D-1-tiogalactopiranosido (IPTG), por 3 horas $37^{\circ} \mathrm{C}$ 
sob agitação de $180 \mathrm{rpm}$. As células foram centrifugadas a $4.000 \times \mathrm{g}$ por 20 minutos a $4{ }^{\circ} \mathrm{C}$.

O pellet foi ressuspendido com start buffer (20 mM tampão Tris- $\mathrm{HCl}$ pH 7,4, $300 \mathrm{mM}$ de $\mathrm{NaCl}, 50 \mathrm{mM}$ de imidazol), adicionado de $1 \mathrm{mM}$ de fluoreto de fenilmetilsulfonil (PMSF) e sonicado 24 vezes por 5 segundos com $30 \%$ de amplitude e repouso por 15 segundos no gelo entre as pulsos. O lisado das células foi tratado com $1 \%$ de sulfato de estreptomicina no gelo por 20 minutos sob leve agitação magnética, a suspensão foi centrifugada a $16.000 \mathrm{X} g$ por 30 minutos. $O$ extrato proteico foi filtrado em membrana de 0,45 $\mu \mathrm{m}$ (MerckMillipore) e aplicado na coluna de afinidade a níquel Hi-Trap (GE Healthcare) para purificação.

A purificação utilizando a coluna Hi-Trap HP de $5 \mathrm{~mL}$ (GE Healthcare) foi realizada seguindo o protocolo, de acordo com o manual do fabricante. Brevemente, a coluna foi lavada com $50 \mathrm{~mL}$ de água Milli-Q para lavar a solução de estocagem; adicionou-se $2.5 \mathrm{~mL}$ de sulfato de níquel $0,1 \mathrm{M}$ para carregar a coluna e essa foi lavada novamente com $50 \mathrm{~mL}$ de água Milli-Q para retirar o excesso de níquel não incorporado da coluna. A coluna foi equilibrada com $50 \mathrm{~mL}$ de start buffer (20 mM tampão Tris- $\mathrm{HCl}$ pH 7,4, $300 \mathrm{mM}$ de $\mathrm{NaCl}$, $20 \mathrm{mM}$ de imidazol) e aplicou-se a amostra proteica. Em seguida a coluna foi lavada com $50 \mathrm{~mL}$ de wash buffer1 (20 mM tampão Tris- $\mathrm{HCl} \mathrm{pH} \mathrm{7,4,300} \mathrm{mM}$ de $\mathrm{NaCl}, 50 \mathrm{mM}$ de imidazol) seguido de $50 \mathrm{~mL}$ de wash buffer2 $(20 \mathrm{mM}$ tampão Tris- $\mathrm{HCl} \mathrm{pH} \mathrm{7,4,} 300 \mathrm{mM}$ de $\mathrm{NaCl}, 150 \mathrm{mM}$ de imidazol) para retirar o excesso de proteínas ligadas de forma inespecífica na coluna. Por fim, a eluição da proteína alvo foi feita com solução elute buffer (20 mM tampão Tris$\mathrm{HCl} \mathrm{pH} \mathrm{7,4,} 300 \mathrm{mM}$ de $\mathrm{NaCl}, 500 \mathrm{mM}$ de imidazol). A presença de proteína nas frações coletadas foi verificada por reagente de Bradford (BioAgency).

\subsubsection{Sc_ASPase1 truncada (Asp1p+53)}

A proteína Asp1p+53 foi expressa na fração insolúvel nas condições de crescimento e indução citadas no item 3.10.1; assim, essas condições foram modificadas. Para a linhagem BL21 (DE3) foram crescidos dois pré-inóculos de 
$10 \mathrm{~mL}$ de colônias únicas em L.B. com $50 \mu \mathrm{g} / \mathrm{mL}$ de carbenicilina; um préinóculo foi incubado a $37{ }^{\circ} \mathrm{C}$ e o outro a $20^{\circ} \mathrm{C}$, ambos por 16 horas sob agitação em shaker de $180 \mathrm{rpm}$. As células de cada pré-inóculo foram diluídas para $\mathrm{OD}_{600 \mathrm{~nm}}=0,2 \mathrm{em} 100 \mathrm{~mL}$ de meio L.B. fresco com $50 \mu \mathrm{g} / \mathrm{mL}$ de carbenicilina e crescidas até ${ }^{O} D_{600 n m}$ entre 0,6 a 1,0 nas respectivas temperaturas. Após atingir a OD esperada adicionou-se 0,5 mM de IPTG e incubou-se por 16 horas, a $20{ }^{\circ} \mathrm{C}$ sob agitação de $180 \mathrm{rpm}$. As células foram centrifugadas $4.000 \times g$ por 20 minutos a $4^{\circ} \mathrm{C}$.

As linhagens AD494, BL21pLysS (DE3), C43 (DE3), Rosetta (DE3), Origami (DE3) e Arctic (DE3) foram expressas em duas condições diferentes (tabela 4). Pré-inóculos de $10 \mathrm{~mL}$ de colônias únicas em L.B. com $50 \mu \mathrm{g} / \mathrm{mL}$ de carbenicilina e com o antibiótico marcador de cada linhagem foram incubados a $37^{\circ} \mathrm{C}$ por 16 horas sob agitação em shaker de $180 \mathrm{rpm}$. As células de cada pré-inóculo foram diluídas para $\mathrm{OD}_{600 \mathrm{~nm}}=0,2$ em $20 \mathrm{~mL}$ de meio L.B. fresco com $50 \mu \mathrm{g} / \mathrm{mL}$ de carbenicilina e com o antibiótico marcador de cada linhagem e crescidas até $\mathrm{OD}_{600 \mathrm{~nm}}$ entre 0,4 a 0,6 a $250 \mathrm{rpm}$. , a $30^{\circ} \mathrm{C}$ para linhagem Arctic (DE3) e $37{ }^{\circ} \mathrm{C}$ para as demais linhagens. Após a indução as células foram centrifugadas a $4.000 \times g$ por 20 minutos a $4{ }^{\circ} \mathrm{C}$.

Tabela 4 - Condições de indução de Asp1p+53.

\begin{tabular}{|c|c|c|}
\hline Linhagem & 0,1 mM IPTG & $1 \mathrm{mM}$ IPTG \\
\hline $\begin{array}{l}\text { AD494 } \\
\text { BL21pLysS (DE3) } \\
\text { C43 (DE3) } \\
\text { Rosetta (DE3) } \\
\text { Origami (DE3) } \\
\text { Arctic (DE3) }\end{array}$ & $\begin{array}{l}20^{\circ} \mathrm{C} \text { - overnight } \\
20^{\circ} \mathrm{C} \text { - overnight } \\
20^{\circ} \mathrm{C} \text { - overnight } \\
20^{\circ} \mathrm{C} \text { - overnight } \\
20^{\circ} \mathrm{C} \text { - overnight } \\
12^{\circ} \mathrm{C} \text { - overnight }\end{array}$ & $\begin{array}{l}37^{\circ} \mathrm{C}-3 \text { horas } \\
37^{\circ} \mathrm{C}-3 \text { horas } \\
37^{\circ} \mathrm{C}-3 \text { horas } \\
37^{\circ} \mathrm{C}-3 \text { horas } \\
37^{\circ} \mathrm{C}-3 \text { horas } \\
12^{\circ} \mathrm{C}-\text { overnight }\end{array}$ \\
\hline
\end{tabular}

O pellet foi ressuspendido e lisado, invertendo o tubo gentilmente, em 10 $\mathrm{mL}$ de BugBuster Master MIX (Novagen®) para cada $1 \mathrm{~g}$ de célula. O lisado celular foi centrifugado a $16.000 \times \mathrm{g}$ por 20 minutos e o sobrenadante coletado (fração solúvel). O pellet do lisado (fração insolúvel) foi ressuspendido em 100 $\mu \mathrm{L}$ de água e, para $10 \mu \mathrm{L}$ foi adicionado $5 \mu \mathrm{L}$ de Cracking Buffer (60 mM Tris$\mathrm{HCl} \mathrm{pH}$ 6,8, $10 \%$ glicerol, 1\% SDS, 0,01\% bromofenol, $1 \% \beta$ mercaptoethanol). Em seguida as amostras das frações solúvel e insolúvel foram incubadas a $95^{\circ} \mathrm{C}$ por 5 minutos e submetidas à SDS-PAGE. 
As amostras que apresentaram expressão na fração solúvel foram aplicadas na coluna de afinidade a níquel Hi-Trap de $1 \mathrm{~mL}$ (GE Healthcare) para purificação, seguindo o protocolo do fabricante, como descrito no item 3.10.1. O volume das soluções foi de $10 \mathrm{~mL}$ e a coluna foi lavada somente com a wash buffer 1. A purificação da proteína for confirmada por SDS-PAGE.

\subsection{Gel SDS-PAGE}

A confirmação de purificação e integridade da proteína de interesse foi feita por eletroforese com gel SDS-PAGE 14\% (LAEMMLI, 1970). Gel de separação: $470 \mathrm{mM}$ de tampão Tris- $\mathrm{HCl} \mathrm{pH}$ 8,8; $14 \%$ de acrilamida/bisacrilamida; $0,1 \%$ de PSA; $10 \mu \mathrm{L}$ de TEMED. Gel empacotador: $120 \mathrm{mM}$ tampão Tris-HCl pH 6,8; 4,5 \% de acrilamida/bis-acrilamida; 2,3 mL de $\mathrm{H}_{2} \mathrm{O} ; 0,1$ $\%$ de PSA; $10 \mu \mathrm{L}$ de TEMED.

As amostras proteicas foram fervidas a $95{ }^{\circ} \mathrm{C}$ por 5 minutos na presença de tampão de amostra $1 \mathrm{X}$ (60 mM de Tris- $\mathrm{HCl}$ pH 6,8; $25 \%$ de glicerol; $2 \%$ de SDS; $0,5 \mathrm{~mL}$ de $\beta$-mercaptoethanol; $0,1 \%$ de azul de bromofenol) e $0,5 \mu \mathrm{L}$ de DTT 1 M. Para amostras insolúveis, o pellet foi dissolvido em $100 \mu \mathrm{L}$ de água, uma alíquota de $10 \mu \mathrm{L}$ foi misturada a $5 \mu \mathrm{L}$ de cracking buffer e fervida a $95^{\circ} \mathrm{C}$ por 5 minutos. Em seguida, as amostras e o padrão de massa molecular BenchMark (Invitrogen) foram aplicados no gel e a corrida foi realizada a $160 \mathrm{~V}$ com tampão Tris-Glicina 1X (25 mM de Tris; $192 \mathrm{mM}$ de glicina; 3,5 mM de SDS). O gel foi corado com Coomassie Brilliant Blue R-250 sob leve agitação por 20 minutos e descorado com solução descorante (10\% de metanol; $10 \%$ de ácido acético glacial; $80 \%$ de $\mathrm{H}_{2} \mathrm{O}$ milli-Q) sob leve agitação por 16 horas.

\subsection{Polimento da purificação}

A proteína foi dessalinizada por cromatografia de exclusão molecular com a PD-10 Desalting Columns (GE Healthcare Life Sciences) seguindo o 
protocolo do fabricante. De forma breve, a coluna foi lavada com $50 \mathrm{~mL}$ de água milli-Q para retirada da solução estoque, depois foi equilibrada com 25 $\mathrm{mL}$ de tampão $20 \mathrm{mM}$ Tris- $\mathrm{HCl} \mathrm{pH} 8,8$. Em seguida $2,5 \mathrm{~mL}$ da solução de proteína foram passados pela coluna e eluídas em $3,5 \mathrm{~mL}$ de tampão $20 \mathrm{mM}$ Tris- $\mathrm{HCl} \mathrm{pH} 8,8$ e armazenada a $4{ }^{\circ} \mathrm{C}$ por até 10 dias.

A proteína foi concentrada por ultrafiltração em membrana usando o AmiconUltra $15 \mathrm{~mL}$ com corte de $10 \mathrm{kDa}$ NMWL com membrana de celulose regenerada (Merck-Millipore). A quantificação de proteína foi obtida pela leitura a $280_{\mathrm{nm}}$ em espectrofotômetro, e aplicando a lei de Lambert-beer, utilizando o coeficiente de extinção molar para proteína oxidada, $\varepsilon=25955 \mathrm{M}^{-1} \mathrm{~cm}^{-1}$, obtido

com ferramenta de bioinformática ProtParam (http://web.expasy.org/protparam/).

\subsection{Determinação da Atividade Específica e Parâmetros Cinéticos}

Após a purificação a atividade específica para L-asparagina foi determinada pela quantificação de amônio $\left(\mathrm{NH}_{4}{ }^{+}\right)$produzido na hidrólise de Lasparagina catalisada pela Sc_ASPase1 utilizando o reagente de Nessler e pelo ensaio acoplado ao consumo de NADH.

O reagente de Nessler é uma solução de tetraiodomercurato (II) de potássio que detecta nitrogênio amoniacal formando um precipitado amareloacastanhado, representado na reação 1 . Neste método a determinação em $\mu \mathrm{mol}$ de $\mathrm{NH}_{4}{ }^{+}$produzido pela enzima foi realizada com curva de calibração de sulfato de amônio feita nas mesmas condições do ensaio.

$$
\mathrm{NH}_{3}+2\left[\mathrm{Hgl}_{4}\right]^{--}+3 \mathrm{OH}^{-} \rightarrow \mathrm{Hg}_{2} \mathrm{O}\left(\mathrm{NH}_{2}\right) \mathrm{I}^{-}+7 \mathrm{I}^{-}+2 \mathrm{H}_{2} \mathrm{O} \text { reação } 1
$$

No ensaio acoplado ao consumo de NADH o amônio liberado na hidrólise de L-asparagina é usado para síntese de L-glutamato via L-glutamato desidrogenase $(G D H)$ e NADH como um reagente redox, representado na reação 2. Durante a reação uma molécula de $\mathrm{NH}_{4}{ }^{+}$consumido equivale estequiometricamente a uma molécula de NADH que é oxidada a NAD ${ }^{+}$. 


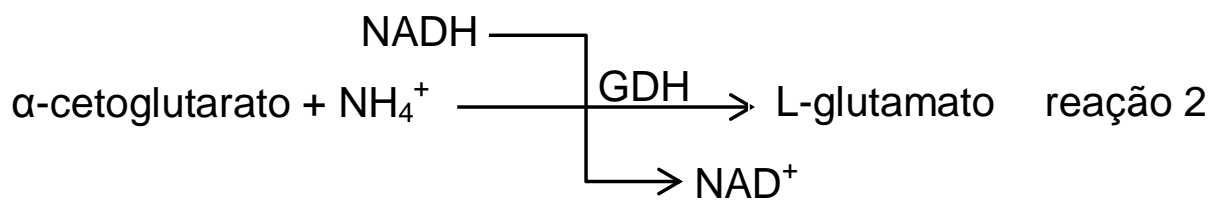

As L-ASPases também podem apresentar atividade de L-glutaminase. A determinação da atividade L-glutaminásica de Sc_ASPase1 não foi possível pelo ensaio com reagente de Nessler, pois a hidrólise espontânea de Lglutamina é alta e o amônio liberado reage rapidamente com reagente, impedindo a quantificação correta por este método. Desta forma, a determinação da atividade L-glutaminásica foi feita pelo ensaio acoplado ao consumo de NADH, utilizando o amônio liberado na hidrólise de L-glutamina.

Em ambos os ensaios, a atividade específica de Sc_ASPase1 foi feita variando a concentração da enzima e fixando a concentração de L-asparagina ou L-glutamina. O branco da reação foi feito com a ausência de L-asparagina e o controle negativo na ausência da enzima para o método colorimétrico. Para o ensaio acoplado o branco foi feito com a ausência de NADH e o controle negativo na ausência de substrato. Como controle, realizamos o ensaio de atividade para L-asparagina e L-glutamina com enzima a Ec_ASPasell comercial (Prospec-Tany) nas mesmas condições utilizadas para Sc_ASPase1.

\subsubsection{Determinação da Atividade Específica}

O ensaio de atividade específica foi realizado em microplacas, utilizando 50 $\mathrm{mM}$ Tris- $\mathrm{HCl}$ pH 8,8, $20 \mathrm{mM}$ de L-asparagina e quantidade de enzima variando de 0 a $0,00126 \mathrm{mg}$ de proteína. A reação $\left(370 \mu \mathrm{L}\right.$ volume final) foi incubada a $37^{\circ} \mathrm{C}$ por 20 minutos e parada com $17 \mu \mathrm{L}$ de 1,5 M ácido tricloroacético - TCA (IMADA et al. 1973; PRADHAN et al. 2013). A reação foi diluída $10 \mathrm{X}$ em água, adicionado $37 \mu \mathrm{L}$ de Reagente de Nessler (Merck), volume final de $370 \mu \mathrm{L}$, e incubada por 10 minutos a temperatura ambiente. A leitura foi realizada a $440_{\mathrm{nm}}$ em espectrofotômetro SpectraMax Microplate Reader (Molecular Devices). Para as isoformas mutantes T64A, Y78A, T141A E K215A foi utilizado entre 0,03 mg e 0,27 mg de proteína, 
$20 \mathrm{mM}$ de L-asparagina e incubadas por 1 hora a $37{ }^{\circ} \mathrm{C}$; para os mutante A331D, K335E, $\Delta$ G77, Y243S e S301N foi utilizado entre $0,00009 \mathrm{mg}$ e 0,09 mg de proteína com $20 \mathrm{mM}$ de L-asparagina por 20 minutos a $37^{\circ} \mathrm{C}$. Para determinação da velocidade inicial a reação foi interrompida a cada 2 minutos por 30 minutos.

A curva padrão foi feita com sulfato de amônio (Sigma-Aldrich) variando a concentração entre 0 e $20 \mu \mathrm{mol} / \mathrm{mL}$ (ORSONNEAU et al., 2004) nas mesmas condições dos ensaios. O tempo total de reação foi determinado por regressão linear de $\mu \mathrm{mol}$ de amônio produzido em função da quantidade de proteína em diferentes tempos, garantindo que a enzima esteja na velocidade inicial.

A determinação da atividade L-glutaminásica foi feita por ensaio acoplado pela hidrólise de L-glutamina e oxidação de $\mathrm{NADH}$, na presença de

glutamato desidrogenase (GDH), o protocolo foi adaptado de BALCÃO et al.

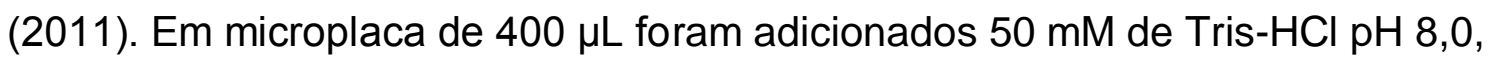
$20 \mathrm{mM}$ L-glutamina, 0,13 mM NADH, 0,5 U GDH (diluída em $50 \mathrm{mM}$ fosfato de sódio $\mathrm{pH} 7,4 ; 50 \%$ glicerol), $1 \mathrm{mM}$ de a-cetoglutarato e de $18 \mu \mathrm{g}$ a $72 \mu \mathrm{g}$ enzima. A absorbância foi medida a $\lambda=340_{\mathrm{nm}}$ a $37^{\circ} \mathrm{C}$ usando o coeficiente de extinção determinado experimentalmente por BALCÃO et al. (2011) de 0,85 $\mu \mathrm{mol}^{-1} . \mathrm{cm}^{-1}$.

\subsubsection{Determinação dos parâmetros cinéticos}

Para determinação dos parâmetros cinéticos foi utilizado o mesmo ensaio acoplado descrito acima, em duas condições. Um ensaio somente com L-asparagina nas concentrações de $0,07 \mathrm{mM}, 0,1 \mathrm{mM}, 0,3 \mathrm{mM}, 0,5 \mathrm{mM}, 0,7$ $\mathrm{mM}, 1,5 \mathrm{mM}, 2,0 \mathrm{mM}$ e 2,5 mM, e a quantidade de Sc_ASPase1 foi de 0,18 $\mu \mathrm{g}$ $(10 \mathrm{nM})$. Um segundo ensaio foi realizado nas mesmas concentrações de Lasparagina e adição de L-glutamina na proporção de 1: 16 para cada concentração de L-asparagina, a concentração de L-glutamina utilizadas foram de 1,12 mM, 1,6 mM, 4,8 mM, 8,0 mM, 11,2 mM, $24 \mathrm{Mm}, 32 \mathrm{mM}$ e $40 \mathrm{mM}$. Para as isoformas mutantes A331D, K335E e S301N o ensaio foi feito somente 
com L-asparagina nas mesmas concentrações e 0, $36 \mu \mathrm{g}(20 \mathrm{nM})$ de proteína. A determinação da cinética foi feita a regressão não linear da velocidade inicial em função da concentração de substrato.

Como controle os ensaios de atividade específica e cinética foram realizados ensaios nas mesmas condições descritas acima para enzima Ec_ASPasell comercial (Prospec-Tany - Israel). Para atividade de Lasparaginase foi utilizado entre 0,051 e 0,51 $\mu \mathrm{g}$ de enzima e $20 \mathrm{mM}$ de Lasparagina. Para atividade L-glutaminásica foi utilizado entre 0,068 e 0,476 $\mu \mathrm{g}$ de proteína e $20 \mathrm{mM}$ de L-glutamina. No ensaio de cinética foi utilizado 0,000136 mg (10 nM) de enzima e entre 0,01 e 2,0 mM de L-asparagina.

\subsubsection{Análise dos dados}

As análises dos dados e as análises estatísticas (teste $\mathrm{F}$ para cinética enzimática e teste $T$ para os mutantes T64A, Y78A, T141A E K215A) foram feitas utilizando o programa GraphPad Prism 5.0. Todos os ensaios foram feitos em triplicatas e os resultados estão representados pela média \pm desvio padrão. A atividade específica é dada em $\mathrm{U} / \mathrm{mg}$ de proteína, em que uma unidade $(U)$ significa a quantidade de enzima necessária para produzir $1 \mu \mathrm{mol}$ de amônia por minuto a $37^{\circ} \mathrm{C}$.

\subsection{Ensaio de citotoxicidade}

As linhagens celulares de leucemia MOLT-4 e Reh foram obtidas do Banco de Células do Rio de Janeiro (RJ/Brasil) e, a linhagem HUVEC foi concedida pela Profa. Dra. Sandra H. P. Farsky do Departamento de Análises Clínicas e Toxicológicas da Faculdade de Ciências Farmacêuticas - FCF/USP.

As células foram mantidas em RPMI 1640 (Vitrocell) com 10\% soro fetal bovino (Vitrocell) (v/v) e incubadas a $37{ }^{\circ} \mathrm{C}$ com $5 \% \mathrm{CO}_{2}$, seguindo as 
instruções do ATCC (http://www.atcc.org/). O repique das células foi feito após atingirem uma alta densidade celular, com de confluência maior que $90 \%$. As linhagem celulares MOLT-4 e Reh foram centrifugadas a $600 \mathrm{Xg}$ a $4{ }^{\circ} \mathrm{C}$ por 10 minutos e ressuspendidas em meio fresco. Para linhagem HUVEC, as células foram tripsinizadas com $0,05 \mathrm{~mL} / \mathrm{cm}^{2}$ de solução de Tripsina/EDTA (Vitrocell), ressuspendidas em meio fresco e posteriormente centrifugadas a $600 \mathrm{Xg}$ a 4 ${ }^{\circ} \mathrm{C}$ por 10 minutos e ressuspendidas em meio fresco.

Em microplacas de 24 poços foram incubadas $1,0 \times 10^{4}$ células com 10 $\mathrm{U} / \mathrm{mL}$ de Sc_ASPase1 ou de Ec_ASPasell (Prospec-Tany), e o mesmo volume

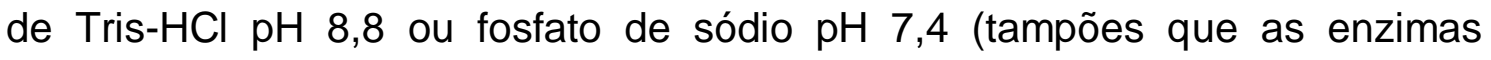
estavam diluídas) por 24,48 e 72 horas a $37{ }^{\circ} \mathrm{C}$ com $5 \% \mathrm{CO}_{2}$. As células foram centrifugadas, ou tripsinizadas anteriormente para a linhagem HUVEC, e coradas com azul de Trypan (Sigma-Aldrich/USA) para selecionar as células mortas. As células foram contadas em câmara de Neubauer para determinação da viabilidade celular. $O$ ensaio foi feito em triplicata experimental e a análise dos dados com o programa GraphPad Prism 5.0. 


\section{RESULTADOS}

\subsection{Obtenção e determinação dos parâmetros cinéticos de}

\section{Sc_ASPase1}

O plasmídeo pET15b+ASP1 foi expresso em E. coli (BL21(DE3)) e a proteína Sc_ASPase1 purificada por cromatografia de afinidade a metal. $\mathrm{O}$ vetor de expressão pET15b insere uma cauda de seis histidinas (His-Tag) na região $\mathrm{N}$-terminal, o que possibilita a purificação das proteínas recombinantes expressas nesse vetor por IMAC. A purificação da proteína foi confirmada por gel SDS-PAGE redutor. Sc_ASPase1 possui aproximadamente $45 \mathrm{kDa}$ com adição da cauda de histidina (figura 6). A massa molecular da proteína foi calculada com a ferramenta de bioinformática ProtParam (http://web.expasy.org/protparam/).

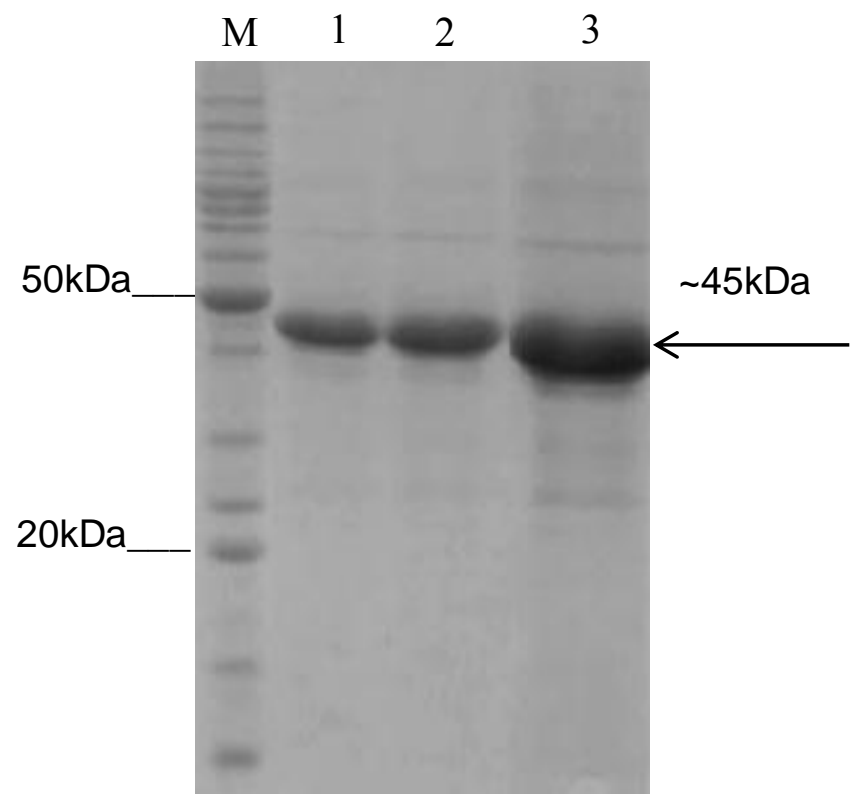

Figura 6 - SDS-PAGE em gel 14\% após a purificação de Sc_ASPase1. O gel redutor foi corado com Coomassie Brilliant Blue R-250; M é o padrão de massa molecular BenchMarck (Invitrogen). As amostras 1, 2 e 3 são diferentes frações da eluição com 500 mM de imidazol da purificação de Sc_ASPase1 em coluna de níquel.

Com a proteína pura, nós determinamos a atividade específica para Lasparagina pela quantificação de amônio $\left(\mathrm{NH}_{4}{ }^{+}\right)$produzido na hidrólise de Lasparagina catalisada pela Sc_ASPase1 utilizando o reagente de Nessler e 
pelo ensaio acoplado ao consumo de NADH. Para determinação da atividade L-glutaminásica foi utilizado ensaio acoplado ao consumo de $\mathrm{NADH}$, utilizando o amônio liberado na hidrólise de L-glutamina.

Em ambos os ensaios, a atividade específica de Sc_ASPase1 foi feita variando a concentração da enzima e fixando a concentração de L-asparagina ou L-glutamina em $20 \mathrm{mM}$. O branco da reação foi feito com a ausência de Lasparagina e o controle negativo na ausência da enzima para o método colorimétrico. Para o ensaio acoplado o branco foi feito com a ausência de $\mathrm{NADH}$ e o controle negativo na ausência de substrato. A velocidade inicial da enzima foi determinada por regressão linear. Como controle, realizamos o ensaio de atividade para L-asparagina e L-glutamina com enzima a Ec_ASPasell comercial (Prospec-Tany) nas mesmas condições utilizadas para Sc_ASPase1.

Sc_ASPase 1 apresentou uma atividade específica para L-asparagina de $195 \pm 6 \mathrm{U} / \mathrm{mg}$ pela metodologia com reagente de Nessler, enquanto que pelo consumo de NADH a atividade foi de $95 \pm 6 \mathrm{U} / \mathrm{mg}$. Para L-glutamina a atividade específica foi de 0,4 \pm 0,02 $\mathrm{U} / \mathrm{mg}$ (figura 7). Devido à utilização de metodologias distintas para determinação da atividade específica frente a ambos os substratos, a atividade de L-glutaminase foi comparada com a atividade de L-asparaginase obtida pelo ensaio acoplado ao consumo de NADH. Por tanto, a atividade de L-glutaminase de Sc_ASPase1 é de 0,38\% da sua atividade L-asparaginásica.

A diferença de aproximadamente duas vezes na atividade específica para L-asparagina também foi observada com Ec_ASPasell comercial (Prospec-Tany). Segundo as especificações do fabricante, a atividade específica para L-asparagina é de $225 \mathrm{U} / \mathrm{mg}$ (http://www.prospecbio.com/LAsparaginase_8_46/). Pelo método colorimétrico, a enzima de E. coli apresentou uma atividade de $233 \pm 7 \mathrm{U} / \mathrm{mg}$ para L-asparagina e, de $121 \pm 3$ $\mathrm{U} / \mathrm{mg}$ pelo consumo de NADH. A atividade L-glutaminásica obtida para Ec_ASPasell comercial pelo ensaio acoplado foi de $12 \pm 1 \mathrm{U} / \mathrm{mg}$, o que representa $10 \%$ da atividade de L-asparaginase da enzima utilizando a mesma metodologia como referência. Os gráficos estão representados no anexo B.

A diferença dos valore obtidos entre as duas metodologia é proporcional para as duas enzimas e esperada devido à diferença de sensibilidade dos 
ensaios. Os valores de atividade L-glutaminásica encontrados para Ec_ASPasell dentro dos valores de $2 \%$ a $10 \%$ da atividade de L-asparginase descritos na literatura (NARTA et al., 2007) e, o valor da atividade de Lasparaginase obtida por meio do reagente de Nessler próximo as especificações do fabricante validam os nossos ensaios.

Portanto, Sc_ASPase1 apresentou uma atividade específica para Lasparagina muito próxima ao da enzima comercial e para L-glutamina uma atividade aproximadamente vinte e cinco vezes menor.

A

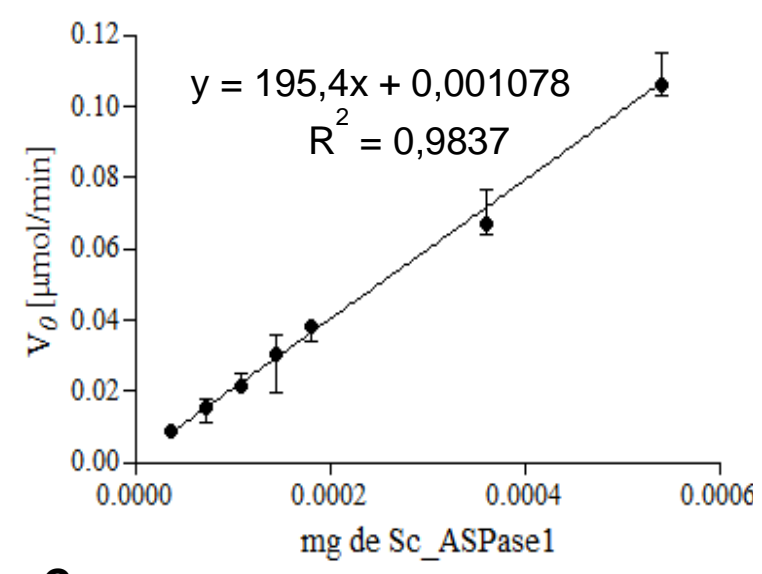

C

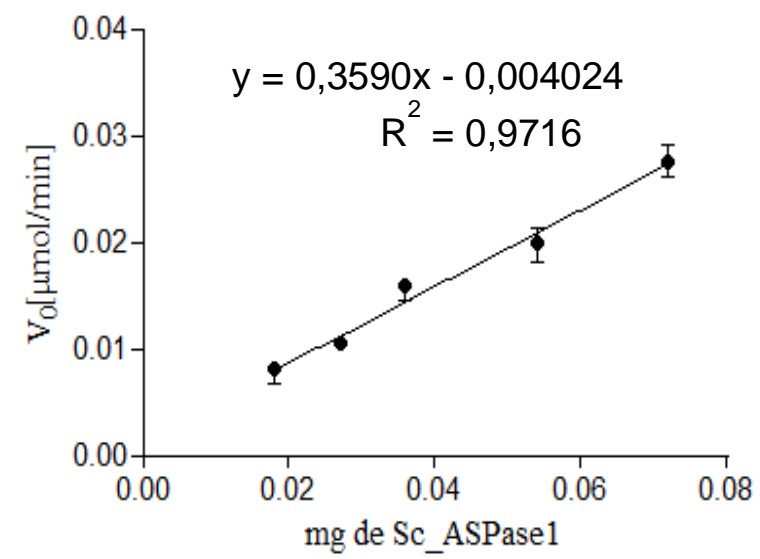

B

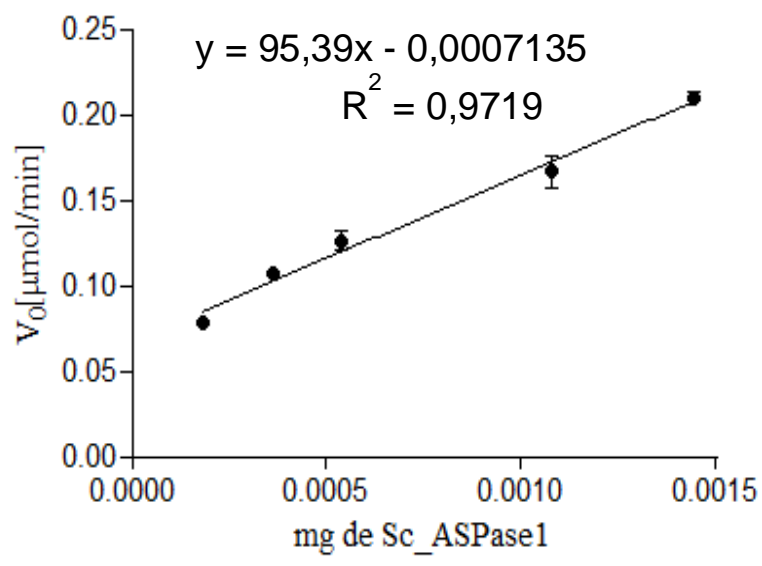

Figura 7 - Atividade específica de Sc_ASPase1. Gráfico da reação de velocidade inicial em função da quantidade em $\mathrm{mg}$ de proteína purificada. A: Gráfico da atividade específica para Lasparagina determinada por reagente de Nessler. B: Gráfico da atividade específica na presença de L-asparagina determinada pelo ensaio acoplado ao consumo de NADH. C: Gráfico da atividade específica na presença de L-glutamina determinada pelo ensaio acoplado ao consumo de $\mathrm{NADH}$. Os pontos representam a média \pm desvio padrão $(n=3)$. O coeficiente angular da equação de reta representa a atividade em $\mathrm{U} / \mathrm{mg}$ de proteína. O gráfico e a determinação das atividades foram obtidas com programa GraphPad Prism v.5.0.

Para determinação dos parâmetros cinéticos também foi utilizado o ensaio acoplado ao consumo de NADH, pois a determinação da cinética por 
meio do reagente de Nessler não foi reprodutível. Neste ensaio, a concentração de L-asparagina variou de $0,07 \mathrm{mM}$ a $2,5 \mathrm{mM}$ e a quantidade de Sc_ASPase1 foi de $0,18 \mu \mathrm{g}(0,01 \mu \mathrm{M})$. As diferentes concentrações de substrato e as respectivas velocidades de Sc_ASPase1 $(\mu \mathrm{mol} / \mathrm{min})$ foram analisadas utilizando regressão não linear nos modelos Michaelis-Menten e Alostérico sigmoidal com o programa GraphPad Prism v 5.0.

Foi feita uma análise estatística entre os dois modelos utilizando o teste F sob a hipótese nula da enzima ser michaeliana, a fim de determinar qual o melhor modelo cinético para Sc_ASPase1. A análise determinou o melhor modelo como o alostérico sigmoidal, com $R^{2}=0,9726$ e $p<0,0001$ (figura 8A). Como controle do ensaio realizamos a cinética com Ec_ASPasell comercial (Prospec-Tany). A enzima apresentou um comportamento michaeliano com o $\mathrm{R}^{2}=0,9797$ e um $K_{\mathrm{m}}$ na faixa de $\mu \mathrm{M}$, como descrito na literatura. $O$ gráfico está representado no anexo $B$ e os parâmetros cinéticos na tabela 4 .

O gráfico de velocidade versus concentração de substrato com uma curva de saturação sigmoide, ao invés de uma curva hiperbólica como em Michaelis-Menten, é característico de enzimas alostéricas (NELSON e COX, 2011). Uma cinética enzimática com perfil sigmoide em geral reflete interações cooperativas entre as subunidades (cooperatividade alostérica), onde a interação com o ligante promove mudanças na estrutura de uma subunidade que são convertidas em mudanças estruturais nas subunidades adjacentes, resultando na alteração conformacional da proteína (KOSHLAND e HAMADANI, 2002).

A cooperatividade alostérica é medida pelo coeficiente de Hill $\left(n_{H}\right)$ que fornece uma medida do desvio da cinética de Michaelis-Menten. Se $\mathrm{n}_{H}$ é igual a 1 a interação com o ligante não é cooperativa; se $\mathrm{n}_{H}$ é menor do que 1 , indica uma cooperatividade negativa; se $\mathrm{n}_{H}$ é maior do que 1 a cooperatividade é positiva (RICARD e CORNISH-BOWDEN, 1987). Em Sc_ASPase1 a cooperatividade apresentada foi positiva, demonstrada pelo coeficiente de Hill $n_{H}=2,2$ (figura 8B). Os valores dos parâmetros cinéticos estão relacionados na tabela 4.

ANISHKIN ET AL. (2015) demonstram que a Ec_ASPasell possui um perfil alostérico com cooperatividade positiva $\left(n_{H}=1,5\right)$ regulada pela Lglutamina. Os autores propõem que em condições de concentrações 
submicromolar de L-asparagina, como ocorre no sangue durante o tratamento da LLA, a L-glutamina que é mais abundante compete pelo sítio ativo da enzima, sendo estimado que $10 \%$ do sítio ativo seja ocupado por esse substrato. Portanto, em altas concentrações de L-glutamina a enzima passa a apresentar um $n_{H}=1,0$, o que caracteriza uma cinética michaeliana.

A Sc_ASPase1 apresentou um comportamento alostérico com um $n_{\mathrm{H}}$ de 2,2 utilizando somente L-asparagina como substrato. Para avaliar se a Lglutamina poderia atuar regulando o grau de cooperatividade de Sc_ASPase1, determinamos os parâmetros cinéticos na presença de L-asparagina e Lglutamina na proporção de 1 : 16 para cada concentração de L-asparagina (ANISHKIN et al., 2015).

A

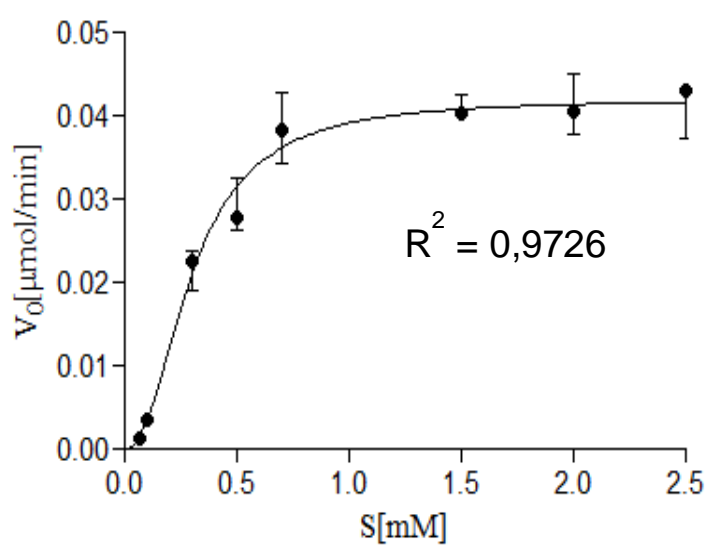

C

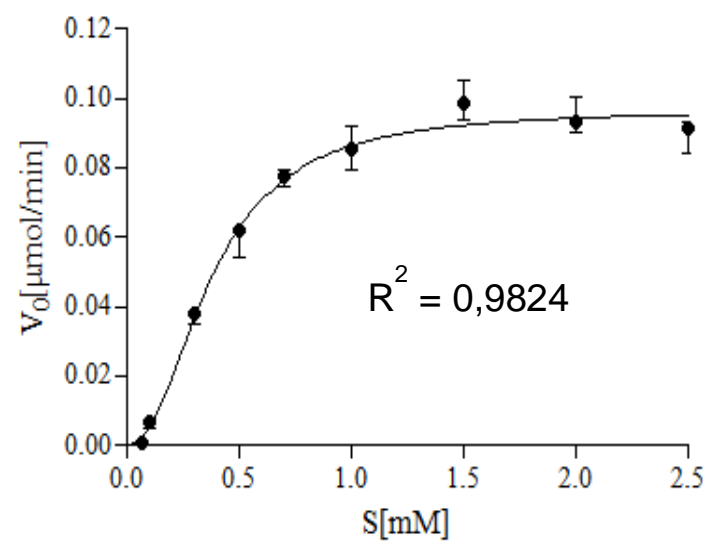

B

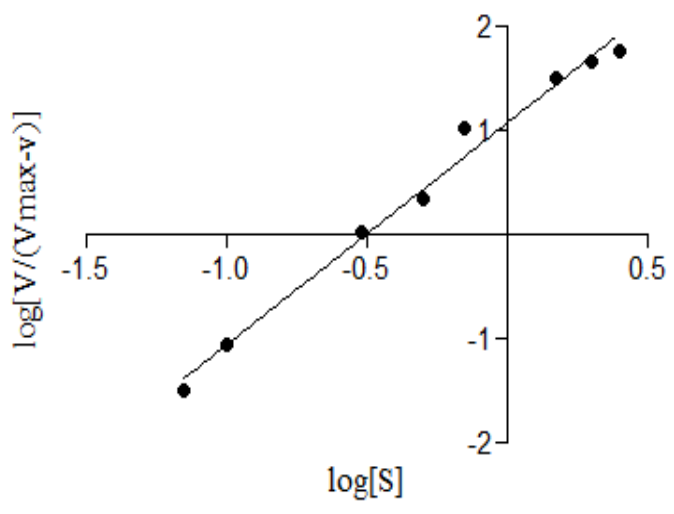

D

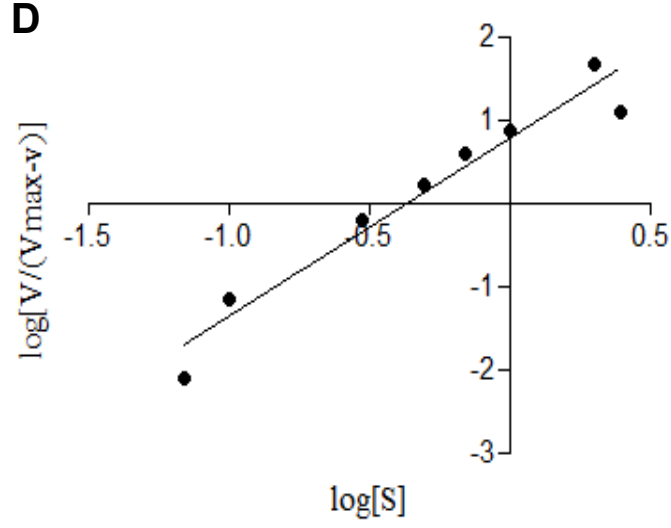

Figura 8 - Cinética de Sc_ASPase1. A: Cinética utilizando somente L-asparagina como substrato. B: Gráfico de Hill para determinação do grau de cooperatividade da cinética medida em A. C: Cinética utilizando I-asparagina e L-glutamina como substratos, na proporção de 1 : 16. D: Gráfico de Hill para determinação do grau de cooperatividade da cinética medida em C. Os gráficos de velocidade inicial $\left(\mathrm{V}_{0}\right)$ em função da concentração de substrato $(\mathrm{S})$ e os de log V/Vmax-v em função do log [S] foram obtidos pela análise dos dados no programa GraphPad Prism 5.0. Os pontos representam a média \pm desvio padrão $(n=3)$. 
A cinética foi analisada pelo ensaio acoplado de oxidação de NADH utilizando as mesmas concentrações de L-asparagina e enzima que foram descritas acima, utilizamos como controle o ensaio somente na presença de Lglutamina e descontamos a hidrólise desse aminoácido na ausência da enzima. No entanto, a adição de L-glutamina não alterou o perfil cinético da enzima (figura $8 \mathrm{C}$ e $8 \mathrm{D}$ ), ao contrário do observado para a enzima de E. coli por ANISHKIN ET AL. (2015). Os parâmetros cinéticos calculados estão apresentados na tabela 4 .

Tabela 5 - Parâmetros cinéticos de Sc_ASPase1 e Ec_ASPasell (ProspecTany)

\begin{tabular}{lccccc}
\hline Ec_ASPasel & $K_{\mathrm{m}}$ & $\begin{array}{c}\mathrm{V}_{\max } \\
\mu \mathrm{mol} / \mathrm{min}\end{array}$ & $\begin{array}{c}K_{\text {cat }} \\
\mathrm{s}^{-1}\end{array}$ & $\begin{array}{c}K_{\text {cat }} / K_{\mathrm{m}} \\
\mathrm{M} / \mathrm{s}\end{array}$ & $n_{\mathrm{H}}$ \\
\hline L-asparagina & $120 \pm 9$ & $0,032 \pm 0,00061$ & $134 \pm 2$ & $1,1 \times 10^{6}$ & $1,1 \pm 0,1$ \\
\hline Sc_ASPase1 & $K_{0,5}$ & $\mathrm{~V}_{\max }$ & $K_{\text {cat }}$ & $K_{\text {cat }} / K_{0,5}$ & $n_{\mathrm{H}}$ \\
& $\mu \mathrm{M}$ & $\mu \mathrm{mol} / \mathrm{min}$ & $\mathrm{s}^{-1}$ & $\mathrm{M} / \mathrm{s}$ & \\
\hline L-asparagina & $75 \pm 27$ & $0,042 \pm 0,0011$ & $217 \pm 14$ & $2,9 \times 10^{6}$ & $2,2 \pm 0,3$ \\
L-asparagina & $122 \pm 31$ & $0,097 \pm 0,0023$ & $523 \pm 34$ & $4,2 \times 10^{6}$ & $2,2 \pm 0,2$ \\
+L-glutamina & & & & \\
$\begin{array}{l}\text { Os parâmetros cinéticos foram calculados por análise de regressão não-linear dos dados } \\
\text { experimentais do estado estacionário, utilizando o programa GraphPad Prism 5.0. }\end{array}$
\end{tabular}

Algumas enzimas alostéricas possuem a característica de serem inibidas pelo produto da sua reação. O produto na reação atuaria como um modulador inibindo a atividade enzimática, como uma retroalimentação negativa (GERHART, 2014; CORNISH-BOWDEN, 2014). Na hidrólise de L-asparagina catalisada pelas L-ASPases o produto formado é o L-aspartato. Por meio da determinação da atividade específica com reagente de Nessler foi analisado o potencial de inibição de Sc_ASPase1 por L-aspartato. A concentração da enzima foi variada fixando a L-asparagina em $10 \mathrm{mM}$ e adicionando $20 \mathrm{mM}$ de L-aspartato. Como mostra a figura 9, o l-aspartato não atua inibindo significativamente a atividade de Sc_ASPase1. 


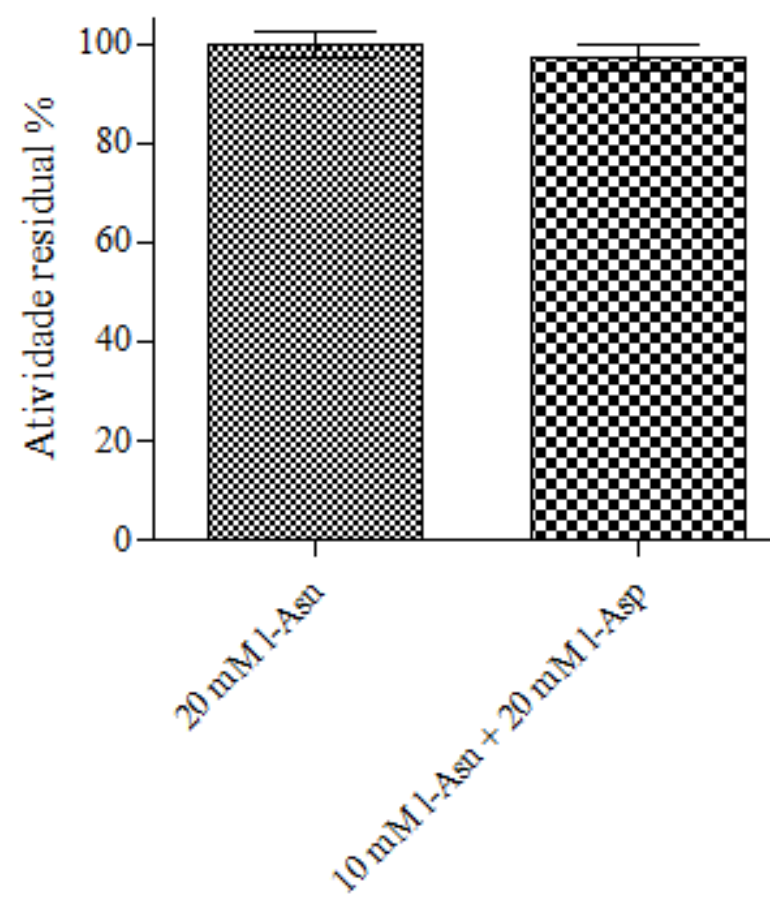

Figura 9 - Atividade específica de Sc_ASPase1 com adição de l-aspartato. $20 \mathrm{mM}$ de Lasparagina (20mM l-Asn) e com $10 \mathrm{mM}$ de L-asparagina $+20 \mathrm{mM}$ de I-aspartato ( $20 \mathrm{mM} \mathrm{I-}$ Asn + $10 \mathrm{mM}$ I-Asp). O gráfico é dado em porcentagem de atividade específica obtido com o programa GraphPad Prism 5.0. A atividade específica foi quantificada por reagente de Nessler. As barras de erro foram calculadas a partir da média \pm desvio padrão $(n=3)$.

\subsection{Mutações em Sc_ASPase1}

\subsubsection{Caracterização do sítio catalítico}

O plasmídeo $\mathrm{pET15b+ASP1}$ foi utilizado para realização das mutações para caracterização do sítio catalítico. As enzimas pertencentes à família Lasparaginase possuem motivos conservados que são constituídos por resíduos do sítio ativo (BOREK e JASKÓLSLI, 2001). O mecanismo de ação das Lasparaginases é conhecido pela elucidação do mecanismo da Ec_ASPasell, na qual os resíduos T12, T89 e K162 são descritos como importantes durante a catálise (PALM et al., 1996; GESTO et al., 2013; ANISHKIN, et al., 2015). Já a Y25 é descrita como constituinte do loop que atua estabilizando o sítio ativo para ligação do substrato (AUNG et al., 2000). 
Alinhando as sequencias primárias das isoformas bacterianas com a de Sc_ASPase1 identificamos os resíduos na levdura correspondentes aos resíduos já caracterizados nas enzimas bacterianas (figura 10A). Além da similaridade com a sequência primária, pelo modelo teórico da estrutura de Sc_ASPase1 feito pelo Prof. Dr. Marcos Antônio de Oliveira da UNESP de São Vicente - SP, é possível observar que a estrutura de Sc_ASPase1 é semelhante a de Ec_ASPasell (figura 10B). Desta forma, propusemos mutações por alanina nos resíduos T64, Y78, T141 e K215 de Sc_ASPase1 para verificarmos a perda de atividade.

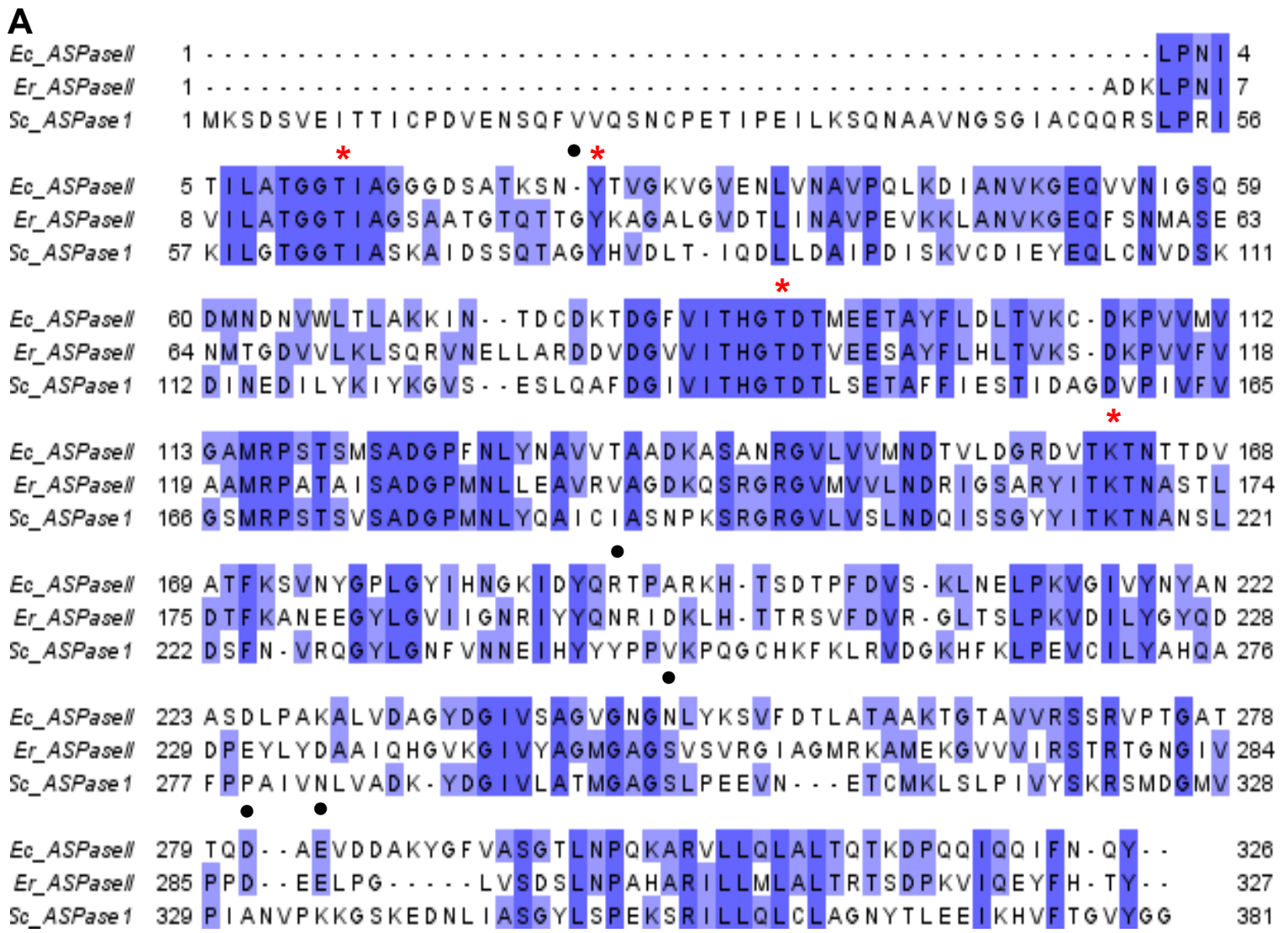


B

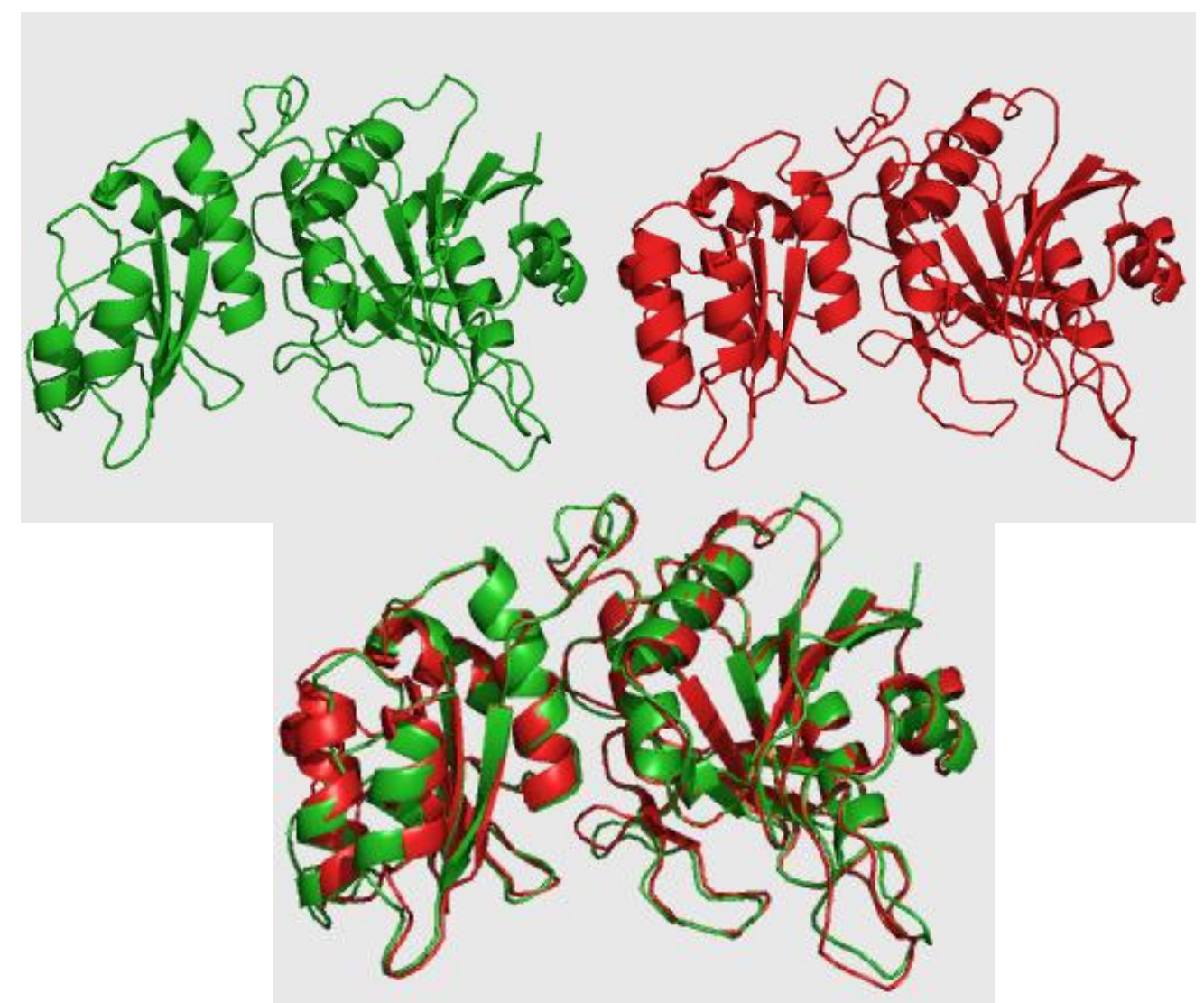

Figura 10 - A: Alinhamento das sequências das enzimas L-asparaginases. Ec_ASPasell (Lasparaginase II nativa de E. coli), Er_ASPasell. (L-asparaginase II de E. chrysanthemi) e Sc_ASPase1 (L-asparaginase 1 de Saccharomyces cerevisiae). Sequência de aminoácidos obtidos pelo site http://www.uniprot.org/; número uniprot: P00805 (Ec_ASPasell), P06608 (Er_ASPasell) e P38986 (Sc_ASPase1).. A construção do alinhamento foi feito com o programa ClustalW e gráfico gerado pelo programa JalView. Em azul estão os aminoácidos conservados entre as três isoformas de L-ASPase. O asterisco $\left(^{*}\right)$ indica os resíduos conservados correspondentes ao sítio ativo das enzimas de bactérias que foram mutados por uma alanina em Sc_ASPase1. O ponto $(\bullet)$ indica os resíduos mutados para melhoria dos parâmetros cinéticos. B:Alinhamento da estrutura do monômero de Ec_ASPasell (código Protein Data Bank - 3ECA) em vermelho, e do modelo teórico da estrutura do monômero de Sc_ASPase1 feita pelo professor Dr. Marcos Antônio de Oliveira da UNESP de São Vicente em verde.

As mutações sítio-dirigidas foram geradas usando o kit QuikChangell (Agilent); os clones mutantes foram sequenciados para confirmação da inserção da mutação. A linhagem E. coli (BL21(DE3)) foi transformada com os mutantes para expressão das proteínas, as mesmas foram purificadas por cromatografia de afinidade a metal (figura 11A). Todos os mutantes foram dessalinizados e concentrados como foi feito com a proteína selvagem. A quantificação foi feita pela Lei de Lambert-Beer, usando os coeficientes de absortividade molar das mutantes T64A, T141A, K215A é $\varepsilon=25955 \mathrm{M}^{-1} \cdot \mathrm{cm}^{-1}$ 
(como a selvagem) e para Y78A $\varepsilon=24465 \mathrm{M}^{-1} \mathrm{~cm}^{-1}$, obtidos com a ferramenta de bioinformática ProtParam (http://web.expasy.org/protparam/).

A determinação da atividade específica de cada mutante foi feita pelo reagente de Nessler. Foi utilizado no ensaio entre $0,03 \mathrm{mg}$ e 0,27 mg de proteína; as enzimas mutantes foram incubadas por 1 hora a $37^{\circ} \mathrm{C}$ com $20 \mathrm{mM}$ de L-asparagina. É possível observar uma perda de 99,9\% de atividade em relação à enzima selvagem que apresentou $195 \mathrm{U} / \mathrm{mg}$ (figura 11B), mostrando que esses resíduos são importantes para catálise enzimática. A analise estatística utilizando o teste $T$ demosntrou uma diferença estatisticamente significante das isoformas T64A, T141A, K215A em relação a Y78A. No entanto, quando as atividades específicas de T64A, T141A e K215A são comparadas entre elas não existe diferença significativa.
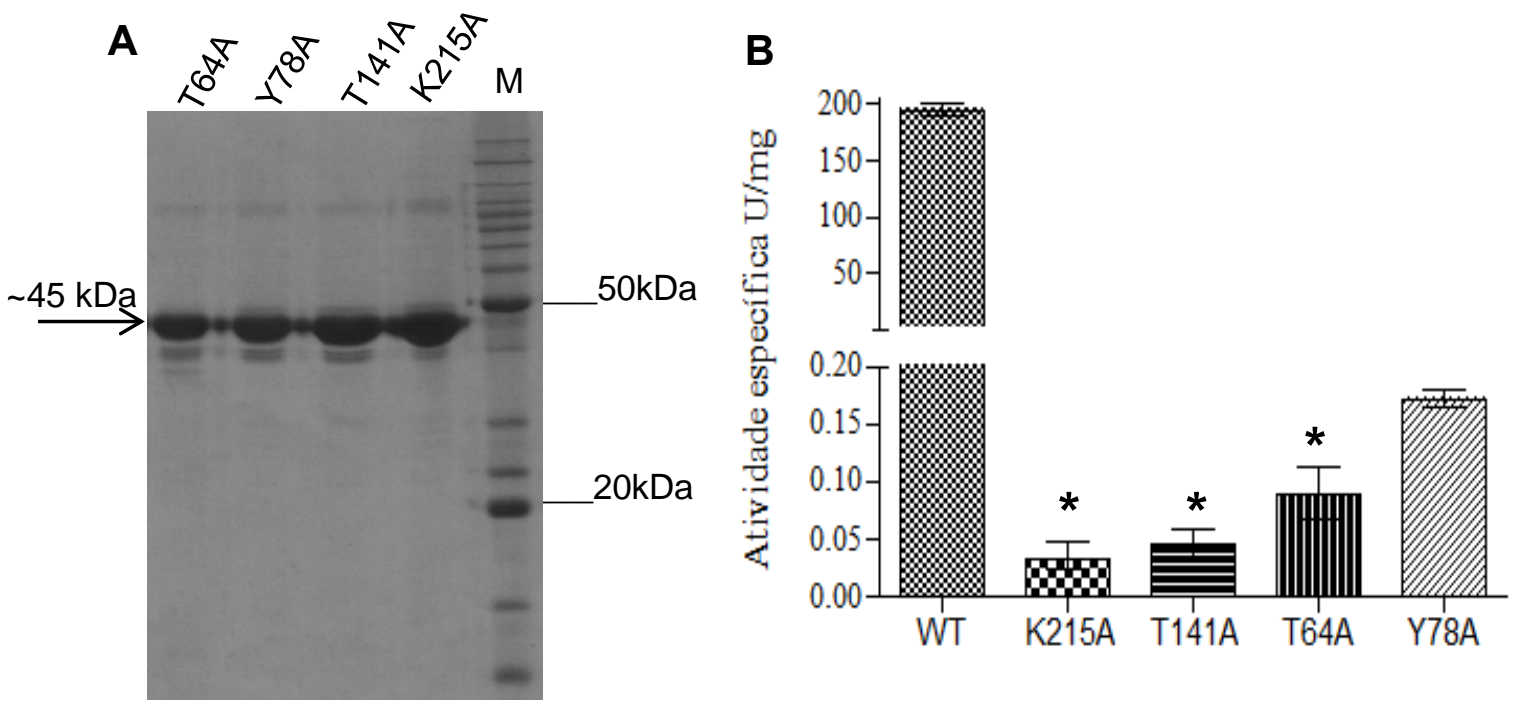

Figura 11 - Purificação e atividade das isoformas mutantes. A: Gel SDS-PAGE redutor $14 \%$ após a purificação das proteínas mutantes, o gel foi corado com Coomassie Brilliant Blue R250. M é o padrão de massa molecular BenchMarck (Invitrogen); T64A, Y78A, T141A e K215A foram eluidas com $500 \mathrm{mM}$ de imidazol da coluna de níquel. B: atividade específica dos mutantes do sítio ativo quantificada por reagente de Nessler. As barras de erro foram calculadas a partir da média \pm desvio padrão $(n=3)$. Entre os mutantes a análise estatista foi feita utilizando o teste T com o programa GraphPad Prism 5.0. ${ }^{*} p<0,05$ versus Y78A.

\subsubsection{Engenharia da proteína}


Sc_ASPase1 foi classificada como uma L-asparaginase do tipo II como as enzimas de bactérias usadas na terapêutica da LLA. Pensando na similaridade entre a enzima bacteriana e Sc_ASPase1 (figuras 10A e 10B), propusemos mutações para melhoria da atividade e dos parâmetros de Sc_ASPase1 baseadas em mutações sítio dirigidas em Ec_ASPasell e, em estudos que inferem a participação de alguns resíduos na melhoria da atividade asparaginase e diminuição da atividade L-glutaminásica da molécula bacteriana.

Os resíduos T12, N24, Y25, D281, E283 Ec_ASPasell fazem parte do sítio ativo da enzima, e as interações entre esses resíduos (N24 “D281,

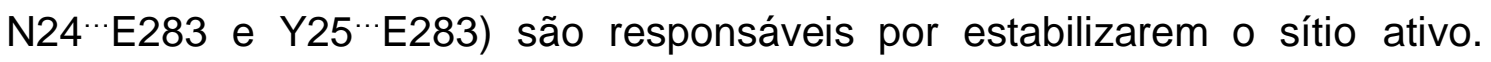
(OFFMAN et a., 2011). No entanto, para D281 e E283 de E. coli, também conservados em E. chrysanthemi, existem A331 e K335 em Sc_ASPase1, respectivamente. Com o objetivo aumentar a similaridade com L-ASPase bacteriana e possivelmente melhorar a ligação com o substrato, nós realizamos as mutações dos resíduos A331D e K335E.

Além disso, a região de sítio ativo de Sc_ASPase1 apresenta um resíduo $\mathrm{G} 77$, ausente em $E$. coli. A presença desse aminoácido poderia diminuir a atividade enzimática, ou aumentar a atividade glutaminásica, devido ao aumento da distância para interação entres os aminoácidos constituintes do sítio ativo, alterando o equilíbrio da flexibilidade e estabilidade do loop. Para verificar essa alteração retiramos o resíduo G77.

Offman et al. (2011) levantaram a hipótese de que ao substituir um aminoácido volumoso $(\mathrm{R})$ por um menor (S), o sítio ativo ficaria mais compacto e, como a L-glutamina é maior que a L-asparagina, isso dificultaria a atividade glutaminásica. De fato, o grupo demonstrou que mutações N24A e R195S na Ec_ASPasell diminuem a atividade de L-glutaminase em aproximadamente $50 \%$, mas não alteram a atividade de L-asparaginase nem o $\mathrm{IC}_{50}$ em relação às células tumorais in vitro quando comparadas à proteína selvagem. Nós realizamos a mutação Y243S em Sc_ASPase1, resíduo correspondente a R195, para diminuição da possível atividade L-glutaminásca. O resíduo correspondente ao N24 na bactéria já é uma Alanina em Sc_ASPase1, portanto, foi mantido. 
Segundo Derst et al. (2000), as enzimas que possuem uma alta atividade de L-glutaminase apresentam uma serina na posição 248. Em E. coli esse resíduo é composto por uma asparagina. Para E. chrysanthemi, que possui uma atividade de L-glutaminase maior, há uma serina. Em Sc_ASPase1 também existe uma serina, o que poderia contribuir para um aumento na atividade de L-glutaminase. Assim, nós substituímos esse aminoácido por uma asparagina $(\mathrm{S} 301 \mathrm{~N})$, como é na isoforma de E. coli. Os resíduos de Sc_ASPase1, correspondentes aos resíduos das enzimas de bactérias, que foram mutados estão representados na figura 10A.

Os iniciadores desenhados para os mutantes A331D, K335E, $\triangle \mathrm{G} 77$, Y243S e S301N estão relacionados na tabela 3. A linhagem $E$. coli (BL21(DE3)) foi transformada com os mutantes para expressão das proteínas, as mesmas foram purificadas por cromatografia de afinidade a metal (figura 12A). Todas as enzimas mutantes foram dessalinizadas e concentradas como foi feito com a proteína selvagem. A quantificação foi feita pela Lei de LambertBeer, usando os coeficientes de absortividade molar das mutantes A331D, K335E, $\triangle \mathrm{G} 77$ e S301N é $\varepsilon=25955 \mathrm{M}^{-1} . \mathrm{cm}^{-1}$ (como a selvagem) e para Y243S $\varepsilon=24465 \mathrm{M}^{-1} \mathrm{~cm}^{-1}$, obtidos com a ferramenta de bioinformática ProtParam (http://web.expasy.org/protparam/).

A determinação da atividade específica para hidrólise de L-asparagina de cada mutante foi feita com o reagente de Nessler. Foi utilizado no ensaio entre 0,09 $\mu \mathrm{g}$ e $90 \mu \mathrm{g}$ de proteína; as enzimas mutantes foram incubadas por 20 minutos a $37{ }^{\circ} \mathrm{C}$ com $20 \mathrm{mM}$ de L-asparagina. Para todos os mutantes houve uma diminuição da atividade em relação a Sc_ASPase1 selvagem (figura 12B). Para determinação da atividade específica para hidrólise de Lglutamina e dos parâmetros cinéticos, foi realizado o ensaio acoplado de oxidação de $\mathrm{NADH}$, como realizado para Sc_ASPase1. Para a cinética utilizamos $0,00036 \mathrm{mg}$ das isoformas mutantes variando a concentração de substrato. Os parâmetros cinéticos estão relacionados na tabela 6 .

Nenhum mutante apresentou atividade L-glutaminásica detectável. Os mutantes não apresentaram melhoria nos parâmetros cinéticos, as isoformas apresentam valores dentro do erro experimental em comparação com Sc_ASPase1 selvagem. A atividade específica para L-asparagina dos mutantes 
é inferior em relação à enzima selvagem. Os gráficos da atividade específica e cinética estão demonstrados no anexo $\mathrm{C}$.

A

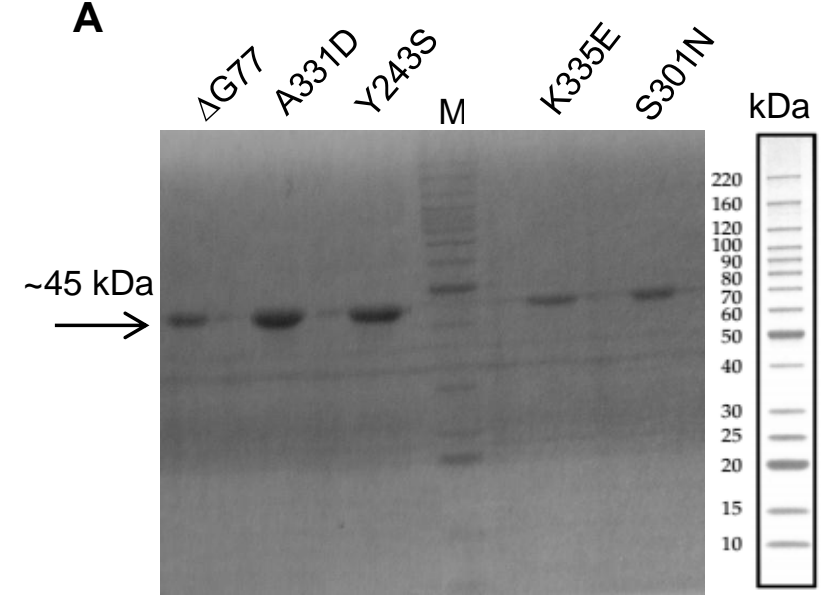

B

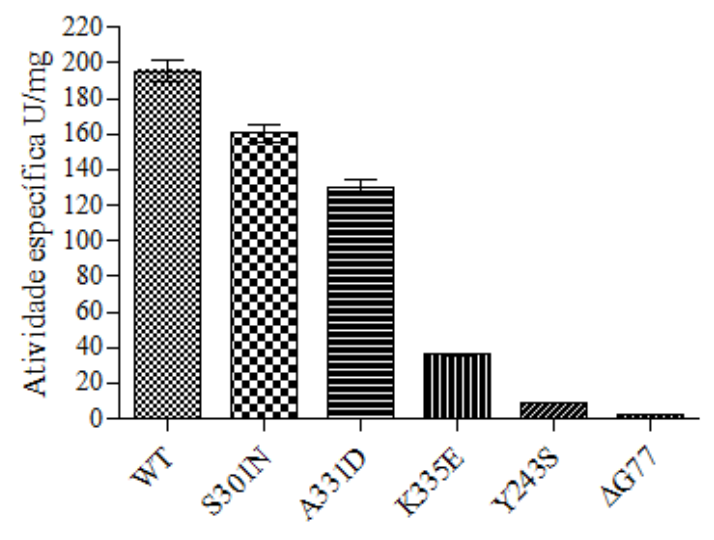

Figura 12 - Purificação e atividade específica das isoformas mutantes. A: Gel SDS-PAGE redutor $14 \%$ após a purificação das proteínas mutantes, o gel foi corado com Coomassie Brilliant Blue R-250. M é o padrão de massa molecular BenchMarck (Invitrogem); A331D, K335E, $\Delta \mathrm{G} 77$, Y243S e S301N foram eluidas com $500 \mathrm{mM}$ de imidazol da coluna de níquel. B: Atividade específica dos mutantes do sítio ativo quantificada por reagente de Nessler. As barras de erro foram calculadas a partir da média \pm desvio padrão $(n=3)$.

Tabela 6 - Parâmetros cinéticos das isoformas mutantes de Sc_ASPase1.

\begin{tabular}{lccccc}
\hline Mutante & $K_{0,5}$ & $\begin{array}{c}\mathrm{V}_{\max } \\
\mu \mathrm{Mol} / \mathrm{min}\end{array}$ & $\begin{array}{c}K_{\text {cat }} \\
\mathrm{s}^{-1}\end{array}$ & $\begin{array}{c}K_{\text {cat }} / K_{0,5} \\
\mathrm{M} / \mathrm{s}\end{array}$ & $n_{\mathrm{H}}$ \\
\hline WT & $75 \pm 27$ & $0,042 \pm 0,0011$ & $217 \pm 14$ & $2,9 \times 10^{6}$ & $2,2 \pm 0,3$ \\
A331D & $183 \pm 30$ & $0,085 \pm 0,0019$ & $216 \pm 9$ & $1,2 \times 10^{6}$ & $1,7 \pm 0,1$ \\
S301N & $124 \pm 46$ & $0,036 \pm 0,0013$ & $100 \pm 7$ & $8,1 \times 10^{5}$ & $2,2 \pm 0,3$ \\
$\Delta$ G77 & $\mathrm{n} / \mathrm{d}$ & $\mathrm{n} / \mathrm{d}$ & $\mathrm{n} / \mathrm{d}$ & $\mathrm{n} / \mathrm{d}$ & $\mathrm{n} / \mathrm{d}$ \\
K335E & $109 \pm 24$ & $0,022 \pm 0,00044$ & $62 \pm 4$ & $5,7 \times 10^{5}$ & $2,2 \pm 0,2$ \\
Y243S & $\mathrm{n} / \mathrm{d}$ & $\mathrm{n} / \mathrm{d}$ & $\mathrm{n} / \mathrm{d}$ & $\mathrm{n} / \mathrm{d}$ & $\mathrm{n} / \mathrm{d}$
\end{tabular}

Os parâmetros cinéticos foram calculados por análise de regressão não-linear dos dados experimentais do estado estacionário, utilizando o programa GraphPad Prism 5.0. $\mathrm{n} / \mathrm{d}$ - valores não detectados. 


\subsection{Construção de Asp1p+53}

A deleção dos 52 aminoácidos da região $N$-terminal aumenta a similaridade com as enzimas bacterianas e, poderia ajudar a reduzir uma possível imunogenicidade causada pelo tamanho da molécula. Sc_ASPase1 truncada (Asp1p+53) apresenta os primeiros 52 aminoácidos deletados da sua estrutura (figura 13), a construção de $p E T 15 b+A s p 1 p+53$ clonada em E. coli (DH5 $\alpha)$ foi confirmada por sequenciamento. Utilizando a ferramenta de bioinformática ProtParam (http://web.expasy.org/protparam/), previmos que 0 peso da Asp1p+53 com a cauda de His-Tag seria de aproximadamente 38 kDa.

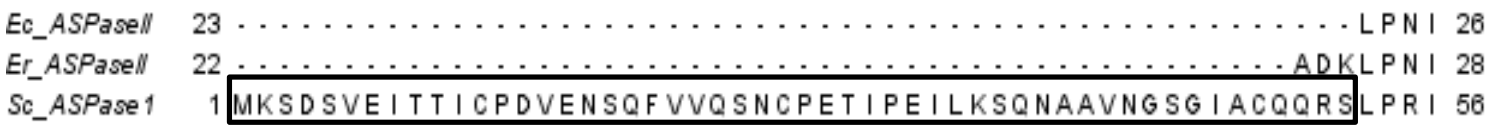

Figura 13 - Alinhamento do inicio da sequencia de aminoácidos de Sc_ASPase1 com as enzimas bacterianas sem o peptídeo sinal. Proteína madura L-ASPase II de E. coli (Ec_ASPasell) iniciando no resíduo 23; proteína madura L-ASPasell de E. chrysanthemi (Er_ASPasell) iniciando no resíduo 22; e L-asparaginase1 de S. cerevisiae (Sc_ASPase1). Destacado no quadro preto estão os 52 primeiros aminoácidos de Sc_ASPase1 que foram subtraídos para construção da proteína truncada (Asp1p+53).

$O$ primeiro teste de expressão foi feito utilizando a linhagem de $E$. coli (BL21(DE3)) em três condições. Entretanto, em todas as condições testadas a proteína permaneceu na fração insolúvel (figura 14).

A produção de agregados insolúveis pode ocorrer por diversos mecanismos (PHILO e ARAKAWA, 2009; LEBENDIKER e DANIELI, 2014). Proteínas recombinantes expressas em grandes concentrações em bactérias tendem a se acumular e se desdobrar formando agregados (GOPAL \& KUMAR, 2013). As propriedades intrínsecas da proteína, fatores de expressão e condições de purificação podem interferir no dobramento correto da proteína (LEBENDIKER e DANIELI, 2014). 
A

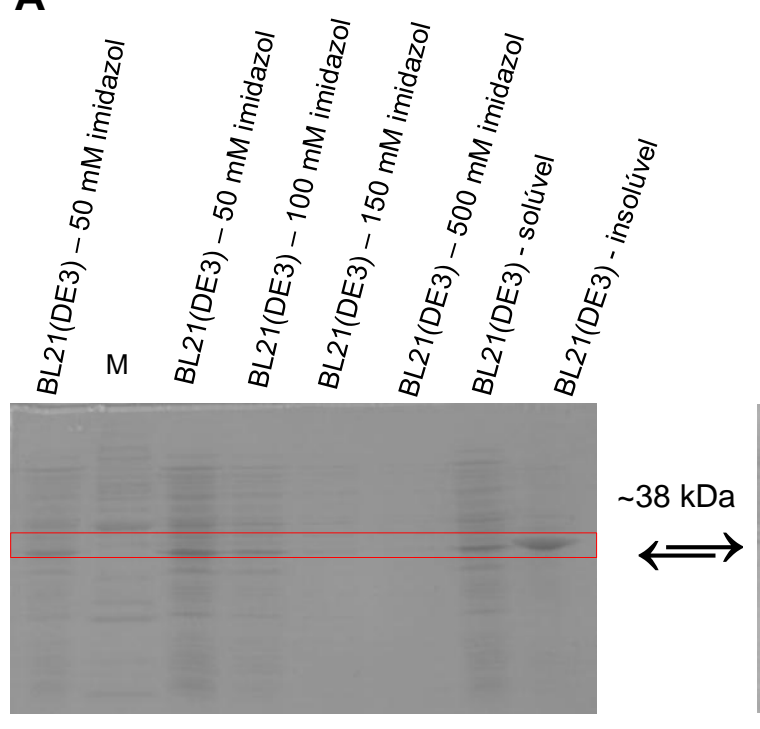

B

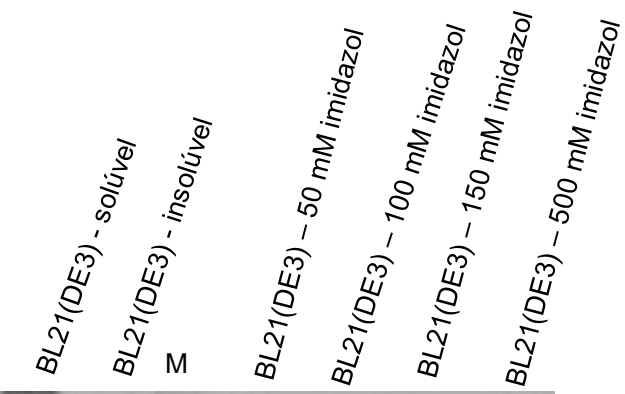

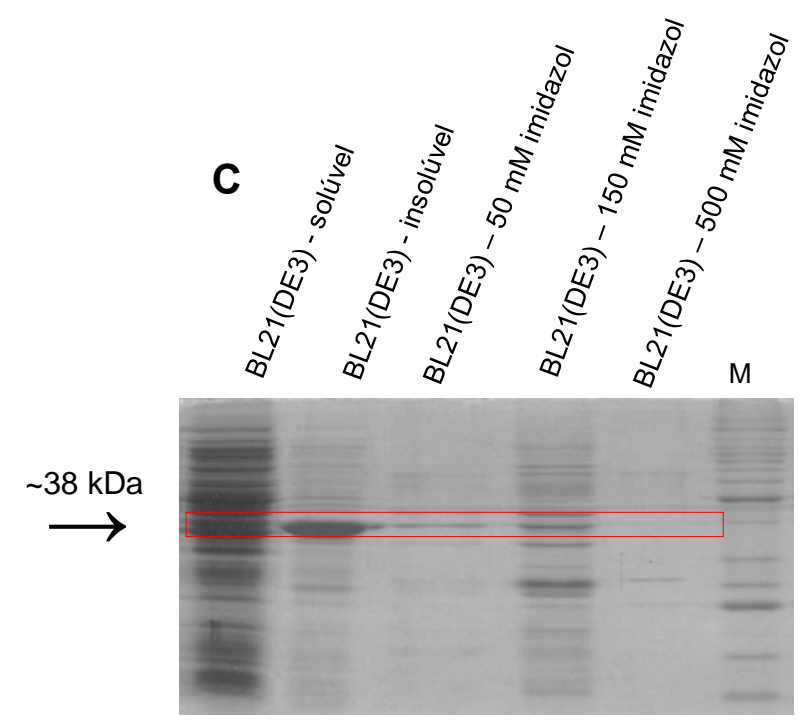

Figura 14 - Gel SDS-PAGE 14\% da expressão de Asp1p+53 em E. coli BL21(DE3). M. é o padrão de massa molecular (BenchMark), no pellet obtido após a centrifugação do lisado celular está a fração insolúvel da proteína e as demais amostras nos géis são as frações coletadas na purificação do extrato proteico. A: Pré-inóculo, inóculo e indução a $37^{\circ} \mathrm{C} \mathrm{com} 1$ $\mathrm{mM}$ de IPTG por 3h. B: Pré-inóculo e inóculo a $37^{\circ} \mathrm{C}$ e indução a $20^{\circ} \mathrm{C}$ com $0,5 \mathrm{mM}$ de IPTG por 16h. C: Pré-inóculo, inóculo e indução a $20^{\circ} \mathrm{C}$ com $0,5 \mathrm{mM}$ de IPTG por $16 \mathrm{~h}$. A seta indica a banda correspondente a $38 \mathrm{kDa}$. Em vermelho estão destacadas as frações de Asp1p+53.

Na tentativa de diminuir a formação de agregados insolúveis, realizamos teste de expressão nas linhagens AD494, BL21pLysS (DE3), C43 (DE3), Rosetta (DE3), Origami (DE3) e Arctic (DE3). Três condições diferentes de expressão para cada linhagem foram testadas: $0 \mathrm{mM}$ de IPTG por 3 horas a 37 ${ }^{\circ} \mathrm{C}, 1 \mathrm{mM}$ de IPTG por 3 horas a $37^{\circ} \mathrm{C}$ e $0,1 \mathrm{mM}$ de IPTG overnight a $20{ }^{\circ} \mathrm{C}$. Para a linhagem Arctic foram testadas $0 \mathrm{mM}, 0,1 \mathrm{mM}$ e $1 \mathrm{mM}$ de IPTG overnight a $12^{\circ} \mathrm{C}$. 
A linhagem AD494 é mutante para o gene $\operatorname{tr} x B$ (tioredoxina redutase) e a linhagem Origami (DE3) é mutante para trxB e gsr (glutationa redutase). Esses genes codificam enzimas responsáveis pela quebra de pontes dissulfeto no citoplasma, tornando-o mais propício para correta formação de pontes dissulfeto durante o enovelamento proteico (catalogo NOVAGEN, 2003). A BL21pLysS (DE3) contém o plasmídeo que expressa baixos níveis de T7lisozima, diminuindo o background de expressão de genes sobre o controle do forte promotor viral T7, evitando assim escapes promotores na ausência de indutor IPTG (CASALI, 2003). A linhagem Rosetta (DE3) contem tRNAs para códons raros em E. coli, possibilitando o aumento da expressão de proteínas de eucarioto que contém esses códons raros (catalogo NOVAGEN, 2003). A Arctic (DE3) é uma linhagem desenvolvida para expressão de proteínas insolúveis, possui a expressão de chaperonas em baixas temperaturas facilitando o enovelamento e, assim, o aumento da solubilidade (manual ALIGENT-TECHNOLOGIES, 2010). Já a linhagem C43 (DE3) foi selecionada com base na sua alta resistência a proteínas tóxicas para o hospedeiro (DUMON-SEIGNOVERT et al., 2004).

Após a expressão as células foram lisadas com BugBuster e separadas as frações solúvel e insolúvel por centrifugação. Todas as amostras foram submetidas à SDS-PAGE para avaliação da expressão (figura 15).

Somente as linhagens AD494, BL21pLysS (DE3), C43 (DE3) e Rosetta (DE3) apresentaram uma banda correspondente a $38 \mathrm{kDa}$ nas frações solúveis das três condições testadas. As frações solúveis dessas linhagens foram submetidas à purificação por afinidade a metal em coluna de níquel. Entretanto, a banda correspondente a $38 \mathrm{kDa}$ foi eluida no tampão de lavagem com $50 \mathrm{mM}$ de imidazol (figura 16). 

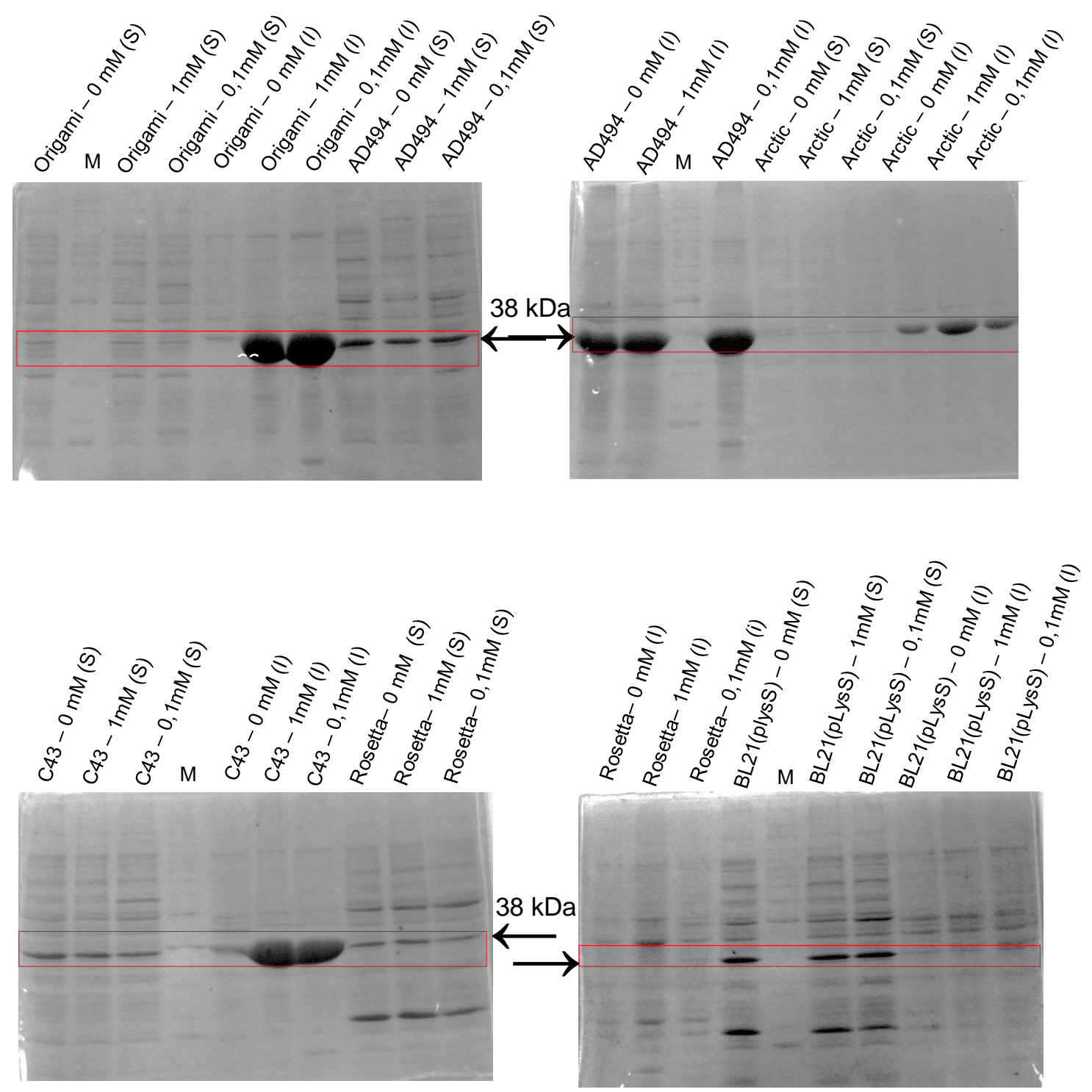

Figura 15 - Gel redutor SDS-PAGE 14\% mostrando a expressão de Asp1p+53 em E. coli AD494, BL21pLysS (DE3), C43 (DE3), Rosetta (DE3), Origami (DE3) e Arctic (DE3). As frações solúvel e insolúvel da expressão de Asp1p+53 nas linhagens AD494, BL21pLysS (DE3), C43 (DE3), Rosetta (DE3), Origami (DE3) e Arctic (DE3) com 0 mM, 0,1 mM e 1 mM de IPTG. O gel foi corado com Coomassie Brilliant Blue R-250. M é o padrão de massa molecular BenchMarck (Invitrogen); (I) indica fração insolúvel e (S) fração solúvel dos lisados proteicos clarificados. A seta indica a banda correspondente a $38 \mathrm{kDa}$. Em vermelho estão destacadas as frações de Asp1p+53. 


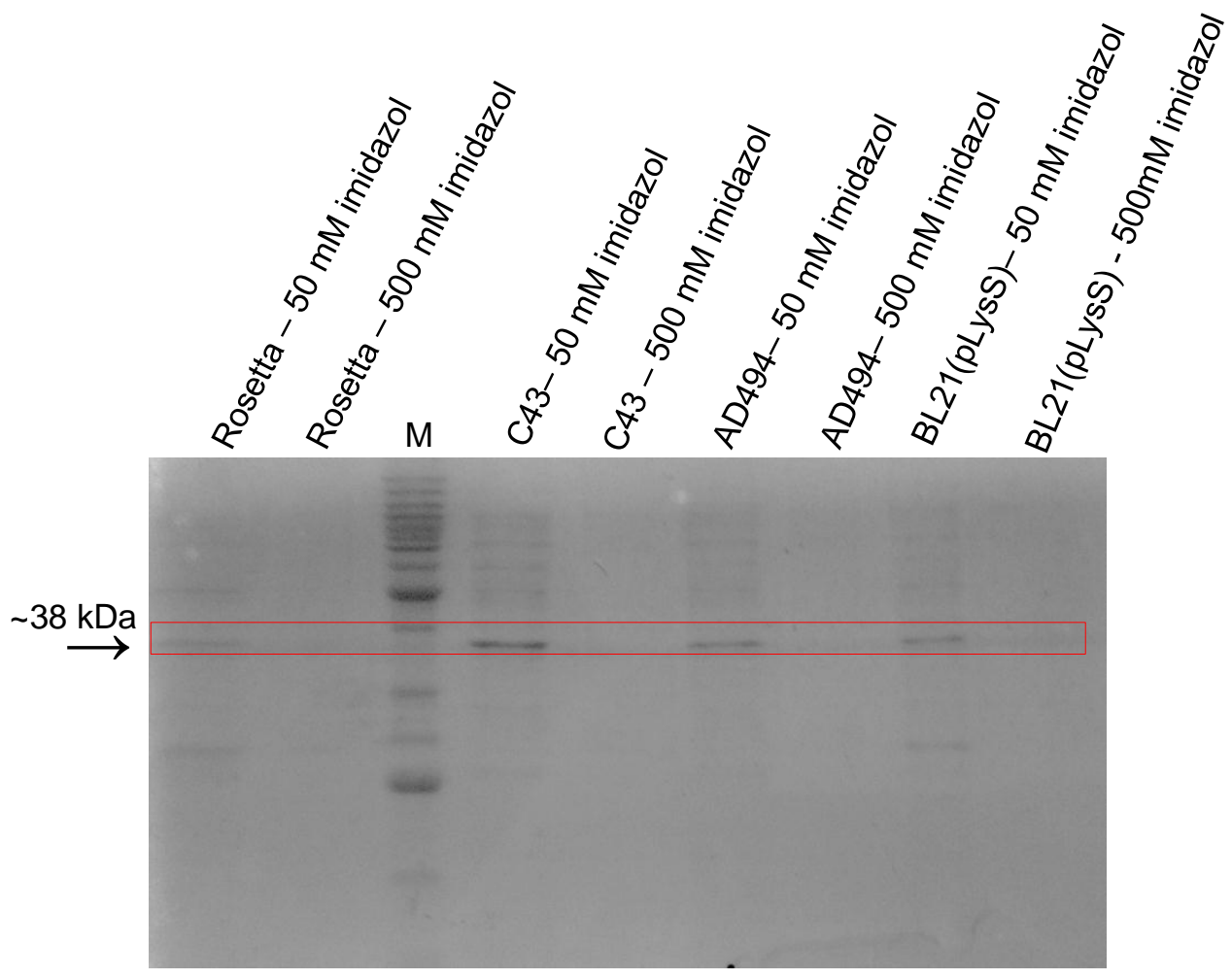

Figura 16 - Gel redutor SDS-PAGE $14 \%$ da purificação de Asp1p+53. Frações solúveis da expressão de Asp1p+53 nas linhagens AD494, BL21pLysS(DE3), C43 (DE3) e Rosetta(DE3) purificadas na coluna de níquel. As frações foram lavadas com $50 \mathrm{mM}$ de imidazol e eluidas com $500 \mathrm{mM}$ de imidazol . O gel foi corado com Coomassie Brilliant Blue R-250. M é o padrão de massa molecular BenchMarck (Invitrogem); A seta indica a banda correspondente a $38 \mathrm{kDa}$. Em vermelho estão destacadas as frações de Asp1p+53.

\subsection{Citotoxicidade}

Um ensaio preliminar utilizando as linhagens leucêmicas MOLT-4 e Reh foi feito para testar o potencial citotóxico de Sc_ASPase1. Ambas as linhagens são células de leucemia linfoblástica aguda, a primeira é derivada de linfócitos T e a segunda de linfócitos B. A linhagem Reh é considerada resistente ao tratamento com L-ASPase, pois possui níveis de expressão de ASNS (HERMANOVA, et al., 2012). Já a MOLT-4 é descrita como uma linhagem sensível a L-ASPase, porém, após seis semanas de tratamento é observada aumento na expressão de ASNS e, consequentemente a resistência à enzima (ASLANIAN, FLETCHER e KILBERG, 2001). Como controle, utilizamos a linhagem de células endoteliais saudáveis da veia umbilical humana HUVEC (www.atcc.org/). 
As células foram incubas com $10 \mathrm{U} / \mathrm{mL}$ de Sc_ASPase 1 ou Ec_ASPasell (Prospec-Tany) por 24, 48 ou 72 horas para HUVEC e Reh, e somente por 72 horas para linhagem MOLT-4. As células mortas foram identificadas por coloração com azul de Tripan, agente que só atravessa membranas plasmáticas lisadas. As células foram contadas em câmara de Neubauer e a viabilidade celular é dada em porcentagem com relação ao tempo de tratamento (figura 17).

\section{A Ec_ASPasell}

HUVEC

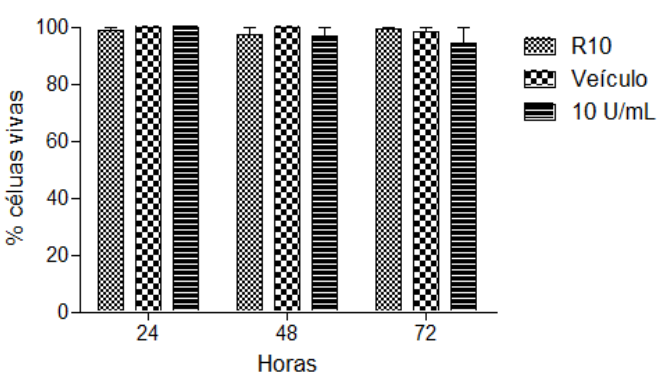

Reh

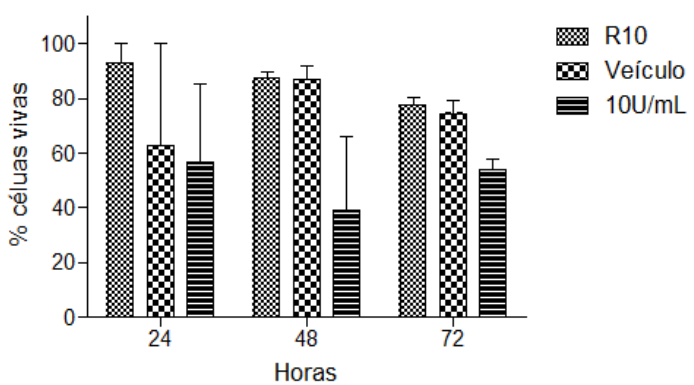

MOLT-4

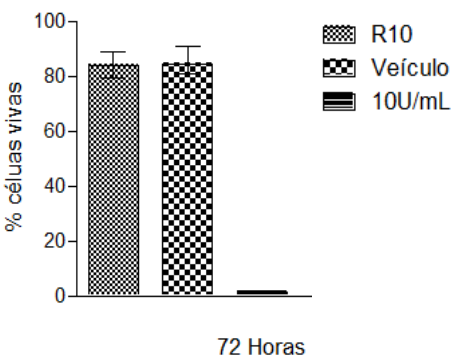

B Sc_ASPase1

HUVEC

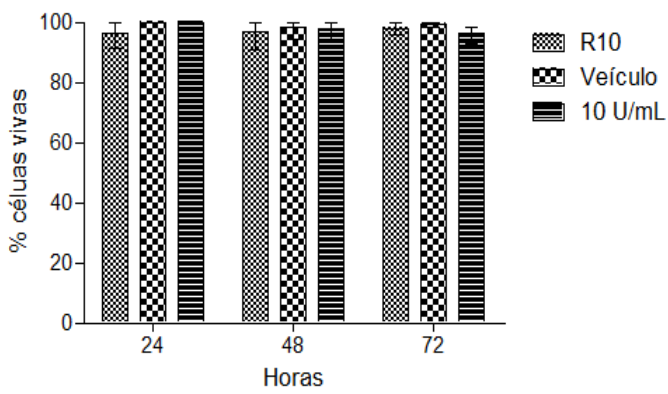

Reh

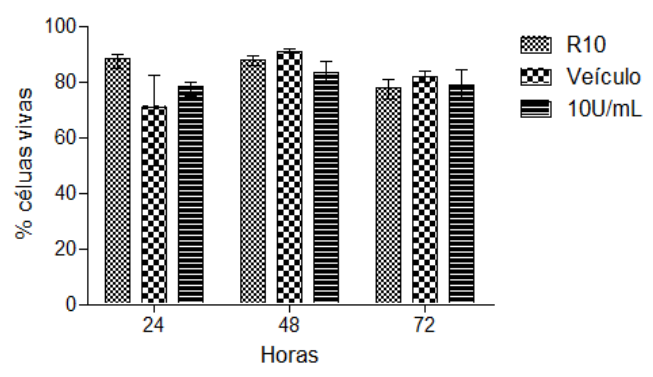

MOLT-4

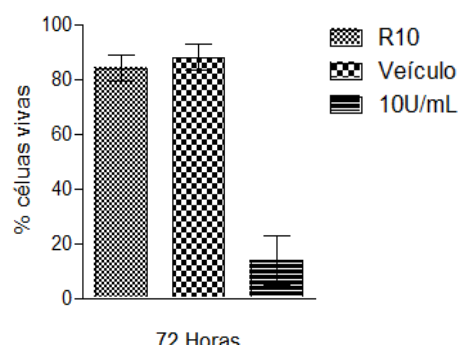

Figura 17 - Ensaio de citotoxicidade com as enzimas Sc_ASPase1 e Ec_ASPasell. Viabilidade celular (\%) das linhagens HUVEC, Reh e MOLT-4 tratadas com $10 \mathrm{U} / \mathrm{mL}$ de Ec_ASPasell ou Sc_ASPase, R10 representa as células só com a adição de meio de cultura. Veículo representa a células em meio cultura com a adição de $30 \mu \mathrm{L}$ de tampão $50 \mathrm{mM}$ fosfato de sódio pH 7,4 (tampão de diluição da enzima). B: Veículo representa a células em meio cultura com a adição de $30 \mu \mathrm{L}$ de tampão $20 \mathrm{mM}$ tris-HCL pH 8,8 (tampão de diluição da enzima). As barras de erro foram calculadas a partir da média \pm desvio padrão $(n=3)$ utilizando o programa Graphpad Prism 5.0. 
A enzima de $E$. coli não apresenta toxicidade para célula saudável. Para a linhagem resistente Reh, tratada com $10 \mathrm{U} / \mathrm{mL}$, a análise estatística utilizando o teste $T$ não demonstrou diferença significativa entre o controle e as células com tratamento nos três tempos, mostrando que Ec_ASPasell não é toxica para essa linhagem. No entanto, para linhagem MOLT-4 aproximadamente 100\% das células são mortas nessa concentração (figura 17A).

Já Sc_ASPase1, assim como a enzima bacteriana, não é toxica para linhagem HUVEC, e também não apresenta grau de toxicidade nessa concentração para linhagem Reh. No tratamento com a linhagem sensível, MOLT-4, a enzima mostrou um potencial citotóxico de 85\% (figura 17B).

Esses resultados são preliminares, os ensaios serão repetidos para confirmação do potencial citotóxoco Sc_ASPase1. Serão utilizadas diferentes concentrações de enzima (Sc_ASPase1 e Ec_ASPasell) por 24, 48 e 72 horas para as linhagens controle HUVEC e MOLT-4 que apresentou sensibilidade a Sc_ASPase1. 


\section{DISCUSSÃO}

Produzimos Sc_ASPase1 por expressão heteróloga e obtivemos a enzima com grau elevado de pureza (figura 6), por uma única etapa cromatográfica. Sc_ASPase1 possui uma atividade especifica de 195,4 U/mg para a L-asparagina (figura 7A). Os poucos estudos realizados com Sc_ASPase1 na década de 70 relataram uma atividade específica de 0,06 U/mg (JONES e MORTIMER, 1973) e 5,4 U/mg (DUNLOP et al., 1978), a partir da enzima obtida pela produção endógena e purificada por meio de vários passos cromatográficos. A atividade específica de 195,4 U/mg para Sc_ASPase1 está dentro dos valores que encontramos no nosso laboratório para Ec_ASPasell (Prospec-Tany) de 233, 2 U/mg (anexo B) e, dentro dos valores relatados para Ec_ASPasell e Er_ASPasell, utilizadas no tratamento da LLA, de 280-1300 U/mg (NARTA et al., 2007;. OFFMAN et al., 2011) e 118$908 \mathrm{U} / \mathrm{mg}$, respectivamente (KOTZIA e LABROU, 2007;. GERVAIS e FOOTE, 2014).

Ec_ASPasell e Er_ASPasell possuem uma atividade específica para Lglutamina com valores entre $2 \%$ e $10 \%$ da sua atividade L-asparaginase (NARTA et al., 2007;. AVRAMIS, et al., 2012). A necessidade de atividade Lglutaminásica vem sendo discutida na literatura. Segundo CHAN ET AL. (2014), atividade de L-glutaminase é importante para a eficácia do tratamento em linhagens leucêmicas ASNS-positivas (que expressam asparagina sintetase), uma vez que a L-asparagina pode ser produzida a partir de Lglutamina a partir da ASNS (figura 2) (EMADI, et al., 2014). Enquanto que, para linhagens ASNS-negativas (que não expressam asparagina sintetase) apenas a atividade asparaginase é necessária (CHAN et al., 2014).

Outro estudo demonstrou que a atividade de L-glutaminase em linhagens ASNS-negativas é importante para aumentar a morte de células leucêmicas, e este efeito pode estar associado à expressão de asparagina sintetase por subclones, ou pela obtenção de L-asparagina a partir de outras células (PARMENTIER et al., 2015).

Segundo ANISHKIN ET AL. (2015), a L-glutamina é responsável por garantir a atividade asparaginase da enzima em concentrações submicromolar 
de L-asparagina, concentrações séricas que são atingidas durante o tratamento da LLA. A L-glutamina seria um modulador positivo, pois nessas concentrações a Ec_ASPasell seria incapaz reconhecer o substrato, aumentando a afinidade da enzima pela L-asparagina. Esse mecanismo de regulação justificaria a necessidade da atividade L-glutaminásica para eficácia do tratamento de células ASNS-negativas.

Não só a necessidade da presença da atividade glutamaminase, como também, a redução dessa atividade nas enzimas bacterianas vem sendo estudada com a finalidade de diminuir efeitos adversos como a neurotoxicidade e hiperamonemia causados ao longo do tratamento (NARTA et al., 2007; RAETZ e SALZER, 2010). De acordo com nossos resultados, Sc_ASPase1 apresentou uma atividade L-glutaminásica de $0,38 \%$ da sua atividade Lasparaginase (figura 7B), que é aproximadamente vinte e cinco vezes menor do que a Ec_ASPasell testada em nosso laboratório que apresentou $10 \%$ (anexo B). Essa atividade reduzida pode ser interessante para o tratamento da LLA de células ASNS-negativas, diminuindo a redução desses efeitos adversos.

O comportamento alostérico de Sc_ASPase1 (figura 8A e 8B) com um $K_{0.5}$ de $75 \mu \mathrm{M}$ e cooperatividade positiva indicada por um $n_{\mathrm{H}}$ de 2,2 (tabela 5) corroboram em parte as suposições de Dunlop et al. (1978) na primeira caracterização da enzima. O grupo sugere que Sc_ASPase1 não poderia esgotar baixos níveis de L-asparagina, relatando um $K_{\mathrm{m}}$ de $740 \mu \mathrm{M}$, dez vezes superior ao que nós demonstramos. Comparando $0 K_{0.5}$ de $75 \mu \mathrm{M}$ de Sc_ASPase1 com o $K_{\mathrm{m}}$ de $119 \mu \mathrm{M}$ de Ec_ASPasell (Prospec-Tany) que obtivemos em nosso laboratório, dentro dos nossos ensaios - considerando os erros experimentais indicados - a afinidade de Sc_ASPase1 pela L-asparagina é semelhante a de Ec_ASPasell, além dos valores de $K_{\text {cat }}$ e eficiência catalítica serem muito próximos (tabela 4).

L-ASPases alostéricas são classificadas como tipo I, tais como LASPasel de E. coli (Ec_ASPasel), que apresenta um $n_{H}$ de 2,6 e $K_{0.5}$ de 1,2 mM (YUN et al., 2007), e a L-ASPasel humana (H.sapiens_ASPasel), que tem um $n_{\mathrm{H}}$ de 3,9 e $K_{0.5}$ de 11,5 mM (KARAMITROS e KONRAD, 2014). Da mesma maneira como descrito para as enzimas de tipo I, Sc_ASPase1 é modulada somente pelo substrato para catalisar a hidrólise de L-asparagina. 
Sc_ASPase1 possui um comportamento alostérico (figura 8A e 8B) com cooperatividade positiva (tabela 5) quando incubada somente com Lasparagina. A adição de L-glutamina não alterou $0 K_{m}$ e 0 grau de cooperatividade da enzima, diferente do demonstrado por ANISHKIN ET AL. (2015) para Ec_ASPasell (figuras 9C, 9D e tabela 5). No entanto, a adição desse aminoácido aumentou o $K_{\text {cat }}$ de Sc_ASPase1 em duas vezes, indicando que a L-glutamina pode se ligar em algum sítio da enzima, sendo necessário maiores estudos.

Além disso, verificamos a possibilidade do produto da reação, o Laspartato, exercer papel inibitório durante a catálise. Como demonstrado na figura 9, o L-aspartato não tem função inibitória, pois a enzima apresentou a mesma atividade específica.

Diferentemente das enzimas tipo I, Sc_ASPase1 apresenta uma elevada afinidade pelo substrato. Essa elevada afinidade é característica das enzimas tipo II como de Ec_ASPasell e Er_ASPasell na faixa de $\mu \mathrm{M}$ (KOTZIA e LABROU, 2007; GERVAIS e FOOTE, 2014; BROOME, 1968;. DERST, HENSLING e ROHM, 2000). A afinidade pelo substrato vem sendo relacionada com a estrutura quaternária da proteína (MICHALSKA e JASKOLSKI, 2006). Enzimas do tipo II são geralmente ativas como homotetrâmeros, formado pela ligação de dois dímeros, com quatro sítios ativos idênticos sem cooperatividade (SANCHES et al., 2007). As L-ASPases tipo I têm diferentes tipos de organização quaternária: Ec_ASPasel é um tetrâmero em solução que tem sua estrutura quaternária compactada por mudanças conformacionais dos monômeros, quando o substrato se liga ao sítio alostérico (YUN et al., 2007); a L-ASPase tipo I humana é um monômero em solução, e se oligomeriza em tetrâmero quando incubada com o substrato (KARAMITROS e KONRAD, 2014.); por fim, a L-ASPase tipo I de Pyrococcus horikoshii é constituída por um homodímero constante (YAO et al., 2005).

Apesar das diferenças estruturais, L-ASPases tipo I e II têm semelhança em suas sequências de aminoácidos e seus resíduos no local do sítio ativo são conservados (BOREK e JASKÓLSLI, 2001; BONTHRON e JASKÓLSLI, 1997). O mecanismo de ação proposto para a $L$-asparaginases baseia-se no mecanismo de Ec_ASPasell. Existem três propostas de mecanismo de ação para Ec_ASPasell que discutem o papel dos resíduos T12, T89, K162 e Y25 
dentro da catalise (PALM et al., 1996; GESTO et al., 2013; ANISHKIN et al., 2015).

Alinhando as sequências de Ec_ASPasell e Er_ASPasell com Sc_ASPase1 identificamos os mesmos resíduos do sítio ativo conservados (figura 10A). As mutações nos resíduos T64, Y78, T141 e K215 por uma alanina mostraram que todos os mutantes têm uma perda significativa de atividade em comparação com a enzima selvagem. Os mutantes T64A, T141A e K215A, que possuem menor atividade, não apresentam diferença estatística entre eles. Quando comparados com Y78, que tem a atividade mais elevada, existe uma diferença estatística (figura 11B). Assim, sugere-se que os resíduos T64, T141 e K215 participam na catálise, enquanto Y78 pode ter um papel estrutural no sitio ativo da enzima como descrito para Ec_ASPasell.

Apesar da similaridade na estrutura de Ec_ASPasell e Sc_ASPase1 (figura 10B), as mutações realizadas em Sc_ASPase1 baseadas em mutações e estudos realizados para melhoria das enzimas bacterianas, relacionadas na figura 12, não apresentaram melhoria. As isoformas A331D e K335E foram propostas com o objetivo de melhorar a afinidade pelo substrato e sua atividade específica, já que a enzima havia sido descrita com um $K_{\mathrm{m}}$ de $\mathrm{mM}$ e uma baixa atividade (DUNLOP et al., 1978). Na enzima bacteriana os resíduos D281 e E283, correspondentes a A331 e K335 em Sc_ASPase1, são importantes na estabilização do sítio ativo (OFFMAN et al., 2011), no entanto observamos que essas mutações não melhoram os parâmetros cinéticos de Sc_ASPase1 (tabela 6), e diminuem sua atividade específica (figura 12B).

As mutações $\mathrm{Y} 243 \mathrm{~S}$, S301N e $\Delta \mathrm{G} 77$ foram propostas pensando na redução da possível atividade de L-glutaminase da enzima (OFFMAN et al., 2011; DESRT, HENSLING e ROHM, 2000). No entanto, nós demonstramos que Sc_ASPase1 selvagem possui uma atividade sessenta vezes menor do que a enzima bactéria. $\mathrm{Na}$ isoforma $\mathrm{S} 310 \mathrm{~N}$ não foi detectada a presença de atividade L-glutaminásica e, não houve alterações significativas na atividade Lasparaginásica (figura 12B) e nos parâmetros cinéticos (tabela 6) em relação à enzima selvagem. A perda total da atividade L-glutaminásica pode não ser interessante pensando no tratamento de linhagens ASNS-positivas de LLA (CHAN et al., 2014), mas podem ser uma alternativa para redução da toxicidade em pacientes com células ASNS-negativas . 
Os mutantes Y243S e $\Delta \mathrm{G} 77$ mostram uma perda significativa na atividade específica para L-asparagina, de aproximadamente 97\% e 95\% (figura 12B). Em Ec_ASPasell o resíduo correspondente a Y243 de Sc_ASPase1 fica próximo ao sítio ativo (OFFMAN et al., 2011). Portanto, assim como em Ec_ASPasell, Y243 de Sc_ASPase1 pode estar localizado próximo sítio ativo e atuar na sua estabilização, o que justificaria a perda de atividade para a isoforma Y243S.

Já o resíduo G77 de Sc_ASPase1 é correspondente ao resíduo G33 de Er_ASPasell, o qual é ausente em Ec_ASPasell (figura 10A). O resíduo G33 de Er_ASPasell é constituinte do loop no sítio ativo da enzima (AGHAIPOUR, WLODAWER e LUBKOWSKI, 2001b). Por tanto, como para enzima bacteriana, G77 pode fazer parte do loop de Sc_ASPase1. A deleção desse resíduo desestabilizaria o sítio ativo, justificando a perda de atividade.

A retirada dos 52 primeiros aminoácidos de Sc_ASPase1, com o objetivo de aumentar a similaridade com as enzimas bacterianas (figura 13) e reduzir uma possível imunogenicidade causada pelo tamanho da molécula não possibilitou a produção da enzima solúvel. Foram feitos testes de expressão em sete linhagens diferentes, com alterações na temperatura, tempo de expressão e concentração de indutor, mas em todas as condições testadas a proteína continuou sendo expressa em grandes quantidades na fração insolúvel, como mostram as figuras 14 e 15.

Nas linhagens AD494, BL21pLysS (DE3), C43 (DE3) e Rosetta (DE3) foi possível observar uma banda na fração solúvel. No entanto, durante a purificação por IMAC, a proteína não se ligou a coluna de níquel (figura 16). Uma possibilidade é de que não era a proteína de interesse, já que a proteína foi expressa na mesma quantidade na presença e ausência de indutor, indicando que os 52 aminoácidos deletados de Sc_ASPase1 são importantes para manutenção da estrutura da proteína. A segunda possibilidade é de que proteína esteja dobrada de uma maneira em que a cauda de histidina não está exposta, impedindo a ligação na coluna.

Não obtivemos sucesso na obtenção de uma enzima com parâmetros superiores aos das enzimas bacterianas. No entanto, a Sc_ASPase 1 selvagem apresentou potencial antineoplásico, matando $85 \%$ das células MOLT-4 em ensaios preliminares (figura 17). Estudos realizados com L_ASPases II de 
Erwinia carotorova e Helicobacter pylori mostram que, utilizando a mesma concentração de enzima (10 U/mL), a mortalidade para células MOLT-4 é de $83 \%$ e $30 \%$, respectivamente. (PAPAGEORGIOU, et al., 2008; CAPPELLETTI, et al., 2008). Para a mesma linhagem com $10 \mathrm{U} / \mathrm{mL}$ de Ec_ASPasell a mortalidade é de 95\% (PAPAGEORGIOU, et al., 2008). Karamitros et al. (2013), demonstrou uma mortalidade para células MOLT-4 de aproximadamente 70\% para Sc_ASPase1 e de 75\% para Ec_ASPasell, para as enzimas encapsuladas e livres utilizando $5 \mathrm{U} / \mathrm{mL}$. A ausência de toxicidade de Sc_ASPase1 para células Reh (figura 18B), que são ASNS-positivas, pode ser justificada devido a baixa atividade de L-glutaminase da enzima.

Nesse primeiro ensaio, Sc_ASPase1 apresentou um potencial antileucêmico superior aos de enzimas que vem sendo caracterizadas e, com uma mortalidade próxima ao da Ec_ASPasell para células MOLT-4. Porém, é necessária a continuação dos estudos de citotoxicidade para estabelecer os parâmetros de sua toxicidade em células leucêmicas. 


\section{CONCLUSÃO}

Sc_ASPase1 possui uma atividade específica de $195 \mathrm{U} / \mathrm{mg}$ para Lasparagina, próxima dos valores das enzimas bacterianas, e uma baixa atividade glutaminásica que repesenta $0,38 \%$ da atividade L-asparaginase, 0 que pode diminuir a neurotoxicidade. Os resíduos T64-Y78-T141-K215 desempenham um papel importante na catálise enzimática. Além disso, a enzima apresentou alta afinidade pela $L$-asparagina com $K_{0.5}$ de $75 \mu \mathrm{M}$, muito menor do que o descrito pela literatura. É a primeira vez que uma enzima de perfil cinético alostérico apresenta potencial antileucêmico, sendo capaz de causar a mortalidade de $85 \%$ das células de LLA MOLT-4. Nosso trabalho indica que Sc_ASPase1 é uma enzima promissora para o tratamento da LLA. 


\section{REFERÊNCIAS BIBLIOGRÁFICAS}

AGHAIYPOUR, K.; WLODAWER, A.; LUBKOWSKI, J. Structural Basis for the Activity and Substrate Specificity of Erwinia chrysanthemi L-Asparaginase. Biochemistry, v. 40, p. 5655-5664, 2001a.

AGHAIYPOUR, K.; WLODAWER, A.; LUBKOWSKI, J. Do bacterial Lasparaginases utilize a catalytic triad Thr-Tyr-Glu?. Biochimica et Biophysica Acta, v. 1550, p.117-128, 2001b.

ANISHKIN, A. et al. Catalytic Role of the Substrate Defines Specificity of Therapeutic L-Asparaginase. J Mol Biol, p. 1-19, 2015.

ANVISA. Consulta de Produtos. Disponível em:

$<$ http://www7.anvisa.gov.br/datavisa/consulta_produto/Medicamentos/frmConsu ItaMedicamentos.asp>. Acesso em: 27 jul 2015.

ASLANIAN, A. M.; FLETCHER. B. S.; KILBERG, M. S. Asparagine synthetase expression alone is sufficient to induce L-asparaginase resistance in MOLT-4 human leukaemia cells. Biochem. J., v. 357, n. 1, p. 321-328, 2001.

ASSELIN, B.; RIZZARI, C. Asparaginase pharmacokinetics and implications of therapeutic drug monitoring. Leukemia \& Lymphoma, v. 1, n. 1, p. 1-8, 2015.

AUNG, $\mathrm{H}$. et al. Dynamics of a mobile loop at the active site of Escherichia coli asparaginase. Biochimica et Biophysica Acta, v. 1481, p. 349-359, 2000.

AVRAMIS, V. I. Asparaginases: Biochemical Pharmacology and Modes of Drug Resistance. Anticancer Research, v.32, p. 2423-2438, 2012.

BALCÃO, V. M. et al. Structural and functional stabilization of L-Asparaginase via multisubunit immobilization onto highly activated supports. Biotechnol., v. 17, n. 3, p. 537-542, 2001.

BÖHM, G.; MURH, R.; JAENICKE, R. Quantitative analysis of protein far UV circular dichroism spectra by neural networks. Protein Eng, v. 5, n. 3, p. 191195, 1992.

BONTHRON, D.T.; JASKÓLSLI, M. Why a "benign" mutation kills enzyme activity. Structure-based analysis of the A176V mutant of Saccharomyces cerevisiae L-asparaginase I. Acta Biochimica Polonica, v. 44, n. 3, p. 491504, 1997.

BOREK, D.; JASKÓLSLI, M. II. Acta Biochimica Polonica, v. 48, n. 4, p. 893902, 2001.

BRAGA, P.E.; LATORRE, M.R.D.O.; CURADO, M.P. Câncer na infância: análise comparativa da incidência, mortalidade e sobrevida em Goiânia (Brasil) e outros países. Cad. Saúde Pública, v. 18, n. 1, p. 33-44, 2002. 
BRISSON, G.D; ALVES, R.L.; POMBO-DE-OLIVEIRA, M.S. Genetic susceptibility in childhood acute leukaemias: a systematic review. Ecancer, v. 9, n. 539, p. 1-28, 2015.

BROOME, J.D. Evidence that the L-asparaginase activity in guinea pig serum is responsible for antilymphoma effects. Nature, v.191, p. 1114-1115, 1961.

BROOME, J.D. Factors which may influence the effectiveness of Lasparaginase as tumor inhibitors. British Journal of Cancer, v. 22, n. 3, p. 595-602, 1968.

BURKE, P.M.; DOUER, D. Acute Lymphoblastic Leukemia in Adolescents and Young Adults. Acta Haematologica, v. 132, n. 1, p. 264-273, 2014.

CAPPELLETTI, D. et al. Helicobacter pylori L-asparaginase: A promising chemotherapeutic agent. Biochemical and Biophysical Research Communications, v. 377, n. 4, p. 1222-1226, 2008.

CASALE, T.D.; SOLLITI, P., CHESNEY, R.H. Cytoplasmic L-Asparaginase: Isolation of a Defective Strain and Mapping of ansA. Journal of Bacteriology, v. $154, \mathrm{n}, 1, \mathrm{p}$, 513-515, 1983.

CASALI, N. Escherichia coli Host Strains; Methods in Molecular Biology; v. 235; p. 27-48; 2003.

CEDAR, H.; SCHWARTZ, J.H. Localization of the Two L-Asparaginases in Anaerobically Grown Escherichia coli. J. Biol. Chem., v. 242, n. 16, p. 37533755, 1967.

CHAN, W. K. The glutaminase activity of L-asparaginase is not required for anticancer activity against ASNS-negative cells. Blood, v. 123, n. 23, p. 35963606, 2014.

CONDUTAS DO INCA/MS. Leucemias Agudas na Infância e Adolescência. Revista Brasileira de Cancerologia, v. 47, n. 3, p. 245-247, 2001.

CONDUTAS DO INCA/MS. Leucemia Linfóide Aguda em Adulto. Revista Brasileira de Cancerologia, v. 48, n. 3, p. 309-312, 2002.

CORNISH-BOWDEN, A. Understanding allosteric and cooperative interactions in enzymes. FEBS Journal, v. 281, n. 1, p. 621-632, 2014.

CORTIJO-CASCAJARES, S.; JIMÉNEZ-CEREZO, M.J.; TEJADA H. Revisión de las reacciones de hipersensibilidad a antineoplásicos. Farmacia Hospitalaria, v. 36, p. 148-158, 2012.

DAVIS, A.S.; VIEIRA, A.J.; MEAD, M.D. Leukemia: An Overview for Primary Care. American Family Physician, v. 89, n. 9, p. 731-738, 2014. 
DERST, C.; HENSLING, J.; ROHM, K. Engineering the substrate specificity of Escherichia coli asparaginase II. Selective reduction of glutaminase activity by amino acid replacements at position 248. Protein Science, v. 9, p. 2009-2017, 2000.

DOUER, D. Is asparaginase a critical component in the treatment of acute lymphoblastic leukemia?. Best Practice \& Research Clinical Haematology, v. 21, p. 647-658, 2008.

DUMON-SEIGNOVERT, L.; CARIOT, G.; VUILLARD, L. The toxicity of recombinant proteins in Escherichia coli: a comparison of overexpression in BL21(DE3), C41(DE3), and C43(DE3); Protein Expression and Purification; v. 37; p. 203-206, 2004.

DUNLOP, et al. Characterization of two forms of asparaginase in Saccharomyces cerevisiae. The Journal of Biological Chemistry, v. 253, p. 1297-1304, 1978.

EMADI, A.; ZOKAEE, H.; SAUSVILLE, E.A. Asparaginase in the treatment of non-ALL hematologic malignancies. Cancer Chemother Pharmacol, v. 73, p. 875-883, 2014.

GERHART, J. From feedback inhibition to allostery: the enduring example of aspartate transcarbamoylase. FEBS Journal, v. 218, n. 1, p, 612-620, 2014.

GERVAIS, D.; FOOTE, N. Recombinant Deamidated Mutants of Erwinia chrysanthemi L-Asparaginase Have Similar or Increased Activity Compared to Wild-Type Enzyme. Mol Biotechnol, 2014.

GESTO, D.S. et al. Unraveling the enigmatic mechanism of L-asparaginase II with QM/QM calculations. JACS, v. 135, p. 7146-7158, 2013.

GOPAL, G.J.; KUMAR, A. Strategies for the Production of Recombinant Protein in Escherichia coli. Protein J, 2013.

HAMERSCHLAK, N. Leucemia: fatores prognósticos e genética. Jornal de Pediatria, v. 84, p. 52-57, 2008.

HERMANOVA, I. et al. Low expression of asparagine synthetase in lymphoid blasts precludes its role in sensitivity to L-asparaginase. Experimental Hematology, v. 40, n. 1, p. 657-665, 2012.

HOELZER, D. Personalized medicine in adult acute lymphoblastic leukemia. Haematologica, v. 100, n. 7, p. 855-858, 2015.

IMADA, A. et al. Asparaginase and Glutaminase Activities of Micro-organisms. Journal of General Microbiology, v. 76, p. 85-99, 1973.

INCA. Leucemia. Rio de Janeiro, 2014. Disponível em: $<$ http://www2.inca.gov.br/wps/wcm/connect/tiposdecancer/site/home/leucemia>. Acesso em: 25 jul 2015. 
JONES, G.E.; MORTIMER, R.K. Biochemical Properties of Yeast LAsparaginase. Biochemical Genetics, v. 9, n. 2, p. 131-146, 1973.

KARAMITROS, C.S. et al. Preserving Catalytic Activity and Enhancing Biochemical Stability of the Therapeutic Enzyme Asparaginase by Biocompatible Multilayered Polyelectrolyte Microcapsules. Biomacromolecules, v. 14, n. 1, p. 4398-4406, 2013.

KARAMITROS, C.S.; KONRAD, M. Human 60-kDa Lysophospholipase Contains an N-terminal L-Asparaginase Domain That Is Allosterically Regulated by L-Asparagine. The Journal of Biological Chemistry, v. 289, n. 19, p. 12662-12975, 2014.

KAWEDIA, J.D.; RYTTING, M.E. Asparaginase in Acute Lymphoblastic Leukemia. Clinical Lymphoma, Myeloma \& Leukemia, v. 14, n. S3, p. S14S17, 2014.

KIDD, J.G. Regression of transplanted lymphomas induced in vivo by means of normal guinea pig serum. The Journal of experimental medicine, v. 98, p. 583-605, 1953.

KOSHLAND, D.E.; HAMADANI, K. Proteomics and Models for Enzyme Cooperativity. The Journal of Biological Chemistry, v. 277, p. 46841-46844, 2002.

KOTZIA, G.A.; LABROU, N.E. L-Asparaginase from Erwinia Chrysanthemi 3937: Cloning, expression and characterization. Journal of Biotechnology, v. 127, p. 657-669, 2007.

KUMAR, K. et al. L -asparaginase: an eff ective agent in the treatment of acute lymphoblastic leukemia. Leukemia and Lymphoma, v. 55, n. 2, p. 256-262. 2014.

LAEMMLI, U. K. Cleavage of structural proteins during the assembly of the head of bacteriophage T4. Nature, v. 227, n. 1, p. 680-685, 1970.

LEUKIMIA AND LYMPHOMA SOCIETY. Facts Springs 2014. Nova York, 2014. Disponível em:

$<$ http://www.lls.org/content/nationalcontent/resourcecenter/freeeducationmateri als/generalcancer/pdf/facts.pdf>. Acesso em: 25 jul 2015.

LEBENDIKER, M.; DANIELI, T. Production of prone-to-aggregate proteins. FEBS, v. 588, p. 236-246, 2014.

MANUAL ALIGENT-TECHNOLOGIES. ArcticExpress Competent Cells and ArcticExpress (DE3) Competent Cells. p. 03-05, 2010.

MANUAL NOVAGEN. Cometent Cells. p. 03-06, 2004. 
MASHBURN, L.T.; WRISTON, J.C. Tumor Inhibitory Effect of L-asparaginase from Escherichia coli. Arch Biochem Biophys, v. 105, p. 450-452, 1964.

MICHALSKA, K.; JASKOLSKI, M. Structural aspects of I-asparaginases, their friends and relations. Acta Biochim Pol., v. 53, n. 4, p. 627-640, 2006.

MILLER, M. et al. A left-handed crossover involved in amidohydrolase catalysis Crystal structure of Erwinia chrysanthemi L-asparaginase with bound Laspartate. FEBS, v. 328, n. 3, p. 275-279, 1993.

\section{MINISTÉRIO DE SAUDE. Complexo Industrial - Brasil Amplia Produção de medicamentos Biológicos. 2013. Disponível em: $<$ http://www.bio.fiocruz.br/images/stories/pdfs/releases/release-gecis-junho- 2013-ascomms.pdf>. Acesso em: 27 jun 2014.}

NARAZAKI, $H$. et al. Delayed-type Hypersensitivity in Response to Lasparaginase in a Case of Acute Lymphoblastic Leukemia. J Nippon Med, v. 79, p. 489-493, 2012.

NARTA, U. K.; KANWAR, S. S.; AZMI, W. Pharmacological and clinical evaluation of I-asparaginase in the treatment of leukemia. Critical Reviews in Oncology/Hematology v. 61, p. 208-221, 2007.

NELSON, D.L.; COX, M. M. Princípios de Bioquímica de Lehninger. $5^{\circ}$ ed. Porto Alegre-RS: Artmed, 2011.153-227p.

OFFMAN, M. et al. Rational engineering of L-asparaginase reveals importance of dual activity for cancer cell toxicity. Blood Journal, v. 117, p. 1614-1621, 2011.

ORSONNEAU, J. L. et al. Automated kinetic assay of plasmatic L-asparaginase activity undergoing therapy for acute lymphoblastic leukemia. Annales de Biologie Clinique, v. 62, n. 5, p. 568-72. 2004.

PALM, G.J. et al. A covalently bound catalytic intermediate in Escherichia coli asparaginase: Crystal structure of a Thr-89-Val mutant. FEBS, v. 390, p. 211216, 1996.

PAPAGEORGIOU, A. C. et al. Structural and functional insights into Erwinia carotovora L-asparaginase. FEBS Journal, v. 275, n. 1, p. 4306-4316, 2008.

PARMENTIER, J. H. et al. Glutaminase activity determines cytotoxicity of Iasparaginases onmost leukemia cell lines. Leuk Res, v. 39, n. 7, p. 757-762, 2015.

PHILO, J.S.; ARAKAWA, T. Mechanisms of Protein Aggregation. Current Pharmaceutical Biotechnology, v. 10, p. 348-351, 2009.

PIETERS, R. et al. Pharmacokinetics, pharmacodynamics, efficacy, and safety of a new recombinant asparaginase preparation in children with previously 
untreated acute lymphoblastic leukemia: a randomized phase 2 clinical trial. Blood Journal, v. 112, p. 4832-4838, 2008.

PIETERS, R. et al. L-asparaginase treatment in acute lymphoblastic leukemia: a focus on Erwinia asparaginase". Cancer, v. 117, p. 238-249, 2011.

PRADHAN, B.; DASH, S.K.; SAHOO, S. Screening and characterization of extracelluar L-asparaginase producing Bacillus subtilis strain hswx88, isolated from Taptapani hotspring of Odisha, India. Asian Pac J Trop Biomed, v. 3, n. 12, p. 936-941, 2013.

RAETZ, E. A.; SALZER, W.L. Tolerability and Efficacy of L-Asparaginase Therapy in Pediatric Patients With Acute Lymphoblastic Leukemia. J Pediatr Hematol Oncol, v. 32, p. 554-563, 2010.

RICARD, J.; CORNISH-BOWDEN, A. Co-operative and allosteric enzymes: 20 years on. Eur. J. Biochem, v. 166, p. 255-272, 1987.

RIZZARI, C. et al. Optimizing asparaginase therapy for acute lymphoblastic leukemia. Co-oncology, v. 25, p. S1-S9, 2013.

ROBBINS, S.L.; KUMAR, V.; COTRAN, R.S. Patologia Estrutural e Funcional. $6^{\circ}$ ed. Rio de Janeiro-RJ: Guanabara Koogan, 2000. 589p.

ROBERTS, G.K.; MULLIGHAN, C.G. Genomics in acute lymphoblastic leukaemia: insights and treatment implications. Nature reviews: clinical oncology, v. 12, p. 344-357, 2015.

SANCHES, M.; KRAUCHENCO, S.; POLIKARPOV, I. Structure, Substrate Complexation and Reaction Mechanism of Bacterial Asparaginases. Current Chemcial Biology, v. 1, n. 12, p. 75-86, 2007

SCHWARTZ, J.H.; REEVES, J.Y.; BROOME, J.D. Two L-Asparaginases from E. coli and their action against tumor. Proc Natl Acad Sci U S A, v. 56, n, 5, p. 1516-1519, 1966.

SHRIVASTAVA, A. et al. Recent developments in L-Asparaginase discovery and its potential as anticancer agent. Oncology Hematology, p. 1-12, 2015.

SILVA, F. A. Avaliação epidemiológica das leucemias linfoblásticas em crianças brasileiras e implicação de infecções na sua patogênese. 2009. Tese de doutorado - Instituto Nacional de câncer, 2009. Disponível em:

$<$ http://bvsms.saude.gov.br/bvs/publicacoes/inca/Avaliacao_epidemiologica_da s_leucemias_linfoblasticas_em_(1).pdf>. Acesso em: 29 junho 2014

SINCLAR, K.; WARNER, J.P.; BONTHRON, D.T. The ASP1 gene Saccharomyces cerevisiae, encoding the intracelular isozyme of Lasparaginase. Gene, v. 144, p. 37-43, 1994.

SWAIN, A.L. et al. Crystal structure of Escherichia coli L-asparaginase, an enzyme used in cancer therapy. PNAS, v. 90, p. 1472-1478, 1993. 
VERMA, N. et al. L-Asparaginase: A Promising Chemotherapeutic Agent. Critical Reviews in Biotechnology, v. 27, p. 45-62, 2007.

YAO, M. et al. Structure of the type I I-asparaginase from the hyperthermophilic archaeon Pyrococcus horikoshii at 2,6Å resolution. Acta. Cryst., v. D61, p. 294301, 2005.

YUN, M. et al. Crystal Structure and Allosteric Regulation of the Cytoplasmic Escherichia coli L-Asparaginase I. J. Mol. Biol., v. 369, p. 794-811, 2007.

WORLD HEALTH ORGANIZATION. Incidence of childhood leukaemia. ENHIS, Europa, 2009. Disponível em:

$<$ http://www.euro.who.int/_data/assets/pdf_file/0005/97016/4.1.-Incidence-ofchildhood-leukaemia-EDITED_layouted.pdf> . Acesso em: 25 jul 2015. 
ANEXO A - Mapa do vetor de expressão pET15b (Novagen Merck -

Millipore).

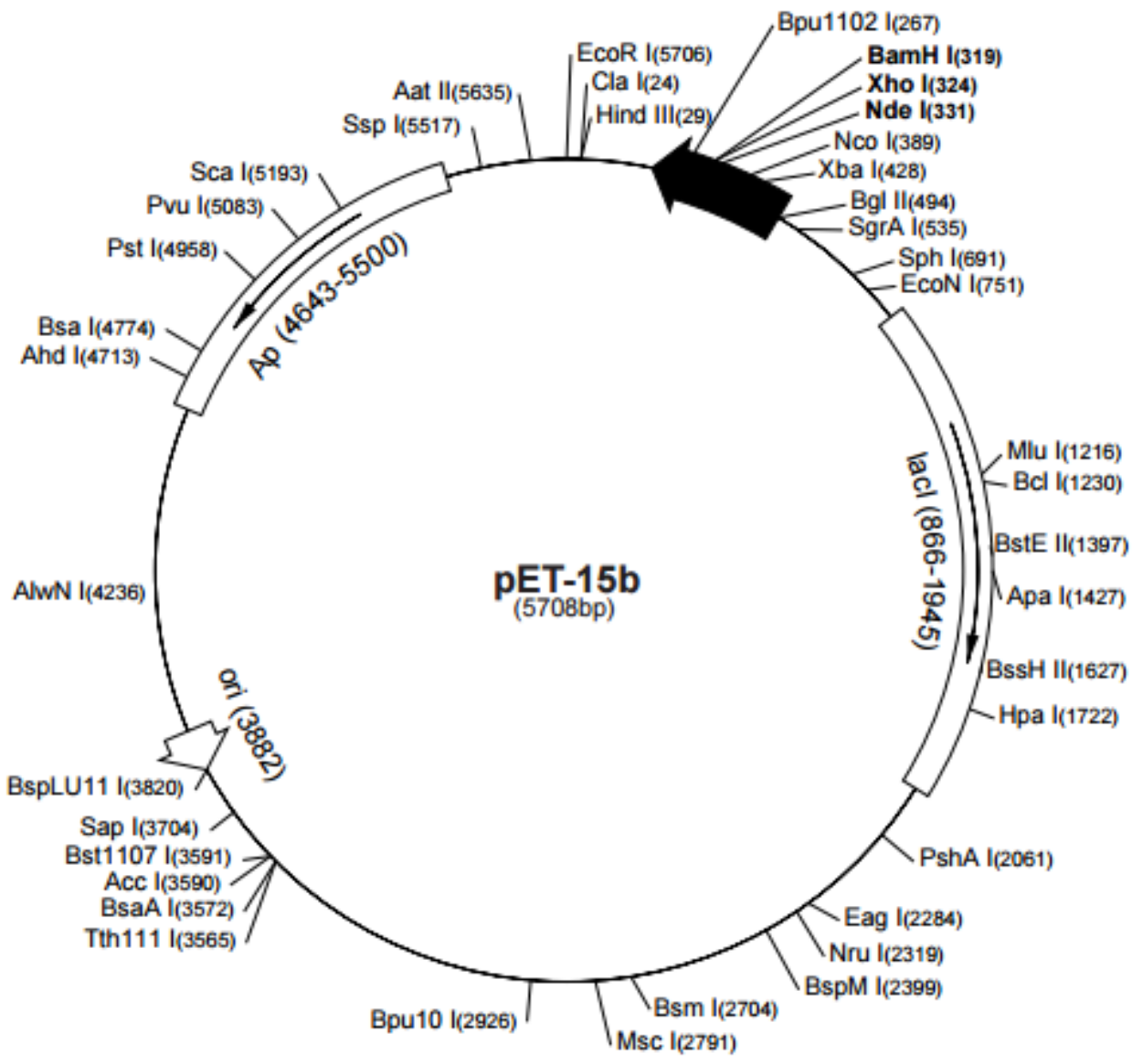

\section{T7 promoter primer $469348 \cdot 3$}

$\underline{B g}$ ill

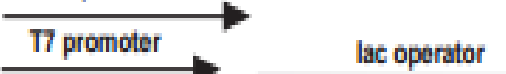
$\underline{X b a 1}$

rbs

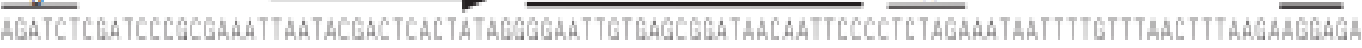

\section{Neol \\ His*Tag \\ Ndel Xhol Banth I}

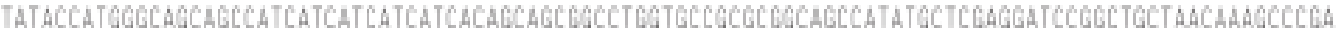

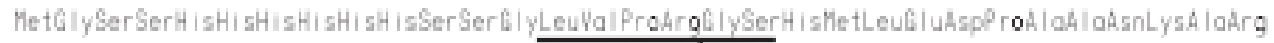

$$
\text { Bpul1021 } \text { thrombin }^{1} \text { T7 terminator }
$$

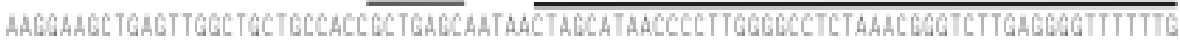

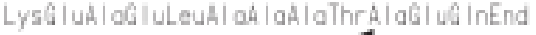

77 teminator primer 469337.3 
ANEXO B - Atividade específica para L-asparagina e L-glutamina e cinética daASPasell (Prospec-Tany).

A

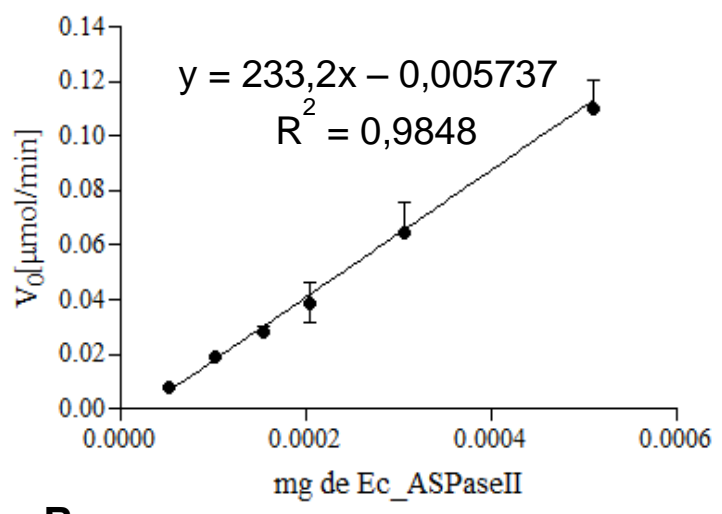

B

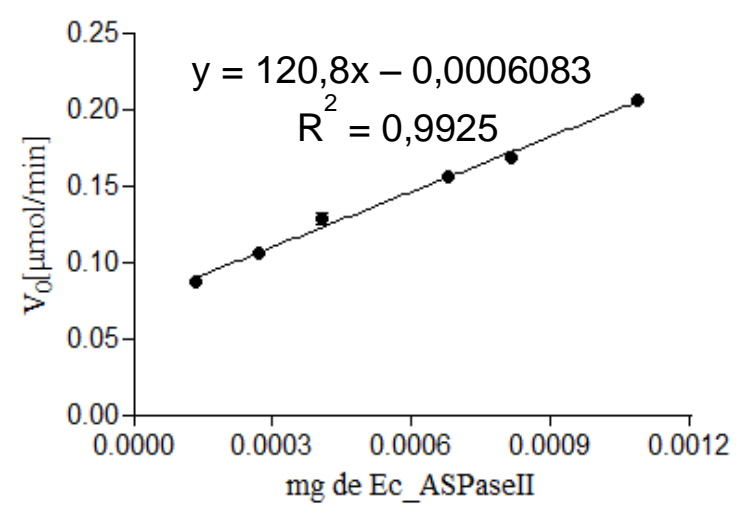

C

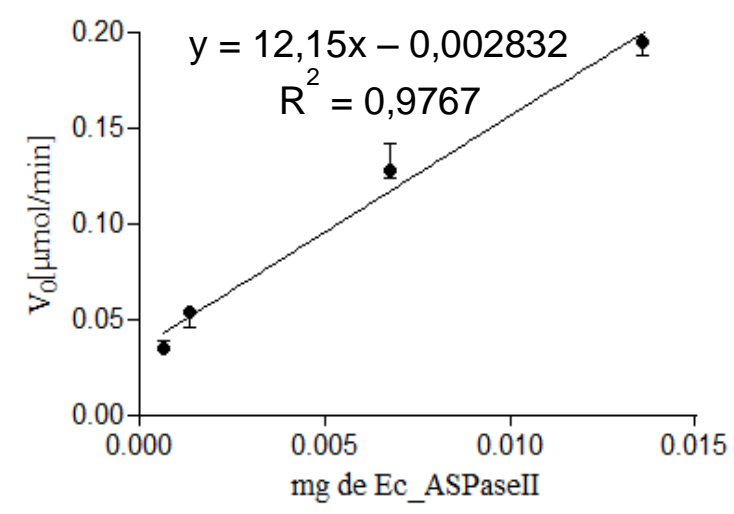

D

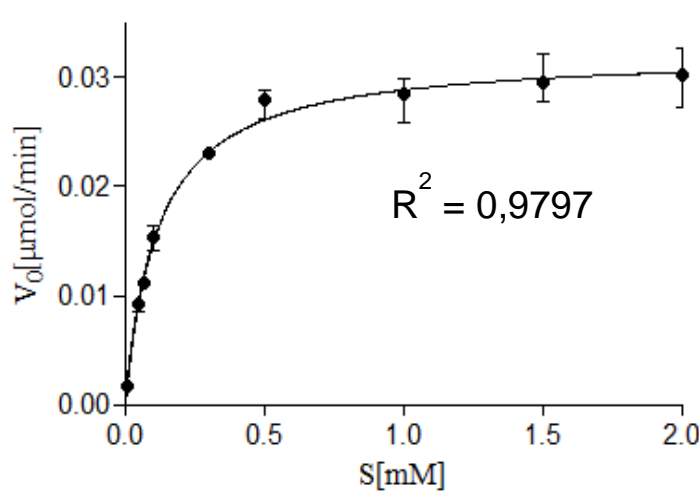

$E$

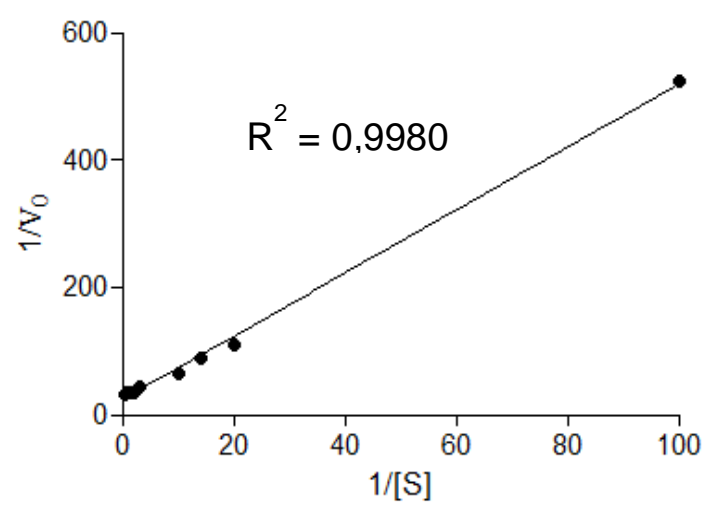

Gráfico da reação de velocidade inicial em função da quantidade em mg de proteína purificada utilizada no ensaio. A: Gráfico da atividade específica para L-asparagina determinada pelo reagente de Nessler. B: Gráfico da atividade específica para L-asparagina determinada pelo ensaio acoplado ao consumo de NADH. C: Gráfico da atividade específica para L-glutamina determinada pelo ensaio acoplado ao consumo de NADH D: Gráfico de Michaelis-Mentes da cinética enzimática obtido por regressão não linear. E: Gráfico de Lineweaver-Burk obtido a partir dos dados plotados em C. Os pontos representam a média \pm desvio padrão $(n=3)$. O coeficiente angular da equação de reta representa a atividade em $\mathrm{U} / \mathrm{mg}$ de proteína. Os gráficos e a determinação das atividades foram obtidas por meio do programa GraphPad Prism v.5.0. 
ANEXO C - Gráficos da atividade específica e cinética dos mutantes A331D, K335E, $\Delta$ G77, S301N e Y243S.

- Atividade específica:
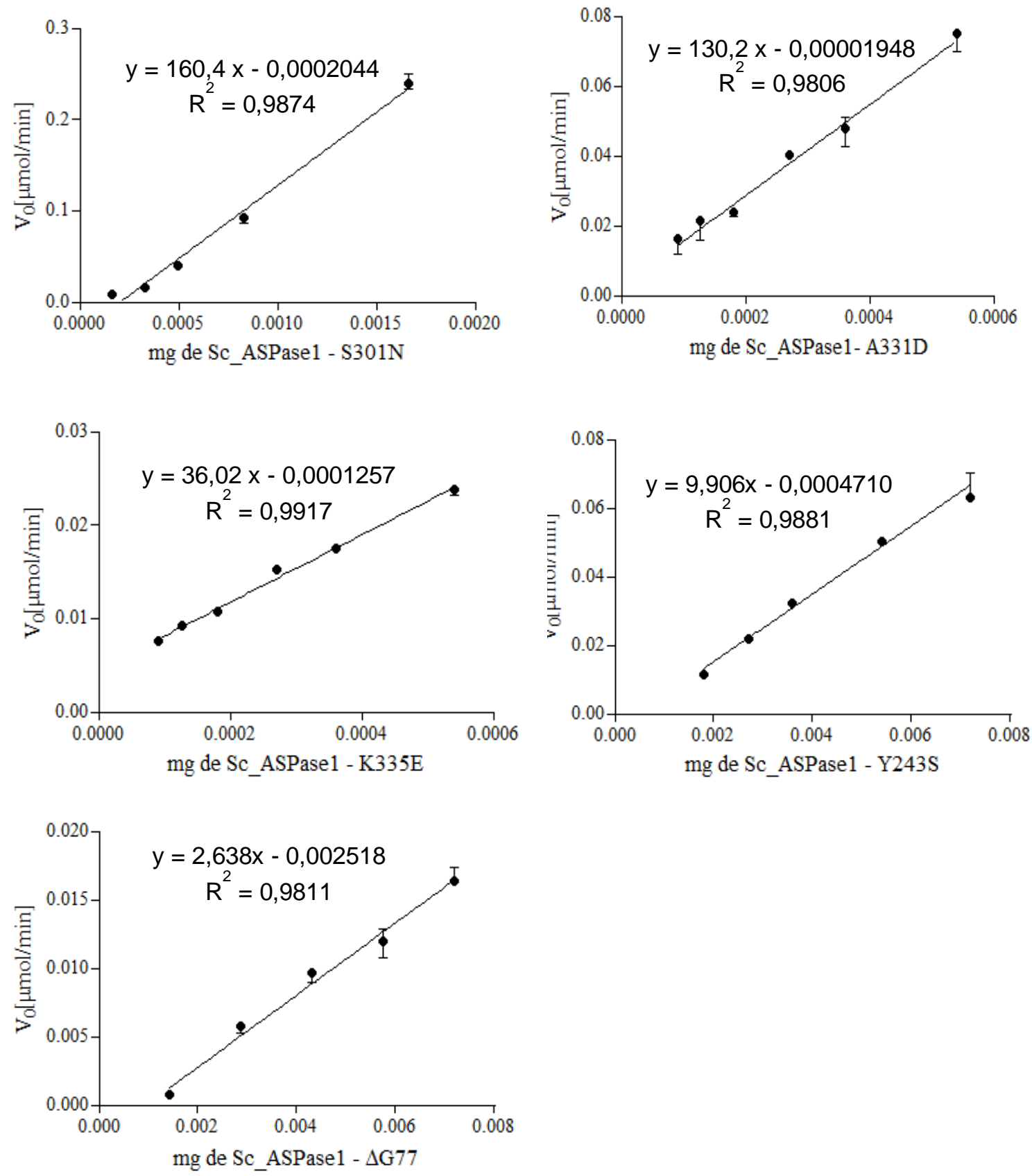

Gráfico da reação de velocidade inicial em função da quantidade em mg de proteína purificada utilizada no ensaio. Gráfico da atividade específica para L-asparagina para as isoformas mutantes A331D, S301N, K335E, $\Delta \mathrm{G} 77$ e Y243S. Os pontos representam a média \pm desvio padrão $(n=3)$. O coeficiente angular da equação de reta representa a atividade em U/mg de proteína. Os gráficos e a determinação das atividades foram obtidas com programa GraphPad Prism v.5.0. 
- Gráfico da cinética e de Hill representado por $\mathbf{A}$ e $\mathbf{B}$, respectivamente:

Mutante A331D

A

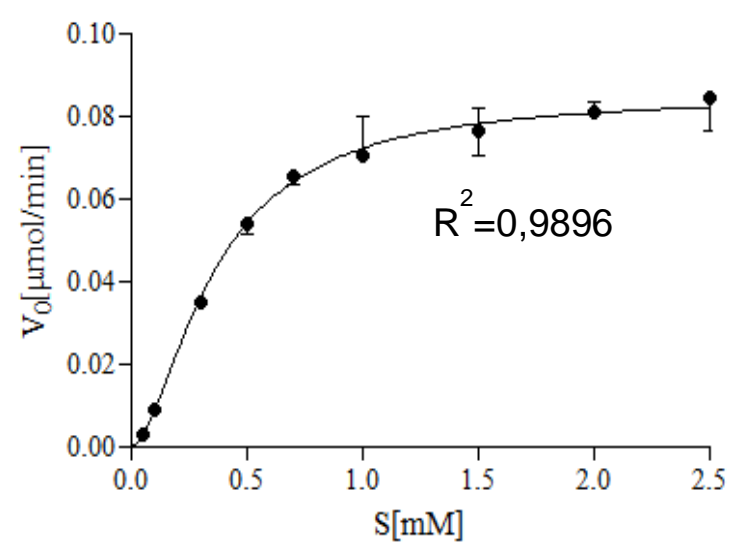

Mutante K335E

A

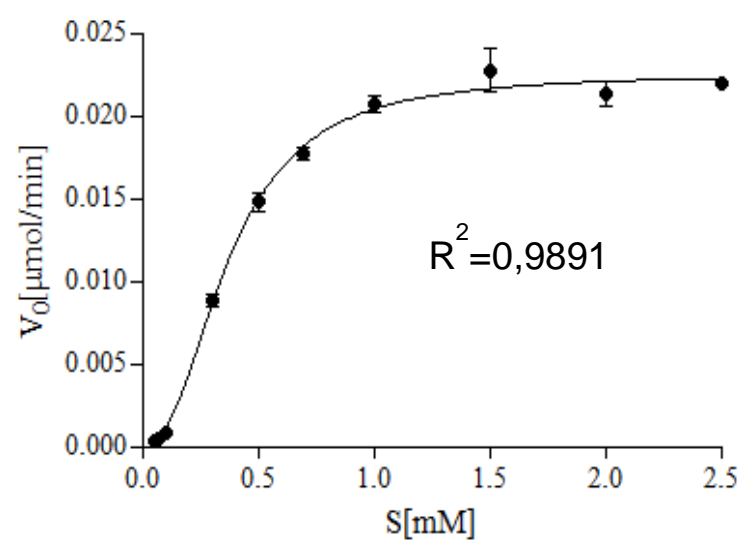

Mutante S301N

A

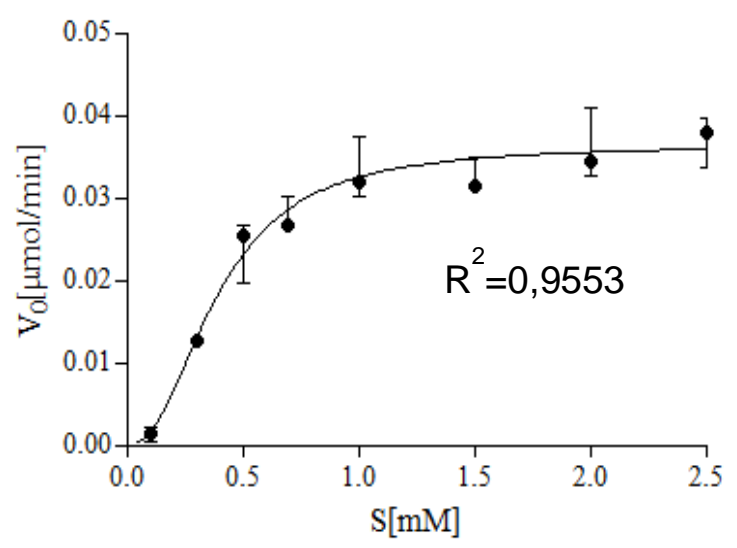

B

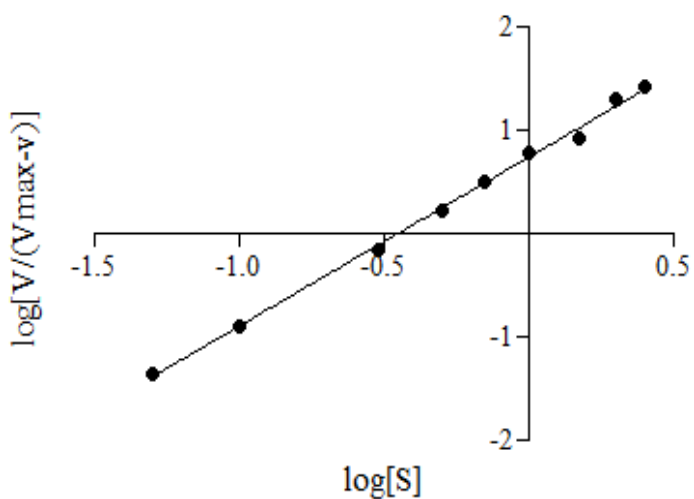

B

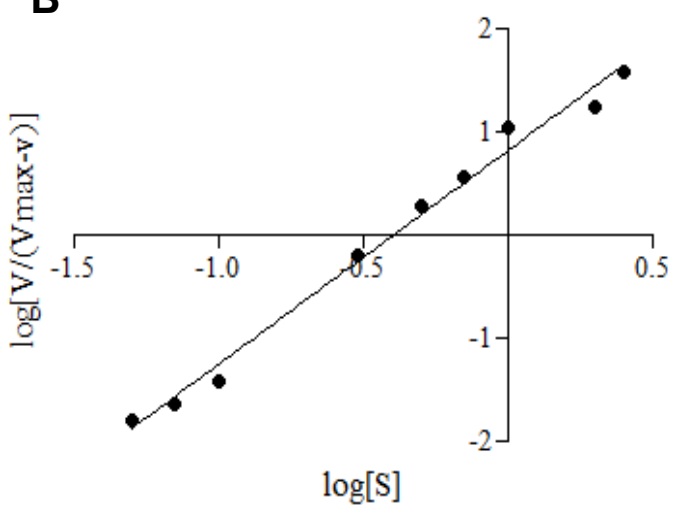

B

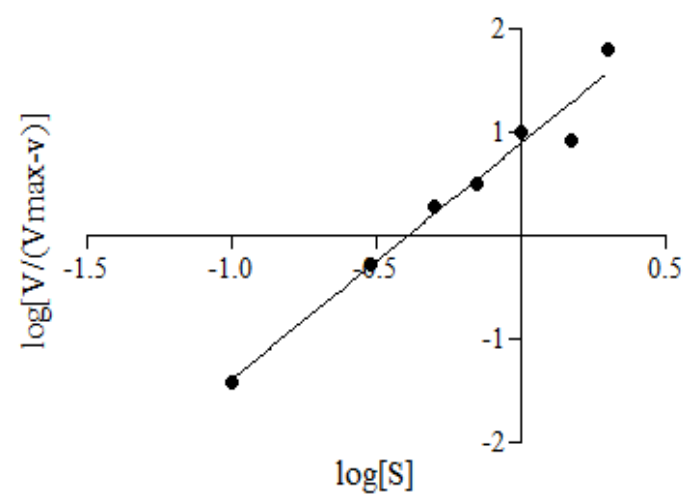

Gráfico da reação de velocidade inicial em função da concentração de L-asparagina dos mutantes A331D, K335E, $\triangle$ G77, S301N e Y243S. A: Gráfico alostérico sigmoidal da cinética enzimática. B: Gráfico de Hill. Os pontos representam a média \pm desvio padrão $(n=3)$. Os gráficos foram obtidas com o programa GraphPad Prism v.5.0. 